\title{
Acylboronates in Polarity-Reversed Generation of Acyl Palladium(II) Intermediates
}

\author{
Alina Trofimova, ${ }^{\dagger}$ Aleksandra Holownia, ${ }^{\dagger}$ Chieh-Hung Tien, \\ Martynas J. Širvinskas, and Andrei K. Yudin*
}

Davenport Research Laboratories, Department of Chemistry, University of Toronto, 80 St. George Street, Toronto, ON, M5S 3H6, Canada

${ }^{\dagger}$ These authors contributed equally

Abstract: We report a catalytic cross-coupling process between aryl (pseudo)halides and boronbased acyl anion equivalents. This mode of acylboronate reactivity represents polarity reversal, which is supported by the observation of tetracoordinated boronate and acyl palladium(II) species by ${ }^{11} \mathrm{~B},{ }^{31} \mathrm{P} N \mathrm{NMR}$, and mass spectrometry. A broad scope of aliphatic and aromatic acylboronates has been examined, as well as a variety of aryl (pseudo)halides.

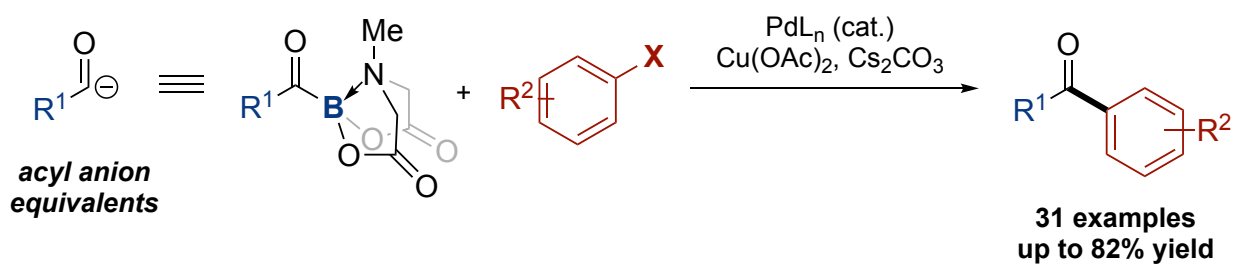

\section{Introduction:}

Polarity reversal (umpolung) allows one to switch the natural polarization of a functional group. ${ }^{1}$ A number of established examples of this phenomenon demonstrate how electrophilic functional groups can be turned into nucleophiles and vice versa. Carbonyl compounds, which are electrophiles of prominence in organic synthesis, react with a broad range of nucleophilic species. $^{2}$ An umpolung transformation can reverse polarization such that the carbonyl functionality is made to react with electrophiles as an acyl or formyl anion. ${ }^{2}$

Acylboron compounds, which are a class of functionalized carbonyl group-containing molecules, have emerged as useful reagents in organic synthesis. ${ }^{3,4}$ While effective as boroncontaining building blocks, these molecules are not stable in their free boronic acid form. ${ }^{5}$ Synthetic applications of acylboronates are enabled by the utilization of a MIDA ( $N$ methyliminodiacetic acid) ligand ${ }^{4 c-g, 7}$ or potassium organotrifluoroborates, ${ }^{4 a, b, g, h}$ which provide enhanced stability to borylated compounds. It is now well understood that acylboronates display reactivity that is similar to the ketone functionality. ${ }^{8}$ The ability of acylboronates to undergo nucleophilic addition has found application in the synthesis of valuable boron-containing heterocycles, peptides, and proteins (Scheme 1a). ${ }^{4,8} \alpha$-Functionalization of acylboronates reveals another mode of reactivity, further underscoring the relative stability of BMIDA under a range of reaction conditions. ${ }^{4 \mathrm{f}, 8 \mathrm{c}}$ Acylboronates have shown to participate in rearrangement reactions yielding $\mathrm{N}_{-}, \mathrm{O}-$, and $\mathrm{C}$-borylated species that are difficult to prepare by alternate routes as a result of boron atom migration. ${ }^{8 d}$ After derivatization, the MIDA ligand can be removed, ${ }^{7}$ leading to the 
isolation of stable molecules in free boronic acid form or non-borylated compounds afforded by rapid protodeboronation. ${ }^{9}$

While there are numerous reports on the electrophilic reactivity of acylboronates, a polarityreversed application in catalyst has not been realized to date. ${ }^{10}$ Herein, we report that readily available MIDA acylboronates ${ }^{4 \mathrm{~g}}$ give rise to boron analogs of $\alpha$-keto acids. The boron-based acyl anion equivalents have been evaluated in the Pd-catalyzed Suzuki-Miyaura reaction of acylboronates and aryl (pseudo)halides in the construction of $C\left(\mathrm{sp}^{2}\right)-C\left(\mathrm{sp}^{2}\right)$ bonds (Scheme $1 \mathrm{~b}$ ). The observation of tetracoordinated boronate and acyl palladium(II) intermediates provides additional insights into transmetalation in the Suzuki-Miyaura reaction and complements the previously published reports about this least understood step of the catalytic cycle. ${ }^{11} \mathrm{~A}$ broad scope of aryl (pseudo)halides has been investigated, as well as a number of aryl and alkyl acylboronates.

A. Electrophilic Reactivity of MIDA Acylboronates
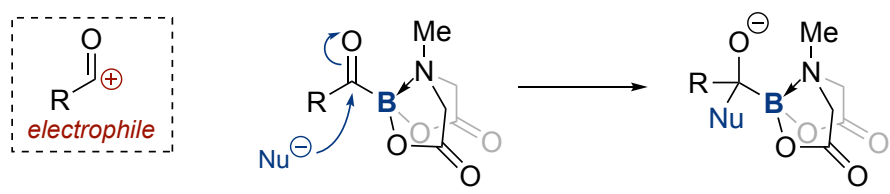

B. This work
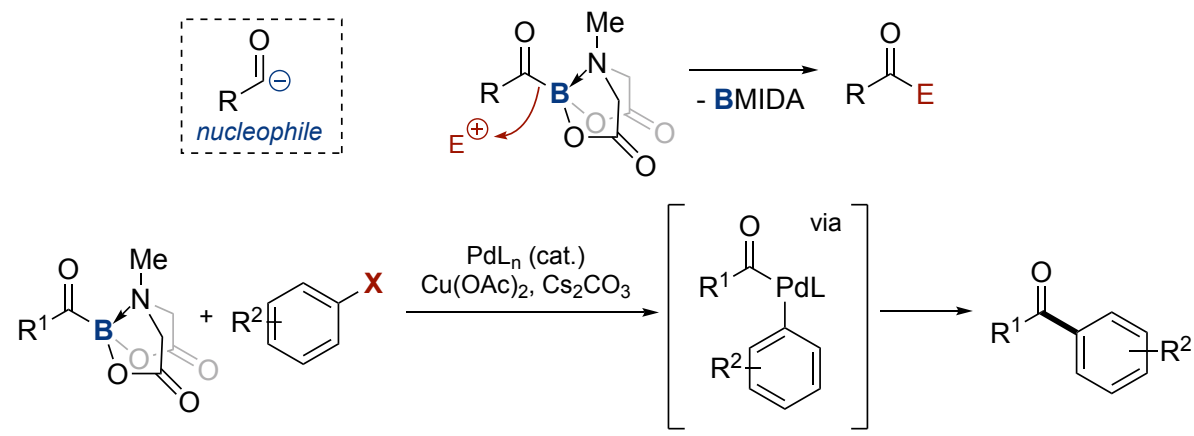

Scheme 1: a) Previous work on electrophilic reactivity of MIDA acylboronates; b) This work: Pd-catalyzed SuzukiMiyaura cross-coupling reaction of acylboronates as acyl anion equivalents.

\section{Results and Discussion:}

We hypothesized that the polarity-reversed application of acylboronates could be examined in the Pd-catalyzed cross-coupling reaction of aryl halides. As a model reaction for our initial investigations, acylboronate $1 \mathrm{a}$ and $p$-iodoanisole were combined with catalytic XPhos Pd G2, $\mathrm{Cu}(\mathrm{OAc})_{2}$ as the stoichiometric additive, and $\mathrm{K}_{2} \mathrm{CO}_{3}$ as a base in 4:1 solvent mixture of DMF:tertamyl alcohol ( $t$-amylOH). The reaction afforded the desired ketone product $3 a$ in $44 \%$ yield (Table 1 , entry 1 ). Analysis of the crude reaction mixture by ${ }^{1} \mathrm{H}$ NMR and GC-MS revealed the major sideproduct of the reaction to be benzaldehyde $4 a$, owing to the protodeboronation of $1 \mathrm{a}$. Other sideproducts observed were products of aryl iodide homocoupling, deiodination, and decarbonylative cross-coupling. To optimize the reaction conditions, solvent, palladium species, base, additive, and temperature were screened. Switching $t$-amylOH to IPA led to lower yields of 3a (Entry 2), but omitting alcoholic co-solvent resulted in a slight increase in yield (Entry 3). Changing $p$-iodoanisole to $p$-bromoanisole did not have a major impact on the yield but limited the formation of other side-products, such as biaryl derivatives to $<10 \%$, which aids purification 
(Entry 4). Other solvents, such as MeCN, toluene, and dioxane were ineffective, likely due to the reduced solubility of $1 \mathrm{a}$ (Entries $5-7$ ). Switching the stoichiometric additive to $\mathrm{CuCl}$ and $\mathrm{Cul}$, or decreasing the equivalents of $\mathrm{Cu}(\mathrm{OAc})_{2}$ had a negative impact on the reaction (Entries $8-10$ ). Other Pd species were inferior compared to XPhos Pd G2 (Entries 11 - 14). Increasing the temperature of the reaction to $100^{\circ} \mathrm{C}$ also decreased the yield of $3 a$ (Entry 15). While $\mathrm{K}_{3} \mathrm{PO}_{4}$ was found to be a less efficient base (Entry 16$), \mathrm{Cs}_{2} \mathrm{CO}_{3}$ was significantly more effective (Entry 17). Decreasing the reaction temperature to $60^{\circ} \mathrm{C}$ led to the formation of $3 a$ in $73 \%$ yield (Entry 18).

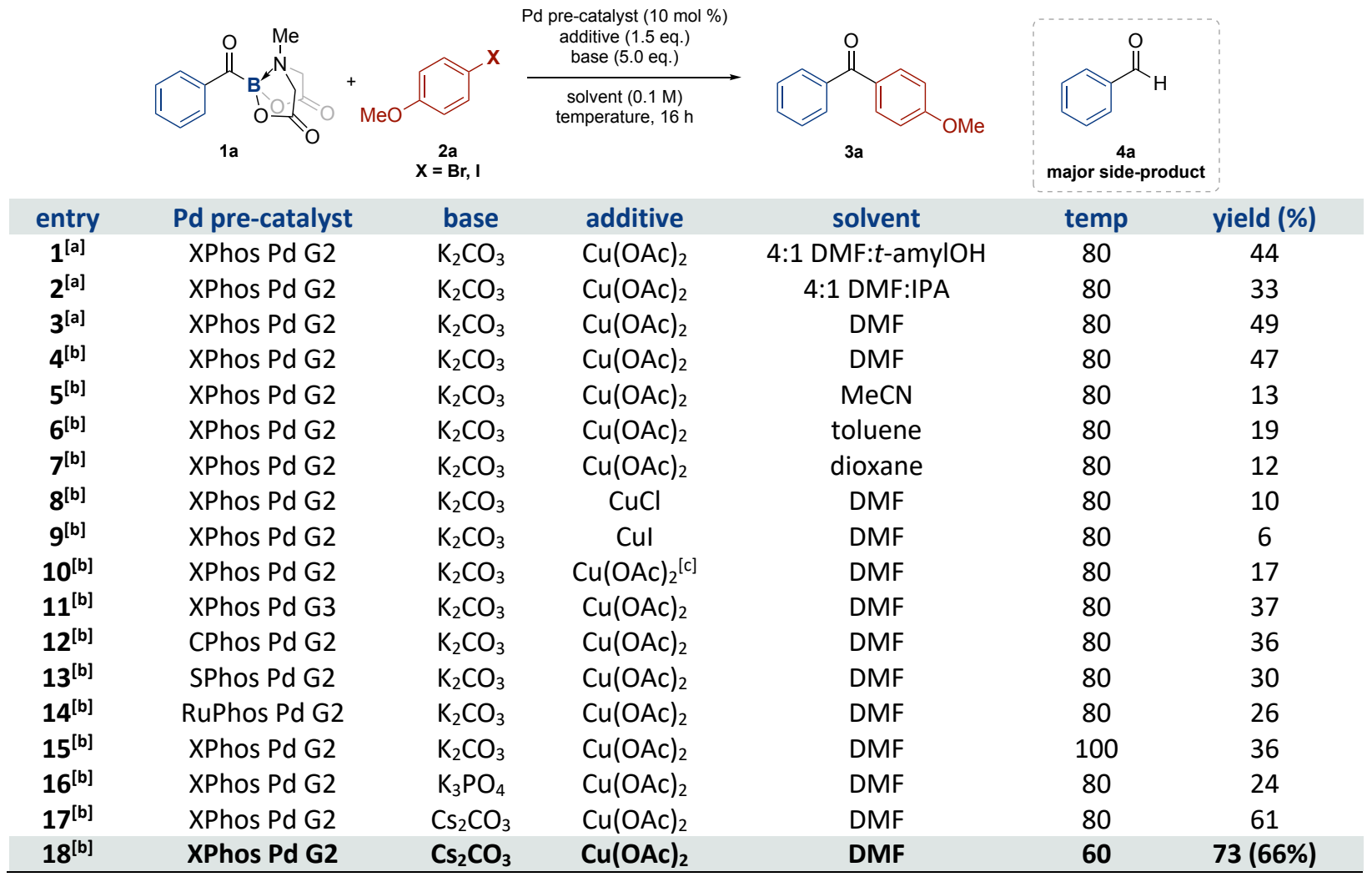

Table 1. The Suzuki-Miyaura reaction optimization. Reaction conditions: 1a (1.5 eq.), Pd pre-catalyst (10 mol \%), additive (1.5 eq.) and base (5.0 eq.) were combined in a flame-dried 0.5-dram vial under nitrogen atmosphere. Solvent $(0.1 \mathrm{M})$ was added followed by $p$-bromo- or iodoanisole $(0.05 \mathrm{mmol}, 1.0 \mathrm{eq}$.). The reaction was capped and stirred for 16 hours at the indicated temperature. Production of 3a was referenced to 1,3,5-trimethoxybenzene and the NMR yield was calculated accordingly. ${ }^{b}$ Reactions were carried out with $p$-iodoanisole. ${ }^{c}$ Reactions were carried out with $p$-bromoanisole. ${ }^{d} 0.75$ eq. was used.

The scope of the reaction was explored with respect to aryl bromide utilizing the optimized reaction conditions (Scheme 2). para-, meta-, and ortho-Bromoanisole were employed in the transformation to afford the corresponding ketones $\mathbf{3 a - 3 c}$ in good yield. The position of the substituent on the aromatic ring of aryl bromide did not have a significant influence on the reaction outcome. Notably, the reaction producing 3a was successfully scaled up to $1 \mathrm{mmol}$ under standard conditions. The amine functional group was tolerated in the reaction (3d). An arene with increased electron density was a suitable coupling partner and led to product formation in a good yield (3e). Reactions with mono-, di-, and tri-methylated aryl bromides provided ketones $\mathbf{3 f - i}$ in moderate yields. Ketones $\mathbf{3 j}$ and $\mathbf{3 k}$ were synthesized in $56 \%$ and $43 \%$ yield, respectively. The use 
of $p$-bromochlorobenzene afforded the corresponding ketone 31 in 38\%, showing that aryl bromides were more reactive in the transformation than aryl chlorides. In general, substrates bearing electron-donating groups reacted more efficiently in the cross-coupling reaction, whereas the presence of electron-withdrawing groups, such as trifluoromethyl (3m), cyclic ketone $(3 n)$, benzothiophene (3o), and methoxypyridine (3p) on the arene resulted in lower yields of the corresponding ketone products. Pyridyl and methylthiophene were not compatible under the reaction conditions and provided only a trace amount of the corresponding ketones ( $\mathbf{3 q}$ and $\mathbf{3 r}$ ).

Next, we investigated the scope of electrophilic partners. The reaction of iodobenzene afforded the desired ketone $\mathbf{3} \mathbf{j}$ in higher yield compared to the reaction of bromobenzene, albeit with more side-product formation. The same ketone was synthesized in $29 \%$ assay yield when phenyl trifluoromethanesulfonate was used. Only a trace amount of $\mathbf{3} \mathbf{j}$ was observed when chlorobenzene was used due to the relative difficulty of oxidative addition into the $\mathrm{C}-\mathrm{Cl}$ bond.

Scope of Aryl Bromides with $1 a^{a}$
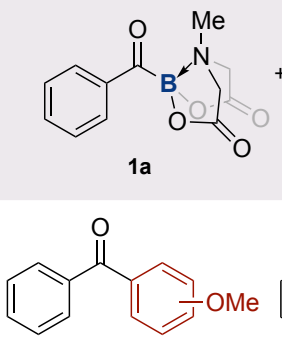

$3 a=p, 66 \%(64 \%)^{b}$ $3 \mathrm{~b}=m, 61 \%$ $3 c=0,59 \%$<smiles>Cc1cc(C)cc(C(=O)c2ccccc2)c1</smiles><smiles>O=C(c1ccccc1)c1ccc(Cl)cc1</smiles>

3I

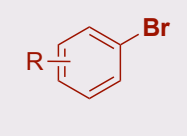

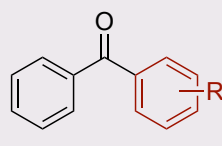

3a-r

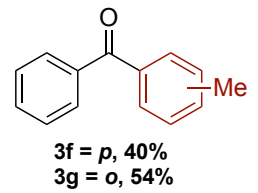

$3 \mathrm{~g}=0,54 \%$

$\mathrm{Cu}(\mathrm{OAc})_{2}$ (1.5 eq.)

DMF $(0.1 \mathrm{M})$
$60^{\circ} \mathrm{C}, 16 \mathrm{~h}$<smiles>COc1ccc(C(=O)c2ccccc2)cc1OC</smiles><smiles>O=C(c1ccccc1)c1ccc2ccccc2c1</smiles>

3<smiles>O=C(c1ccccc1)c1ccccc1</smiles>

$\stackrel{3 j}{(58 \%)^{c}}$

$3 k$
$43 \%$<smiles>O=C(c1ccccc1)c1ccc(C(=O)c2ccc3c(c2)C(=O)CC3)cc1</smiles>

$3 n$
$31 \%$

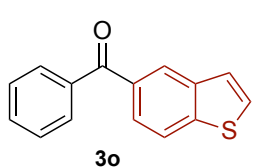

$65 \%$

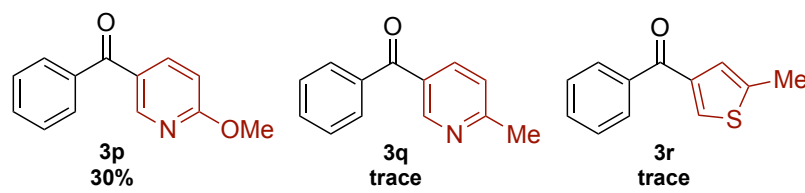

Scope of Aryl (Pseudo)Halides ${ }^{c}$

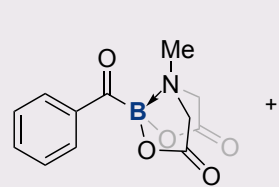

$1 a$

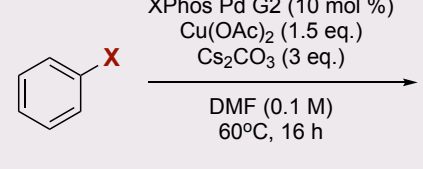

2

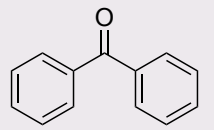

3j

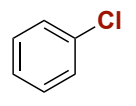

yield of $3 \mathbf{j}$

$6 \%$ 
Scheme 2. Scope of the Pd-catalyzed Suzuki-Miyaura reaction of MIDA acylboronate 1a with aryl bromides. Yields refer to the isolated product. ${ }^{a}$ Reactions were performed on a $0.1 \mathrm{mmol}$ scale using $1 \mathrm{1a}$ (1.5 eq.), aryl bromide (1.0 eq.), XPhos Pd G2 (10 mol \%), $\mathrm{Cu}(\mathrm{OAc})_{2}$ (1.5 eq.), $\mathrm{Cs}_{2} \mathrm{CO}_{3}$ (3.0 eq.) in DMF $(0.1 \mathrm{M}), 60^{\circ} \mathrm{C}, 16 \mathrm{~h} .{ }^{b}$ Performed on a 1 mmol scale under standard conditions. ${ }^{c} \mathrm{NMR}$ yield was determined by using 1,3,5-trimethoxybenzene as an internal standard.

The compatibility of other acylboronates to the cross-coupling conditions was also evaluated (Scheme 3). The introduction of an electron-withdrawing group, such as fluorine, to the aromatic ring of acylboronate resulted in successful reactions with $p$-bromoanisole and $p$-bromo- $N, N$ dimethylaniline (3s and $3 t$ ). The reactions of $p$-methoxybenzoyl boronate with the same aryl halides afforded the corresponding ketones $3 u$ and $3 v$ in $74 \%$ and $60 \%$ yield, respectively. We next investigated the compatibility of aliphatic acylboronates in the cross-coupling reaction. Gratifyingly, when acetyl boronate was employed as the nucleophilic partner, the reactions were successful and provided the desired ketones $\mathbf{3 w}$ and $\mathbf{3 x}$. The reaction of cyclohexanecarbonyl boronate gave the product (3y) in good yield. Ketones $\mathbf{3 z}$ and 3 aa were synthesized in $41 \%$ and $17 \%$ yield, respectively, in the reaction with 3-phenylpropanoyl boronate. The reaction of phenylacetyl boronate provided only trace amount of the desired ketone $3 a b$.

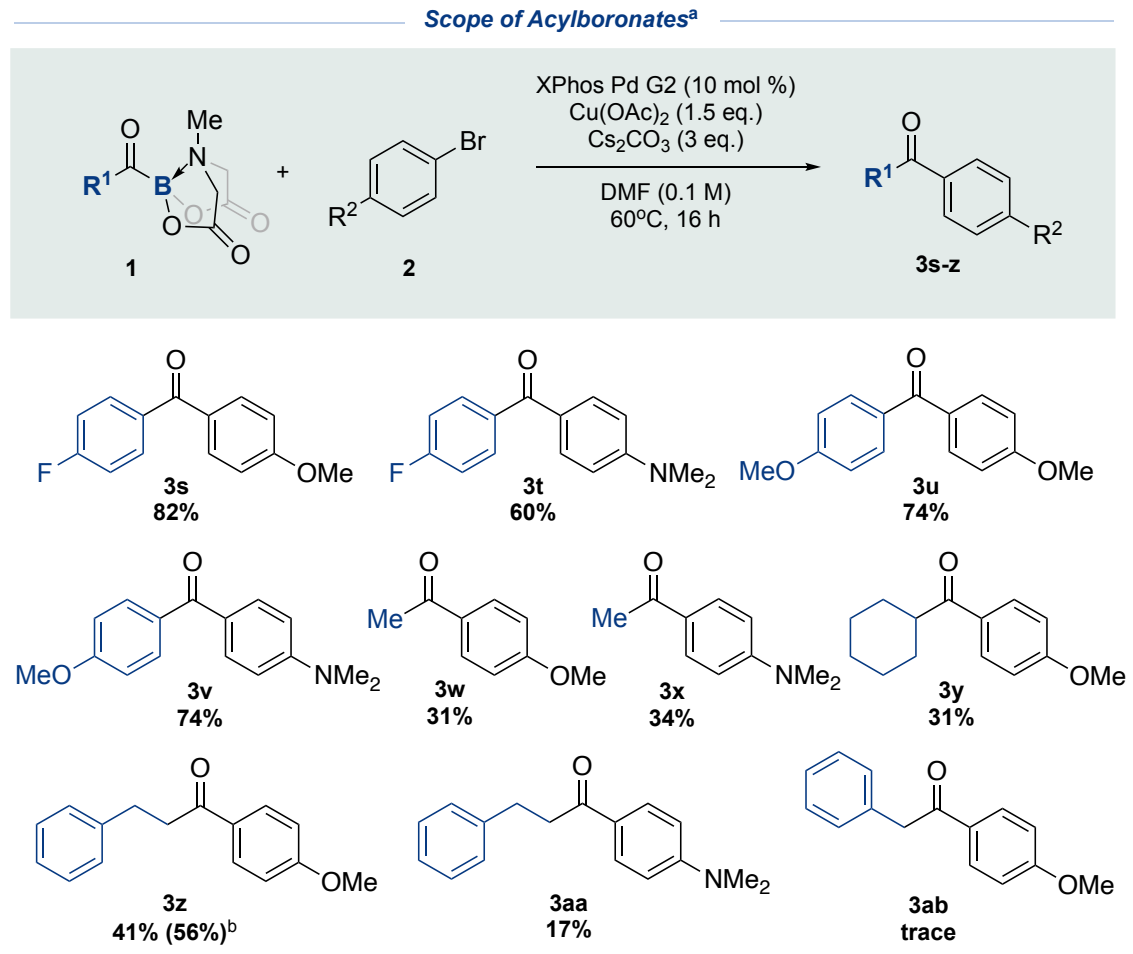

Scheme 3. Scope of the Pd-catalyzed Suzuki-Miyaura reaction of MIDA acylboronate 1 with aryl bromides. Yields refer to the isolated product. ${ }^{a}$ Reactions were performed on a $0.1 \mathrm{mmol}$ scale using 1 (1.5 eq.), aryl bromide (1.0 eq.), XPhos Pd G2 (10 mol \%), $\mathrm{Cu}(\mathrm{OAc})_{2}$ (1.5 eq.), $\mathrm{Cs}_{2} \mathrm{CO}_{3}$ (3.0 eq.) in DMF (0.1 M), 60 ${ }^{\circ} \mathrm{C}, 16 \mathrm{~h} .{ }^{b} \mathrm{NMR}$ yield was determined by using 1,3,5-trimethoxybenzene as an internal standard.

In order to gain insight into the mechanism of the reaction and identify possible intermediates, analysis by in situ NMR spectroscopy was employed. Due to the poor solubility of $\mathrm{Cs}_{2} \mathrm{CO}_{3}$ and the formation of insoluble by-products, the reaction of $1 \mathbf{1 a}$ and $2 \mathrm{a}$ in DMF- $d_{7}$ under standard conditions was not homogeneous and signals of the ${ }^{1} \mathrm{H}$ NMR spectrum were too broad to be 
analyzed quantitatively and qualitatively. Instead, a series of control reactions was conducted and monitored by ${ }^{11} \mathrm{~B}$ NMR spectroscopy. The reaction of $1 \mathrm{a}$ and $\mathbf{2 a}$ under standard conditions in DMF was monitored over 17 hours (Table 2, entry 1 ). After 1 hour, a ${ }^{11}$ B NMR spectrum consisted of a signal at $5.5 \mathrm{ppm}$ corresponding to $1 \mathrm{a}$ and a new resonance at $0.47 \mathrm{ppm}$. The intensity of the latter continued to rise over the course of the reaction, accompanied by the disappearance of the resonance of $1 \mathrm{a}$ within 11 hours. When 1a was mixed with 1.5 equivalents of $\mathrm{Cu}(\mathrm{OAc})_{2}$ and 3.0 equivalents of $\mathrm{Cs}_{2} \mathrm{CO}_{3}$ in $\mathrm{DMF}$ at $60^{\circ} \mathrm{C}$ in the absence of $\mathrm{Pd}$ catalyst, the same signal at $0.47 \mathrm{ppm}$ in the ${ }^{11} \mathrm{~B} N M R$ spectrum was observed (Entry 2). Further analysis was required to probe the intermediacy of the species with the distinct resonance at $0.47 \mathrm{ppm}$ that appeared in the course of both control reactions.

\begin{tabular}{ccc} 
entry & $\begin{array}{c}\text { deviation from standard } \\
\text { conditions }\end{array}$ & ${ }^{\mathrm{a}} \mathrm{B}$ BMR resonances \\
\hline $\mathbf{1}$ & none & $0.47 \mathrm{ppm}$ \\
$\mathbf{2}$ & no XPhos $\mathrm{Pd} \mathrm{G2}$, no $2 \mathrm{a}$ & $0.47 \mathrm{ppm}$ \\
$\mathbf{3}$ & no $\mathrm{Cu}(\mathrm{OAc})_{2}$ & no conversion \\
$\mathbf{4}$ & only $1 \mathrm{a}$ and $\mathrm{Cu}(\mathrm{OAc})_{2}$ & no conversion \\
$\mathbf{5}$ & only $1 \mathrm{a}$ and $\mathrm{Cs}_{2} \mathrm{CO}_{3}$ & no conversion \\
$\mathbf{6}$ & only $1 \mathrm{a}$ and $\mathrm{CsOAc}$ & no conversion \\
$\mathbf{7}$ & only $\mathbf{1 a}, \mathrm{Cu}(\mathrm{OAc})_{2}$, and $\mathrm{CsOAc}$ & no conversion
\end{tabular}

Table 2. Control reactions monitored by ${ }^{11} \mathrm{~B}$ NMR spectroscopy. ${ }^{\mathrm{a}}$ Standard conditions: $1 \mathrm{a}$ (1.5 eq.), aryl bromide (1.0 eq.), XPhos Pd G2 (10 mol \%), $\mathrm{Cu}(\mathrm{OAc})_{2}$ (1.5 eq.), $\mathrm{Cs}_{2} \mathrm{CO}_{3}$ (3.0 eq.) in $\mathrm{DMF}(0.1 \mathrm{M}), 60^{\circ} \mathrm{C}, 16 \mathrm{~h}$.

Additional control reactions were performed to get a better understanding of the reaction mechanism. No conversion of 1a was observed by ${ }^{11} \mathrm{~B} N \mathrm{NM}$ spectrometry when the reaction was conducted without $\mathrm{Cu}(\mathrm{OAc})_{2}$ but otherwise standard conditions (Entry 3$)$. No conversion $(<5 \%)$ was detected when $1 \mathrm{a}$ was mixed with only $\mathrm{Cu}(\mathrm{OAC})_{2}$ at $60^{\circ} \mathrm{C}$ (Entry 4). No change in ${ }^{11} \mathrm{~B} N M R$ spectrum was observed when $1 \mathrm{a}$ was reacted with 3.0 equivalents of $\mathrm{Cs}_{2} \mathrm{CO}_{3}$ at $60^{\circ} \mathrm{C}$ (Entry 5). Since CsOAc is potentially generated in situ (from the metathesis reaction between $\mathrm{Cu}(\mathrm{OAc})_{2}$ and $\mathrm{Cs}_{2} \mathrm{CO}_{3}$ ), we conducted two control reactions of $1 \mathrm{a}$ with only CsOAc (Entry 6) and with CsOAc and $\mathrm{Cu}(\mathrm{OAc})_{2}$ (Entry 7) as additives. No reaction was observed in either experiment. Based on these results, both $\mathrm{Cu}(\mathrm{OAC})_{2}$ and $\mathrm{Cs}_{2} \mathrm{CO}_{3}$ are needed for the generation of the species with the ${ }^{11} \mathrm{~B} N M R$ signal at $0.47 \mathrm{ppm}$. The ${ }^{11} \mathrm{~B}$ NMR resonance in the area between 9 and $-7 \mathrm{ppm}$ is typical of tetracoordinated boron compounds bearing -OR groups. ${ }^{12} \mathrm{~A}$ tetracoordinated acylboron intermediate with the ${ }^{11} \mathrm{~B}$ NMR chemical shift of $2.32 \mathrm{ppm}$ was recently observed by Mankad and co-workers in the copper-catalyzed carbonylative borylation of alkyl halides, as tricoordinated pinacol-acylboron coordinated with one equivalent of LiOtBu. ${ }^{4 g}$ Bode and co-workers originally proposed that hydrolysis of MIDA acylboronate leads to the highly reactive boron-ligated intermediate, $^{8 a}$ which either undergoes ligation with $O$-Me hydroxylamines or rapid protodeboronation in the presence of water. ${ }^{9}$ In our study, the observed intermediate with the ${ }^{11} \mathrm{~B}$ NMR signal of $0.47 \mathrm{ppm}$ likely corresponds to the tetracoordinated boron species $\mathrm{I}$, where $\mathrm{X}$ is either acetate or carbonate anions.

To assess whether or not $\mathbf{I}$ is the reactive intermediate in the reaction, a sub-stoichiometric amount of 1a was subjected to the standard conditions (Scheme 4). The signal at $0.47 \mathrm{ppm}$ appeared after 1 hour and its intensity continued to increase, while the peak corresponding to $1 \mathrm{a}$ 
decreased. Gratifyingly, once 1a was consumed ( 11 hours), the resonance at $0.47 \mathrm{ppm}$ began to disappear. After 16 hours, complete consumption of I was observed confirming the intermediacy of the species.
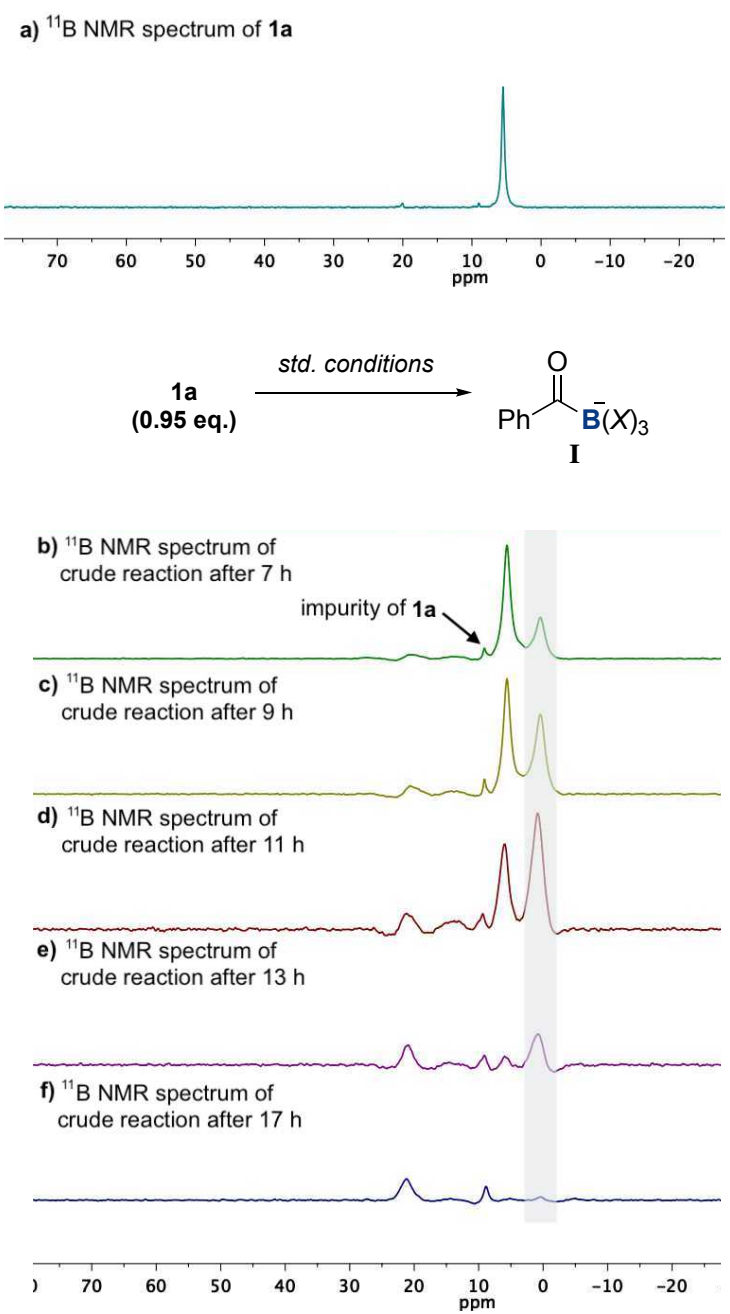

Scheme 4. Mechanistic analysis by ${ }^{11} B$ NMR spectroscopy. a) ${ }^{11} B$ NMR spectrum of $1 \mathrm{a} ;{ }^{11} B$ NMR spectra of the crosscoupling reaction of MIDA acylboronate 1a (0.95 eq.), aryl bromide (1.0 eq.), XPhos Pd G2 (10 mol \%), Cu(OAc) 2 (1.5 eq.), $\mathrm{Cs}_{2} \mathrm{CO}_{3}$ (3.0 eq.) in DMF (0.1 M), $60^{\circ} \mathrm{C}$, monitored over b) 7 hours; c) 9 hours; d) 11 hours; e) 13 hours; f) 17 hours.

We then turned our attention to detecting the hypothesized intermediacy of an acyl palladium complex. The progress of a stoichiometric reaction of $\mathbf{1 a}, \mathbf{2} \mathbf{a}$, and Pd pre-catalyst was monitored by ${ }^{31}$ P NMR spectrometry over 16 hours under standard conditions (Scheme 5). After 15 minutes, the signals at $41.9 \mathrm{ppm}$, which corresponded to XPhos oxide, and $27.4 \mathrm{ppm}$ appeared. The latter was assigned to the oxidative addition palladium complex III, which chemical shift was consistent with previous literature reports. ${ }^{13}$ After 1 hour, a new signal at $25.9 \mathrm{ppm}$ appeared and its intensity continued to rise while the resonance of III slowly disappeared. This new signal, upfield of $1.5 \mathrm{ppm}$ from that of complex III, was assigned to the acyl palladium species IV. A similar upfield shift for analogous carbonylated complexes was observed by the Moser ${ }^{14}$ and Yamamoto ${ }^{15}$ 
groups in Pd-catalyzed carbonylation reactions with carbon monoxide. Moreover, IV was detected by HRMS (ESI+) under stoichiometric conditions with the expected isotopic distribution.

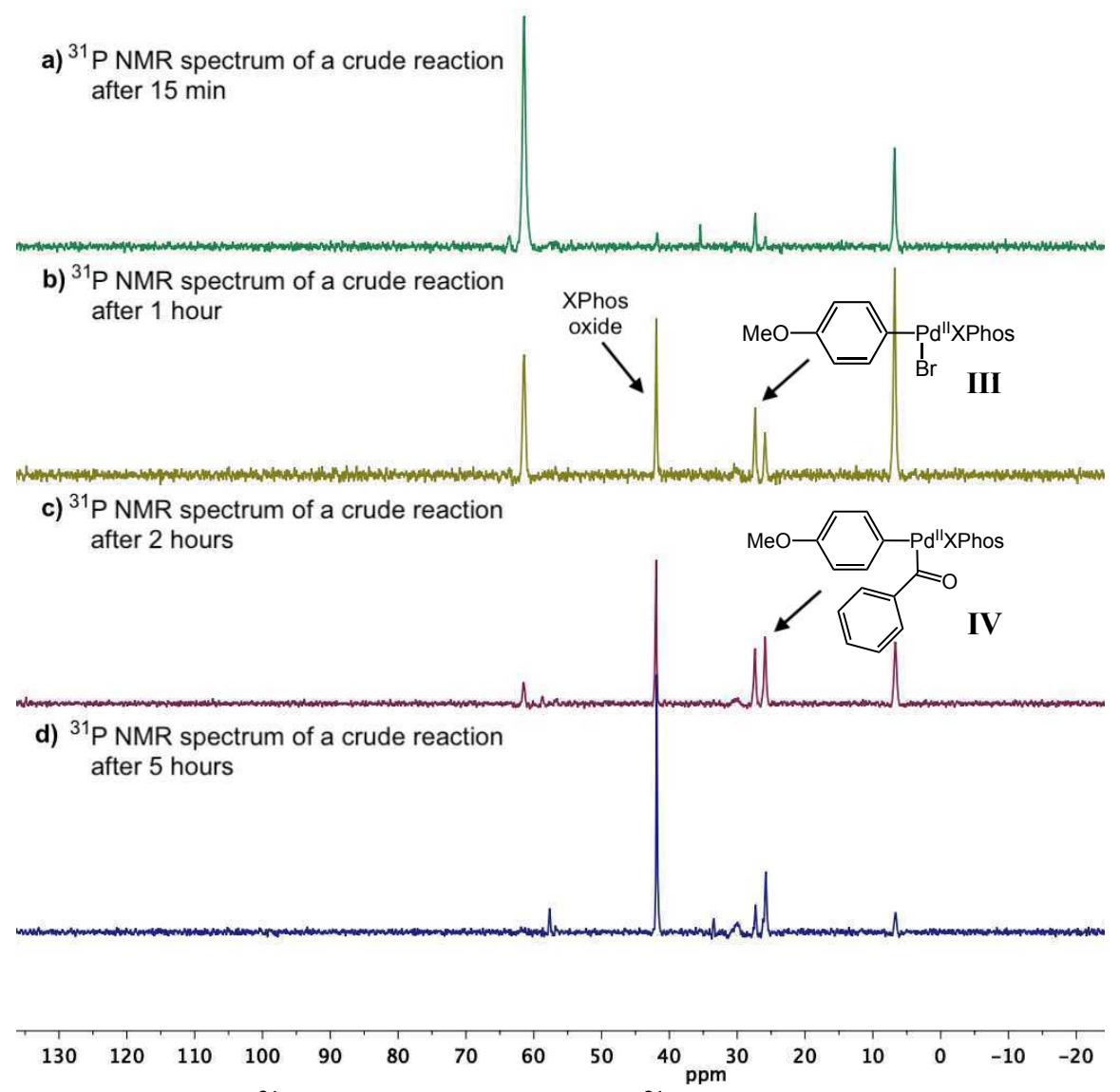

Scheme 5. Mechanistic analysis by ${ }^{31} \mathrm{P}$ NMR spectroscopy. a)-d) ${ }^{31} \mathrm{P}$ NMR spectrum of the stoichiometric reaction of MIDA acylboronate $1 \mathrm{a}$ (1.5 eq.), 4-bromoanisole (1.0 eq.), XPhos Pd G2 (1.0 eq.), $\mathrm{Cu}(\mathrm{OAc})_{2}$ (1.5 eq.), $\mathrm{Cs}_{2} \mathrm{CO}_{3}(3.0$ eq.) in DMF (0.1 M), $60^{\circ} \mathrm{C}$; a) $15 \mathrm{~min}$; b) 1 hour; c) 2 hours; d) 5 hours.

Based on the experimental results and previously reported literature, a plausible reaction mechanism shown in Scheme 6 was proposed. According to this scheme, acylboronate 1 reacts with $\mathrm{Cu}(\mathrm{OAC})_{2}$ and $\mathrm{Cs}_{2} \mathrm{CO}_{3}$ to generate intermediate $\mathrm{I}$, which was observed by ${ }^{11} \mathrm{~B} \mathrm{NMR}$ spectrometry, and 2 equivalents of $\mathrm{CsOAc}$. Further transmetalation affords acyl copper species II. The $\mathrm{Pd}(0)$ active catalyst is generated from the base-mediated reductive elimination of the $\mathrm{Pd}(\mathrm{II})$ pre-catalyst. Oxidative addition with aryl bromide affords intermediate III. Subsequent transmetalation with II or directly with I gives acyl palladium complex IV. Further reductive elimination provides the desired ketone 3 and regenerates the active catalyst. 


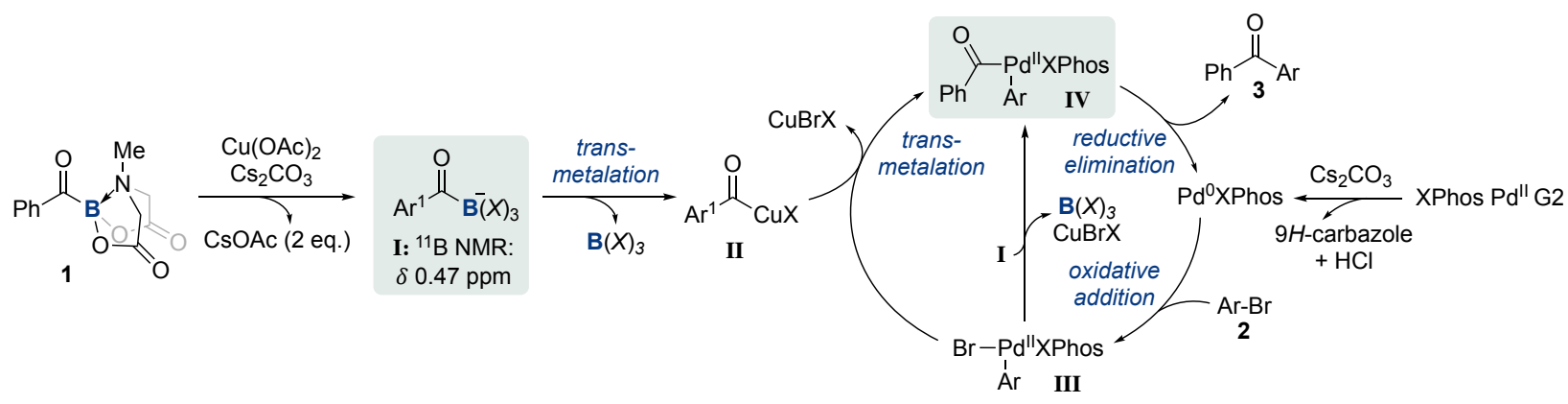

Scheme 6. Proposed mechanism of the Suzuki-Miyaura reaction reaction of MIDA acylboronates.

In summary, we have developed a new Pd-catalyzed cross-coupling reaction between aryl (pseudo)halides and MIDA acylboronates that serve as acyl anion equivalents. The mild reaction conditions were found to be compatible with various aliphatic and aromatic acylboronates. ${ }^{11} \mathrm{~B}$ and ${ }^{31} \mathrm{P}$ NMR mechanistic studies, as well as mass spectrometry, revealed that the tetracoordinated boron and acyl palladium(II) species are possible reaction intermediates. Further exploration of boron-based acyl anion equivalents in chemical synthesis as well as studies aimed at defining broader utility for the $\operatorname{ArC}(\mathrm{O}) \mathrm{B}(\mathrm{OH})_{2}$ class of molecules are underway in our laboratory.

\section{References:}

(1) Seebach, D. Angew. Chem., Int. Ed. Engl. 1979, 18, 239-258.

(2) Bugaut, X.; Glorius, F. Chem. Soc. Rev. 2012, 41, 3511-3522.

(3) For reviews on synthesis and applications of acylboronates, see: a) Scharnagl, K.; Bose, S. K.; Marder, T. B. Org. Biomol. Chem. 2017, 15, 1738-1752; b) Wu, D.; Taguchi, J.; Tanriver, M.; Bode, J. W. Angew. Chem., Int. Ed. 2020, 59, 16847-16858.

(4) For papers on synthesis of acylboronates, see: a) Molander, G. A.; Raushel, J.; Ellis, N. M. J. Org. Chem. 2010, 75, 4304-4306; b) Erős, G.; Kushida, Y.; Bode, J. W. Angew. Chem., Int. Ed. 2014, 53, 7604-7607; c) He, Z.; Trinchera, P.; Adachi, S.; St. Denis, J. D.; Yudin, A. K. Angew. Chem., Int. Ed. 2012, 51, 11092-11096; d) Taguchi, J.; Ikeda, T.; Takahashi, R.; Sasaki, I.; Ogasawara, Y.; Dairi, T.; Kato, N.; Yamamoto, Y.; Bode, J. W.; Ito, H. Angew. Chem., Int. Ed. 2017, 56, 13847-13851; e) Lepage, M. L.; Lai, S.; Peressin, N.; Hadjerci, R.; Patrick, B. O.; Perrin, D. M. Angew. Chem., Int. Ed. 2017, 56, 15257-15261; f) Lin, S.; Wang, L.; Aminoleslami, N.; Lao, Y.; Yagel, C.; Sharma, A. Chem. Sci. 2019, 10, 4684-4691; g) Cheng, L.-J.; Zhao, S.; Mankad, N. P. Angew. Chem., Int. Ed. 2021, 60, 2094-2098; h) Schuhmacher, A.; Ryan, S. J.; Bode, J. W. Angew. Chem., Int. Ed. 2021, 60, 3918-3922.

(5) Hillman, M. E. D. J. Am. Chem. Soc. 1962, 84, 4715-4720; b) Hillman, M. E. D. J. Am. Chem. Soc. 1963, 85, 982984.

(6) Gillis, E. P.; Burke, M. D. J. Am. Chem. Soc. 2008, 130, 14084-14085.

(7) Li, J.; Ballmer, S. G.; Gillis, E. P.; Fujii, S.; Schmidt, M. J.; Palazzolo, A. M. E.; Lehmann, J. W.; Morehouse, G. F.; Burke, M. D. Science 2015, 347, 1221-1226.

(8) For papers on applications of acylboronates, see: a) Noda, H.; Bode, J. W. Chem. Sci. 2014, 5, 4328-4332; b) Diaz, D. B.; Scully, C. C. G.; Liew, S. K.; Adachi, S.; Trinchera, P.; St. Denis, J. D.; Yudin, A. K. Angew. Chem., Int. Ed. 2016, 55, 12659-12663; c) Lee, C. F.; Holownia, A.; Bennett, J. M.; Elkins, J. M.; St. Denis, J. D.; Adachi, S.; Yudin, A. K. Angew. Chem., Int. Ed. 2017, 56, 6264-6267.; d) Lee, C. F.; Diaz, D. B.; Holownia, A.; Kaldas, S. J.; Liew, S. K.; Garrett, G. E.; Dudding, T.; Yudin, A. K. Nature Chem. 2018, 10, 1062-1070; e) Tan, D.-H.; Cai, Y.-H.; Zeng, Y.-F.; Lv, W.-X.; Yang, L.; Li, Q.; Wang, H. Angew. Chem., Int. Ed. 2019, 58, 13784-13788; f) Ivon, Y. M.; Mazurenko, I. V.; Kuchkovska, Y. O.; Voitenko, Z. V.; Grygorenko, O. O. Angew. Chem., Int. Ed. 2020, 59, 18016-18022; g) Deng, X.; Zhou, G.; Han, X.; Ullah, K.; Srinivasan, R. Org. Lett. 2021, [early view]. 
(9) a) Nave, S.; Sonawane, R. P.; Elford, T. G.; Aggarwal, V. K. J. Am. Chem. Soc. 2010, 132, 17096-17098; b) Watson, C. G.; Balanta, A.; Elford, T. G.; Essafi, S.; Harvey, J. N.; Aggarwal, V. K. J. Am. Chem. Soc. 2014, 136, 17370-17373.

(10) For cross-coupling reactions of acylsilanes, acylzirconocenes, and acylindium compounds, see: a) Schmink, J. R.; Krska, S. W. J. Am. Chem. Soc. 2011, 133, 19574-19577; b) Ramgren, S. D.; Garg, N. K. Org. Lett. 2014, 16, 824-827; c) Obora, Y.; Ogawa, Y.; Imai, Y.; Kawamura, T.; Tsuji, Y. J. Am. Chem. Soc. 2001, 123, 10489-10493; d) Obora, Y.; Nakanishi, M.; Tokunaga, M.; Tsuji, Y. J. Org. Chem. 2002, 67, 5835-5837; e) Hanzawa, Y.; Tabuchi, N.; Taguchi, T. Tetrahedron Lett. 1998, 39, 6249-6252; f) Lee, D.; Ryu, T.; Park, Y.; Lee, P. H. Org. Lett. 2014, 16, 1144-1147.

(11) a) Lennox, A. J. J.; Lloyd-Jones, G. C. Angew. Chem., Int. Ed. 2013, 52, 7362-7370; b) Thomas, A. A.; Wang, H.; Zahrt A. F.; Denmark, S. E. J. Am. Chem. Soc. 2017, 139, 3805-3821.

(12) Wrackmeyer, B. "Organoboron chemistry." In Modern Magnetic Resonance, Springer, Dordrecht 2008, 455-457.

(13) a) Lee, H. G.; Lautrette, G.; Pentelute, B. L.; Buchwald, S. L. Angew. Chem., Int. Ed. 2017, 56, 3177-3181. b) Mateos-Gil, J.; Mondal, A.; Castiñeira, M. R.; Feringa, B. L. Angew. Chem., Int. Ed. 2020, 59, 7823-7829.

(14) Moser, W. R.; Wang, A. W.; Kildahl, N. K. J. Am. Chem. Soc. 1988, 110, 2816-2820.

(15) Ozawa, F.; Sugimoto, T.; Yuasa, Y.; Santra,M.; Yamamoto, T.; Yamamoto, A. Organometallics 1984, 3, 683-692. 


\section{Acylboronates in Polarity-Reversed Generation of Acyl Palladium(II) Intermediates}

Alina Trofimova, ${ }^{\dagger}$ Aleksandra Holownia, ${ }^{\dagger}$ Chieh-Hung Tien, Martynas J. Širvinskas, and Andrei K. Yudin*

Davenport Research Laboratories, Department of Chemistry, University of Toronto, 80 St. George Street, Toronto, Ontario, Canada M5S 3 H6

\section{Supplementary Information}

\section{Table of Contents}

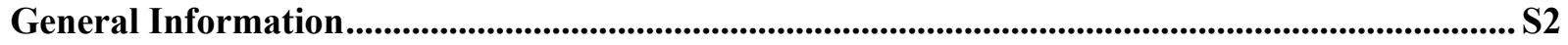

Experimental procedure and characterization of compounds ..............................................................S3

Optimization of SMCC reaction conditions....................................................................................... S3

General procedure of the SMCC reaction with MIDA acylboronates..................................................... S4

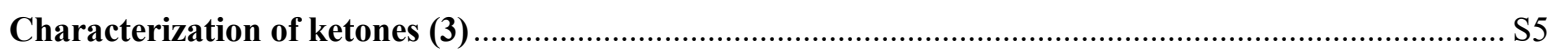

General procedure for control reactions monitored by ${ }^{11} \mathrm{~B}$ NMR of the SMCC reaction ..................... S10

${ }^{11} B$ NMR spectra of the control reactions of the SMCC reaction .......................................................... S11

General procedure for the stoichiometric reaction monitored by ${ }^{31} \mathrm{P}$ NMR of the SMCC reaction ...... S15

${ }^{31} \mathrm{P}$ NMR and mass spectrometry spectra of the stoichiometric reactions of the SMCC reaction ......... S16

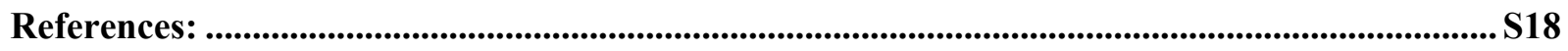




\section{General Information}

\section{Solvents}

All solvents and reagents were purchased from commercial sources and dried over $4 \AA$ MS prior to use unless otherwise stated. Dioxane and toluene were distilled from sodium benzophenone ketyl prior to use. Acetonitrile $(\mathrm{MeCN})$ was distilled from calcium hydride prior to use. Dimethylformamide (DMF) was purchased from MilliporeSigma in a Sure/Seal ${ }^{\mathrm{TM}}$ bottle and used as received. Acyl MIDA boronates (1a-1g) were synthesized according to literature procedures. ${ }^{[1}$, 2]

\section{Chromatography}

Flash column chromatography was carried out using Silicycle 230-400 mesh silica gel. Thin-layer chromatography was performed on Merck Aluminum-backed TLC Silica gel 60 F254 and visualized using a UV lamp (254 nm) and curcumin stain.

\section{Nuclear Magnetic Resonance Spectroscopy}

${ }^{1} \mathrm{H},{ }^{11} \mathrm{~B},{ }^{13} \mathrm{C},{ }^{31} \mathrm{P}$, and ${ }^{19} \mathrm{~F}$ NMR and $2 \mathrm{D}$ NMR experiments were performed on Varian Mercury 300 $\mathrm{MHz}, 400 \mathrm{MHz}, 500 \mathrm{MHz}, 600 \mathrm{MHz}$ or Bruker $400 \mathrm{MHz}$ spectrometers. ${ }^{11} \mathrm{~B}$ NMR chemical shifts $(\delta)$ are reported in parts per million $(\mathrm{ppm})$ referenced to an external standard of $\mathrm{BF}_{3} \cdot \mathrm{Et}_{2} \mathrm{O}(\delta$ $=0 \mathrm{ppm}) .{ }^{1} \mathrm{H}$ NMR chemical shifts $(\delta)$ are reported in parts per million (ppm) referenced to residual protonated solvent peak $\left(\mathrm{CD}_{3} \mathrm{CN} \delta=1.94 \mathrm{ppm}, \mathrm{CDCl}_{3} \delta=7.26 \mathrm{ppm}\right)$. Spectral data is reported as follows: chemical shift, multiplicity ( $\mathrm{s}=$ singlet, $\mathrm{d}=$ doublet, $\mathrm{t}=$ triplet, $\mathrm{q}=$ quartet, $\mathrm{dd}=$ doublet of doublets, $\mathrm{dt}=$ doublet of triplets, $\mathrm{ddt}=$ doublet of doublet of triplets, $\mathrm{dtd}=$ doublet of triplet of doublets, $\mathrm{m}=$ multiplet, $\mathrm{br}=$ broad $)$, coupling constant $(\mathrm{J})$ in $\operatorname{Hertz}(\mathrm{Hz})$, and integration. ${ }^{13} \mathrm{C} \mathrm{NMR}$ spectra chemical shifts $(\delta)$ are reported in parts per million $(\mathrm{ppm})$ and were referenced to carbon resonances in the corresponding NMR solvent $\left(\mathrm{CD}_{3} \mathrm{CN} \delta=118.2,1.3\right.$ (center line), $\mathrm{CDCl}_{3} \delta=$ 77.1 (center line)). Carbon atoms exhibiting significant line broadening brought about by boron

substituents were not reported due to quadrupolar relaxation. ${ }^{19} \mathrm{~F}$ NMR chemical shifts $(\delta)$ are reported in parts per million (ppm) and referenced to an external standard of $\mathrm{CFCl}_{3}(\delta=0.0)$. 


\section{Mass Spectroscopy}

High resolution mass spectra were obtained on a VG 70-250S (double focusing) mass spectrometer at $70 \mathrm{eV}$ or on an $\mathrm{ABI} / \mathrm{Sciex}$ Qstar mass spectrometer with ESI or DART source, MS/MS and accurate mass capabilities.

\section{RP-HPLC/MS}

Low-resolution mass spectra (ESI) were collected on an Agilent Technologies 1200 series HPLC paired to a 6130 Mass Spectrometer. Compounds were resolved on Phenomenex's Kinetex 2.6u C18 50x4.6mm column at room temperature with a flow of $1 \mathrm{~mL} / \mathrm{min}$. The gradient consisted of eluents A $(0.1 \%$ formic acid in double distilled water) and B (0.1\% formic acid in HPLC-grade acetonitrile).

\section{Experimental procedure and characterization of compounds}

\section{Optimization of SMCC reaction conditions}

To a flame-dried vial equipped with a stir bar was added acyl MIDA boronate (1a) $(0.075 \mathrm{mmol}$, 1.5 eq.), Pd pre-catalyst ( $0.005 \mathrm{mmol}, 10 \mathrm{~mol} \%)$, additive $(0.075 \mathrm{mmol}, 1.5$ eq. $)$, and a base $(0.25$ mmol, 5.0 eq.). The vial was evacuated and backfilled with nitrogen. This was repeated three times. Aryl halide (0.05 mmol, 1.0 eq.) and solvent $(0.1 \mathrm{M})$ were subsequently added, and the reaction was stirred for $16 \mathrm{~h}$ in a heating block set to the indicated temperature. Upon completion, as indicated by TLC, the reaction was filtered. The assay yield of $\mathbf{3 a}$ was determined by ${ }^{1} \mathrm{H}$ NMR using 1,3,5-trimethoxybenzene as an internal standard. 


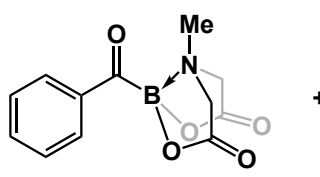

$1 \mathrm{a}$

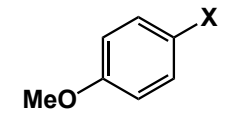

$2 a$
$X=B r$

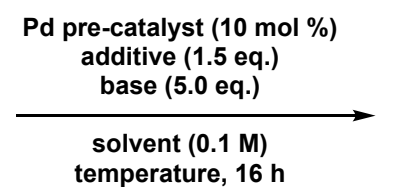

temperature, $16 \mathrm{~h}$

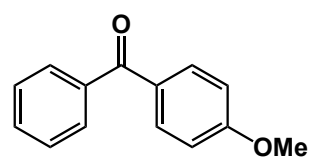

$3 a$

\begin{tabular}{|c|c|c|c|c|c|c|}
\hline entry & Pd pre-catalyst & base & additive & solvent & temp & yield $(\%)$ \\
\hline $1^{[\mathrm{a}]^{0}}$ & XPhos Pd G2 & $\mathrm{K}_{2} \mathrm{CO}_{3}$ & $\mathrm{Cu}(\mathrm{OAc})_{2}$ & 4:1 DMF:t-amylOH & 80 & 44 \\
\hline $2^{[a]}$ & XPhos Pd G2 & $\mathrm{K}_{2} \mathrm{CO}_{3}$ & $\mathrm{Cu}(\mathrm{OAc})_{2}$ & 4:1 DMF:IPA & 80 & 33 \\
\hline $3^{[\mathrm{a}]}$ & XPhos Pd G2 & $\mathrm{K}_{2} \mathrm{CO}_{3}$ & $\mathrm{Cu}(\mathrm{OAc})_{2}$ & DMF & 80 & 49 \\
\hline $4^{[b]}$ & XPhos Pd G2 & $\mathrm{K}_{2} \mathrm{CO}_{3}$ & $\mathrm{Cu}(\mathrm{OAc})_{2}$ & DMF & 80 & 47 \\
\hline $5^{[b]}$ & XPhos Pd G2 & $\mathrm{K}_{2} \mathrm{CO}_{3}$ & $\mathrm{Cu}(\mathrm{OAc})_{2}$ & $\mathrm{MeCN}$ & 80 & 13 \\
\hline $6^{[b]}$ & XPhos Pd G2 & $\mathrm{K}_{2} \mathrm{CO}_{3}$ & $\mathrm{Cu}(\mathrm{OAc})_{2}$ & toluene & 80 & 19 \\
\hline $7^{[\mathrm{b}]}$ & XPhos Pd G2 & $\mathrm{K}_{2} \mathrm{CO}_{3}$ & $\mathrm{Cu}(\mathrm{OAc})_{2}$ & dioxane & 80 & 12 \\
\hline $8^{[b]}$ & XPhos Pd G2 & $\mathrm{K}_{2} \mathrm{CO}_{3}$ & $\mathrm{CuCl}$ & DMF & 80 & 10 \\
\hline $9^{[b]}$ & XPhos Pd G2 & $\mathrm{K}_{2} \mathrm{CO}_{3}$ & $\mathrm{CuI}$ & DMF & 80 & 6 \\
\hline $10^{[b]}$ & XPhos Pd G2 & $\mathrm{K}_{2} \mathrm{CO}_{3}$ & $\mathrm{Cu}(\mathrm{OAc})_{2}{ }^{[\mathrm{c}]}$ & DMF & 80 & 17 \\
\hline $11^{[\mathrm{b}]}$ & XPhos Pd G3 & $\mathrm{K}_{2} \mathrm{CO}_{3}$ & $\mathrm{Cu}(\mathrm{OAc})_{2}$ & DMF & 80 & 37 \\
\hline $12^{[b]}$ & CPhos Pd G2 & $\mathrm{K}_{2} \mathrm{CO}_{3}$ & $\mathrm{Cu}(\mathrm{OAc})_{2}$ & DMF & 80 & 36 \\
\hline $13^{[b]}$ & SPhos Pd G2 & $\mathrm{K}_{2} \mathrm{CO}_{3}$ & $\mathrm{Cu}(\mathrm{OAc})_{2}$ & DMF & 80 & 30 \\
\hline $14^{[b]}$ & RuPhos Pd G2 & $\mathrm{K}_{2} \mathrm{CO}_{3}$ & $\mathrm{Cu}(\mathrm{OAc})_{2}$ & DMF & 80 & 26 \\
\hline $15^{[b]}$ & XPhos Pd G2 & $\mathrm{K}_{2} \mathrm{CO}_{3}$ & $\mathrm{Cu}(\mathrm{OAc})_{2}$ & DMF & 100 & 36 \\
\hline $16^{[b]}$ & XPhos Pd G2 & $\mathrm{K}_{3} \mathrm{PO}_{4}$ & $\mathrm{Cu}(\mathrm{OAc})_{2}$ & DMF & 80 & 24 \\
\hline $17^{[\mathbf{b}]}$ & XPhos Pd G2 & $\mathrm{Cs}_{2} \mathrm{CO}_{3}$ & $\mathrm{Cu}(\mathrm{OAc})_{2}$ & DMF & 80 & 61 \\
\hline $18^{[b]}$ & XPhos Pd G2 & $\mathrm{Cs}_{2} \mathrm{CO}_{3}$ & $\mathrm{Cu}(\mathrm{OAc})_{2}$ & DMF & 60 & $73(66 \%)$ \\
\hline
\end{tabular}

Table S1. The SMCC reaction optimization. 1a (1.5 eq.), Pd pre-catalyst (10 mol \%), additive (1.5 eq.) and base (5.0 eq.) were combined in a flame-dried 0.5-dram vial under nitrogen atmosphere. Solvent $(0.1 \mathrm{M})$ was added followed by $p$-bromo- or iodoanisole ( $0.05 \mathrm{mmol}, 1.0$ eq.). The reaction was capped and stirred for 16 hours at the indicated temperature. Production of 3a was referenced to 1,3,5-trimethoxybenzene and the NMR yield was calculated accordingly. ${ }^{[a]}$ Reactions were carried out with $p$-iodoanisole. ${ }^{[b]}$ Reactions were carried out with $p$-bromoanisole. ${ }^{[c]}$ 0.75 eq. was used.

\section{General procedure of the SMCC reaction with MIDA acylboronates}

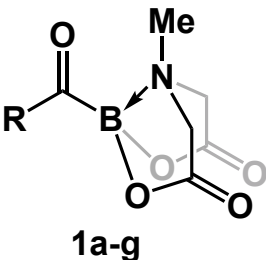

(1.5 eq.)

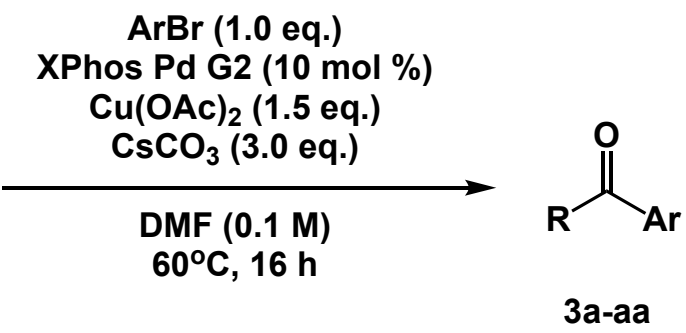

To a flame-dried vial equipped with a stir bar was added acyl MIDA boronate (1a-g) (0.15 mmol, 1.5 eq.), XPhos Pd G2 (0.01 mmol, $10 \mathrm{~mol} \%), \mathrm{Cs}_{2} \mathrm{CO}_{3}\left(0.3 \mathrm{mmol}, 3.0\right.$ eq.) and $\mathrm{Cu}(\mathrm{OAc})_{2}(0.15$ mmol, 1.5 eq.). The vial was evacuated and backfilled with nitrogen. This was repeated three times. $\operatorname{DMF}(0.1 \mathrm{M})$ and aryl bromide $(0.1 \mathrm{mmol}, 1.0$ eq. $)$ were subsequently added, and the reaction was 
stirred for $16 \mathrm{~h}$ in a heating block set to a temperature of $60^{\circ} \mathrm{C}$. Upon completion, as indicated by TLC, the reaction was filtered and loaded onto Celite. Purification via column chromatography provided the corresponding ketone products (3a-3aa).

\section{Characterization of ketones (3)}

\section{(4-Methoxyphenyl)(phenyl)methanone (3a) ${ }^{[3]}$}<smiles>COc1ccc(C(=O)c2ccccc2)cc1</smiles>

Yellow solid; $0.1 \mathrm{mmol}$ scale: $66 \%$ yield, $0.066 \mathrm{mmol}, 14.0 \mathrm{mg}$; $1 \mathrm{mmol}$ scale: $64 \%$ yield, $0.643 \mathrm{mmol}, 136.5 \mathrm{mg} ;{ }^{1} \mathrm{H} \mathrm{NMR}\left(500 \mathrm{MHz}, \mathrm{CDCl}_{3}\right) \delta$ $7.89-7.80(\mathrm{~m}, 2 \mathrm{H}), 7.78-7.73(\mathrm{~m}, 2 \mathrm{H}), 7.60-7.54(\mathrm{~m}, 1 \mathrm{H}), 7.50-7.45$ $(\mathrm{m}, 2 \mathrm{H}), 7.00-6.94(\mathrm{~m}, 2 \mathrm{H}), 3.89(\mathrm{~s}, 3 \mathrm{H}) \mathrm{ppm} ;{ }^{13} \mathrm{C} \mathrm{NMR}(126 \mathrm{MHz}$, $\left.\mathrm{CDCl}_{3}\right) \delta 195.7,163.4,138.4,132.7,132.0,130.3,129.9,128.3,113.7,55.6 \mathrm{ppm}$.

\section{(3-Methoxyphenyl)(phenyl)methanone (3b) ${ }^{[3]}$}<smiles>COc1cccc(C(=O)c2ccccc2)c1</smiles>

Yellow oil; $61 \%$ yield, $0.061 \mathrm{mmol}, 12.9 \mathrm{mg} ;{ }^{1} \mathrm{HNMR}\left(500 \mathrm{MHz}, \mathrm{CDCl}_{3}\right)$ $\delta 7.84-7.78(\mathrm{~m}, 2 \mathrm{H}), 7.62-7.52(\mathrm{~m}, 1 \mathrm{H}), 7.52-7.42(\mathrm{~m}, 2 \mathrm{H}), 7.40-$ $7.31(\mathrm{~m}, 3 \mathrm{H}), 7.12(\mathrm{ddd}, J=8.0,2.6,1.4 \mathrm{~Hz}, 1 \mathrm{H}), 3.84(\mathrm{~s}, 3 \mathrm{H}) \mathrm{ppm} ;{ }^{13} \mathrm{C}$ NMR (126 MHz, $\left.\mathrm{CDCl}_{3}\right) \delta 196.5,159.6,138.9,137.7,132.5,130.1,129.3,128.3,122.9,118.9$, $114.4,55.5 \mathrm{ppm}$.

\section{(2-Methoxyphenyl)(phenyl)methanone (3c) ${ }^{[3]}$}

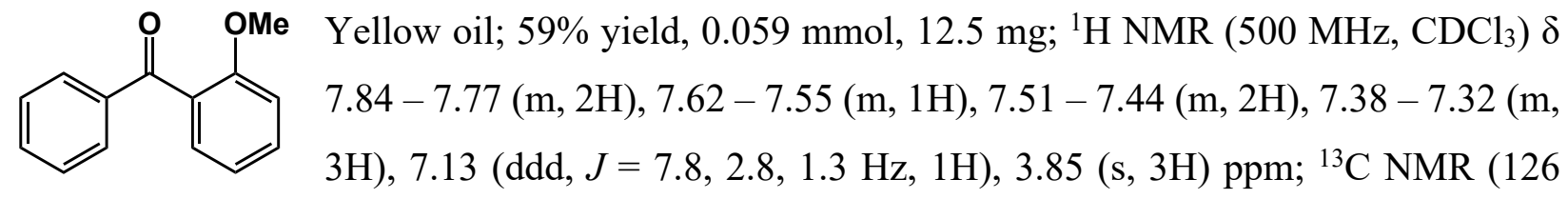
$\left.\mathrm{MHz}_{\mathrm{CDCl}}\right) \delta 196.6,159.7,139.0,137.7,132.5,130.1,129.3,128.3,122.9,118.9,114.4,55.5$ ppm.

\section{(4-(Dimethylamino)phenyl)(phenyl)methanone (3d) ${ }^{[4]}$}<smiles>CN(C)c1ccc(C(=O)c2ccccc2)cc1</smiles>

Green solid; 57\% yield, $0.057 \mathrm{mmol}, 12.8 \mathrm{mg} ;{ }^{1} \mathrm{H}$ NMR $(500 \mathrm{MHz}$, $\left.\mathrm{CDCl}_{3}\right) \delta 7.83-7.79(\mathrm{~m}, 2 \mathrm{H}), 7.76-7.69(\mathrm{~m}, 2 \mathrm{H}), 7.56-7.48(\mathrm{~m}, 1 \mathrm{H})$, $7.48-7.42(\mathrm{~m}, 2 \mathrm{H}), 6.72-6.63(\mathrm{~m}, 2 \mathrm{H}), 3.06(\mathrm{~d}, J=0.9 \mathrm{~Hz}, 6 \mathrm{H}) \mathrm{ppm}$; 
${ }^{13} \mathrm{C} \mathrm{NMR}\left(126 \mathrm{MHz}, \mathrm{CDCl}_{3}\right) \delta 195.2,153.4,139.4,132.8,131.2,129.5,128.1,124.8,110.6,40.1$ ppm.

\section{(3,4-Dimethoxyphenyl)(phenyl)methanone $(3 e)^{[3]}$}

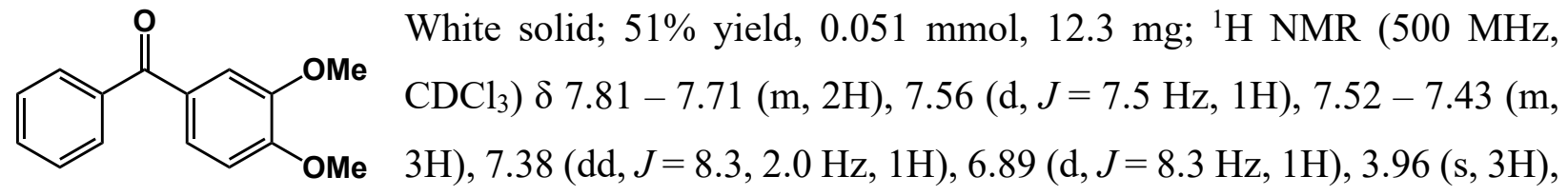
$3.94(\mathrm{~s}, 3 \mathrm{H}) \mathrm{ppm} ;{ }^{13} \mathrm{C} \mathrm{NMR}\left(126 \mathrm{MHz}, \mathrm{CDCl}_{3}\right) \delta 195.7,153.1,149.1,138.4,132.0,130.4,129.8$, $128.3,125.6,112.2,109.9,56.2,56.2 \mathrm{ppm}$.

\section{Phenyl(p-tolyl)methanone (3f $)^{[3]}$}

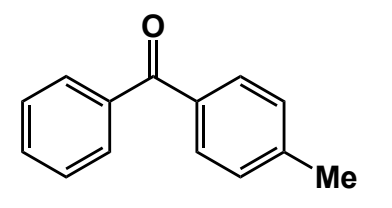

Yellow oil; 41\% yield, $0.041 \mathrm{mmol}, 8 \mathrm{mg} ;{ }^{1} \mathrm{H}$ NMR $\left(500 \mathrm{MHz}, \mathrm{CDCl}_{3}\right) \delta$ $7.81-7.76(\mathrm{~m}, 2 \mathrm{H}), 7.75-7.71(\mathrm{~m}, 2 \mathrm{H}), 7.60-7.55(\mathrm{~m}, 1 \mathrm{H}), 7.50-7.45$

$\left.\mathrm{MHz}, \mathrm{CDCl}_{3}\right) \delta 196.6,143.4,138.1,135.0,132.3,130.4,130.1,129.1,128.3,21.8,21.8 \mathrm{ppm}$.

\section{Phenyl(o-tolyl)methanone (3g) $)^{[3]}$}

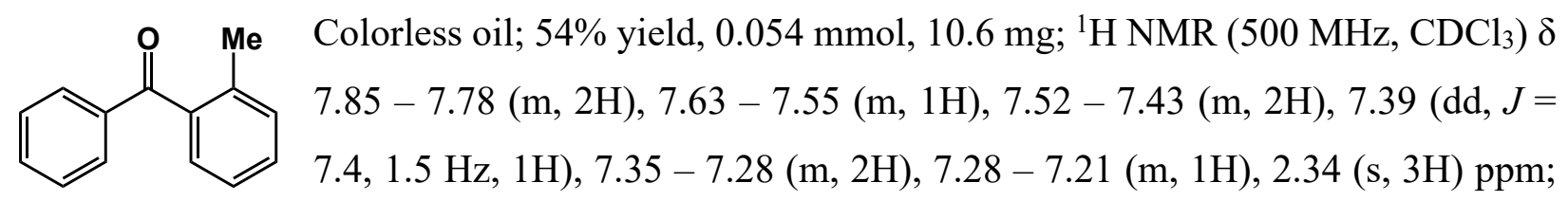

${ }^{13} \mathrm{C}$ NMR $\left(126 \mathrm{MHz}, \mathrm{CDCl}_{3}\right) \delta 198.8,138.7,137.9,136.9,133.3,131.1,130.4,130.3,128.6$, 128.6, 125.3, 20.1 ppm.

\section{(2,6-Dimethylphenyl)(phenyl)methanone (3h) ${ }^{[5]}$}<smiles>Cc1cc(C)cc(C(=O)c2ccccc2)c1</smiles>

Yellow solid; 68\% yield, $0.068 \mathrm{mmol}, 14.2 \mathrm{mg} ;{ }^{1} \mathrm{H}$ NMR $(500 \mathrm{MHz}$, $\left.\mathrm{CDCl}_{3}\right) \delta 7.82-7.76(\mathrm{~m}, 2 \mathrm{H}), 7.61-7.55(\mathrm{~m}, 1 \mathrm{H}), 7.50-7.45(\mathrm{~m}, 2 \mathrm{H})$, 7.41 (dt, $J=1.6,0.8 \mathrm{~Hz}, 2 \mathrm{H}), 7.22$ (tt, $J=1.7,0.8 \mathrm{~Hz}, 1 \mathrm{H}), 2.38(\mathrm{~s}, 6 \mathrm{H})$ ppm; $\left.{ }^{13} \mathrm{C} \mathrm{NMR} \mathrm{(126} \mathrm{MHz,} \mathrm{CDCl}_{3}\right) \delta 197.3,138.0,138.0,137.8,134.2$, $132.4,130.2,130.1,128.4,128.3,127.9,21.3 \mathrm{ppm}$. 


\section{Mesityl(phenyl)methanone (3i) ${ }^{[6]}$}

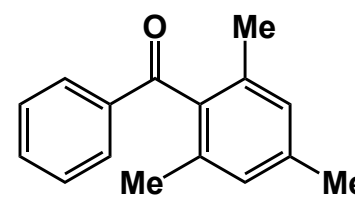

Yellow oil; $26 \%$ yield, $0.026 \mathrm{mmol}, 5.9 \mathrm{mg}$; ${ }^{1} \mathrm{H}$ NMR (500 MHz, $\mathrm{CDCl}_{3}$ ) $\delta 7.88-7.73(\mathrm{~m}, 2 \mathrm{H}), 7.64-7.51(\mathrm{~m}, 1 \mathrm{H}), 7.51-7.38(\mathrm{~m}, 2 \mathrm{H}), 6.90(\mathrm{t}, J$ $\delta$ 200.9, 138.6, 137.4, 137.0, 134.3, 133.7, 129.5, 128.9, 128.5, 21.2, 19.5 ppm.

\section{Benzophenone (3j) $)^{[3]}$}<smiles>O=C(c1ccccc1)c1ccccc1</smiles>

Off-white solid; 56\% yield, $0.056 \mathrm{mmol}, 10.1 \mathrm{mg} ;{ }^{1} \mathrm{H}$ NMR (500 $\left.\mathrm{MHz}, \mathrm{CDCl}_{3}\right)$ $\delta 7.84-7.78(\mathrm{~m}, 4 \mathrm{H}), 7.63-7.54(\mathrm{~m}, 2 \mathrm{H}), 7.52-7.45(\mathrm{~m}, 4 \mathrm{H}) \mathrm{ppm} ;{ }^{13} \mathrm{C} \mathrm{NMR}$ $\left(126 \mathrm{MHz}, \mathrm{CDCl}_{3}\right) \delta 196.9,137.7,132.5,130.2,128.4$ ppm.

\section{Naphthalen-2-yl(phenyl)methanone (3k) ${ }^{[3]}$}<smiles>O=C(c1ccccc1)c1ccc2ccccc2c1</smiles>

Yellow oil; 43\% yield, $0.043 \mathrm{mmol}, 10.0 \mathrm{mg} ;{ }^{1} \mathrm{H}$ NMR (500 MHz, $\mathrm{CDCl}_{3}$ ) $\delta 8.28-8.26(\mathrm{~m}, 1 \mathrm{H}), 7.97-7.85(\mathrm{~m}, 6 \mathrm{H}), 7.67-7.49(\mathrm{~m}, 5 \mathrm{H}) \mathrm{ppm} ;{ }^{13} \mathrm{C}$ $\mathrm{NMR}\left(126 \mathrm{MHz}, \mathrm{CDCl}_{3}\right) \delta 196.9,138.0,135.4,134.9,132.5,132.4,132.0$, $130.2,129.5,128.5,128.4,128.4,127.9,126.9,125.9$ ppm.

\section{(4-Chlorophenyl)(phenyl)methanone (3I) $)^{[3]}$}<smiles>O=C(c1ccccc1)c1ccc(Cl)cc1</smiles>

White solid; 38\% yield, $0.038 \mathrm{mmol}, 8.2 \mathrm{mg}$; ${ }^{1} \mathrm{H}$ NMR (500 MHz, $\mathrm{CDCl}_{3}$ ) $\delta 7.79-7.71(\mathrm{~m}, 4 \mathrm{H}), 7.62-7.57(\mathrm{~m}, 1 \mathrm{H}), 7.52-7.42(\mathrm{~m}, 4 \mathrm{H}) \mathrm{ppm} ;{ }^{13} \mathrm{C}$ NMR (126 MHz, $\left.\mathrm{CDCl}_{3}\right) \delta 195.6,139.0,137.3,136.0,132.7,131.6,130.0$, $128.7,128.5 \mathrm{ppm}$.

\section{Phenyl(4-(trifluoromethyl)phenyl)methanone (3m) ${ }^{[3]}$}

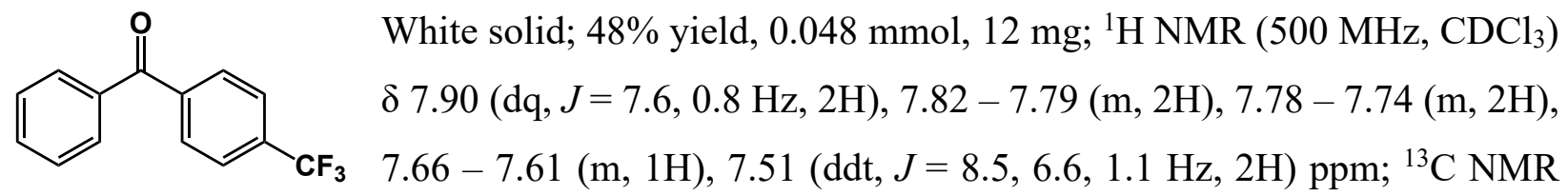
$\left(126 \mathrm{MHz}, \mathrm{CDCl}_{3}\right) \delta 195.7,140.9,136.9,133.9$ (q, $\left.J=32.7 \mathrm{~Hz}\right), 133.2,130.3,130.2,128.7,125.5$ $(\mathrm{q}, J=3.8 \mathrm{~Hz}), 123.8(\mathrm{~d}, J=272.6 \mathrm{~Hz}) \mathrm{ppm} ;{ }^{19} \mathrm{~F}$ NMR $\left(377 \mathrm{MHz}, \mathrm{CDCl}_{3}\right) \delta-63.01(\mathrm{~s}, 3 \mathrm{~F}) \mathrm{ppm}$. 


\section{6-Benzoyl-2,3-dihydro-1H-inden-1-one (3n)}<smiles>O=C(c1ccccc1)c1ccc2c(c1)C(=O)CC2</smiles>

Yellow oil; 31\% yield, $0.31 \mathrm{mmol}, 7.4 \mathrm{mg} ;{ }^{1} \mathrm{H}$ NMR (500 $\left.\mathrm{MHz}, \mathrm{CDCl}_{3}\right) \delta$ $8.15-8.02(\mathrm{~m}, 2 \mathrm{H}), 7.87-7.66(\mathrm{~m}, 2 \mathrm{H}), 7.68-7.55(\mathrm{~m}, 2 \mathrm{H}), 7.55-7.36$ $(\mathrm{m}, 2 \mathrm{H}), 3.33-3.16(\mathrm{~m}, 2 \mathrm{H}), 2.84-2.69(\mathrm{~m}, 2 \mathrm{H}) \mathrm{ppm} ;{ }^{13} \mathrm{C}$ NMR $(126$ $\left.\mathrm{MHz}, \mathrm{CDCl}_{3}\right) \delta 206.2,195.8,159.2,137.2,137.17,137.0,135.8,132.9,130.0,128.6,127.2,125.8$, 36.6, $26.2 \mathrm{ppm}$. HRMS (DART): $\mathrm{m} / \mathrm{z}$ calcd. for $\mathrm{C}_{16} \mathrm{H}_{13} \mathrm{O}_{2}\left([\mathrm{M}+\mathrm{H}]^{+}\right), 237.09101$; found, 237.09149 .

\section{Benzo $[b]$ thiophen-5-yl(phenyl)methanone (3o)}<smiles>O=C(c1ccccc1)c1ccc2sccc2c1</smiles>

Off-white solid; 65\% yield, $0.065 \mathrm{mmol}, 15.4 \mathrm{mg} ;{ }^{1} \mathrm{H}$ NMR (500 MHz, $\left.\mathrm{CDCl}_{3}\right) \delta 8.25(\mathrm{dd}, J=1.7,0.7 \mathrm{~Hz}, 1 \mathrm{H}), 7.97(\mathrm{dt}, J=8.3,0.8 \mathrm{~Hz}, 1 \mathrm{H}), 7.84$ $(\mathrm{dt}, J=8.3,1.8 \mathrm{~Hz}, 3 \mathrm{H}), 7.66-7.57(\mathrm{~m}, 1 \mathrm{H}), 7.57-7.47(\mathrm{~m}, 3 \mathrm{H}), 7.41$ $(\mathrm{dd}, J=5.5,0.8 \mathrm{~Hz}, 1 \mathrm{H}) \mathrm{ppm} ;{ }^{13} \mathrm{C} \mathrm{NMR}\left(126 \mathrm{MHz}, \mathrm{CDCl}_{3}\right) \delta 196.8,143.9,139.2,138.1,134.0$, 132.4, 130.1, 130.1, 128.4, 128.0, 126.4, 125.4, 124.6, 122.5 ppm. HRMS (DART): m/z calcd. for $\mathrm{C}_{15} \mathrm{H}_{11} \mathrm{OS}\left([\mathrm{M}+\mathrm{H}]^{+}\right), 239.05251$; found, 239.05307 .

(6-Methoxypyridin-3-yl)(phenyl)methanone (3p) $)^{[7]}$

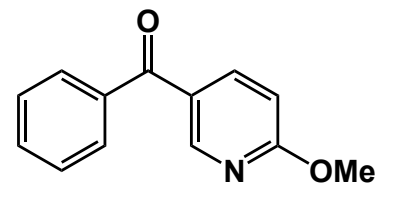

Colorless oil; 30\% yield, $0.030 \mathrm{mmol}, 6.5 \mathrm{mg} ;{ }^{1} \mathrm{H}$ NMR (500 MHz, $\left.\mathrm{CDCl}_{3}\right) \delta 8.62(\mathrm{dd}, J=2.5,0.7 \mathrm{~Hz}, 1 \mathrm{H}), 8.11(\mathrm{dd}, J=8.7,2.4 \mathrm{~Hz}, 1 \mathrm{H})$, 2H), $6.85(\mathrm{dd}, J=8.7,0.7 \mathrm{~Hz}, 1 \mathrm{H}), 4.03(\mathrm{~s}, 3 \mathrm{H}) \mathrm{ppm} ;{ }^{13} \mathrm{C} \mathrm{NMR}\left(126 \mathrm{MHz}, \mathrm{CDCl}_{3}\right) \delta$ 194.3, 166.6, $150.9,140.2,137.7,132.6,129.9,128.6,127.1,111.2,54.2 \mathrm{ppm}$.

\section{(4-Fluorophenyl)(4-methoxyphenyl)methanone $(3 \mathrm{~s})^{[5]}$}

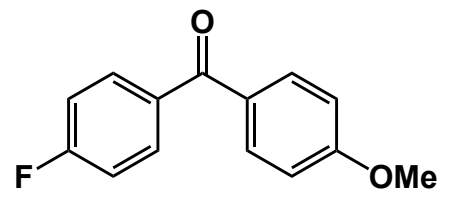

White solid; 82\% yield, $0.82 \mathrm{mmol}, 18.9 \mathrm{mg} ;{ }^{1} \mathrm{H}$ NMR $(400 \mathrm{MHz}$, $\left.\mathrm{CDCl}_{3}\right) \delta 7.79(\mathrm{dt}, J=8.7,2.6 \mathrm{~Hz}, 4 \mathrm{H}), 7.15(\mathrm{t}, J=8.6 \mathrm{~Hz}, 2 \mathrm{H}), 6.97$ $(\mathrm{d}, J=8.9 \mathrm{~Hz}, 2 \mathrm{H}), 3.88(\mathrm{~s}, 3 \mathrm{H}) \mathrm{ppm} ;{ }^{13} \mathrm{C} \mathrm{NMR}\left(126 \mathrm{MHz}, \mathrm{CDCl}_{3}\right) \delta$ $194.2,166.2,164.2,163.4,134.6(\mathrm{~d}, J=3.2 \mathrm{~Hz}), 132.5,132.4(\mathrm{~d}, J=$ $9.0 \mathrm{~Hz}), 130.1,115.4(\mathrm{~d}, J=21.8 \mathrm{~Hz}), 113.8,55.6 \mathrm{ppm} ;{ }^{19} \mathrm{~F}$ NMR $\left(377 \mathrm{MHz}, \mathrm{CDCl}_{3}\right) \delta-106.91$ $(\mathrm{s}, 1 \mathrm{~F}) \mathrm{ppm}$. 


\section{(4-(Dimethylamino)phenyl)(4-fluorophenyl)methanone $(3 t)^{[8]}$}

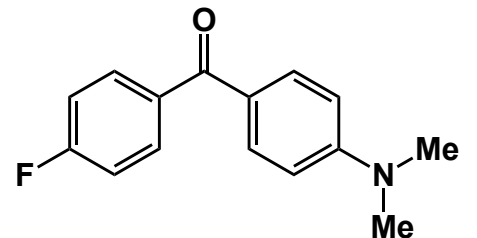

Yellow solid; 60\% yield, $0.060 \mathrm{mmol}, 14.7 \mathrm{mg}$; ${ }^{1} \mathrm{H}$ NMR $(400 \mathrm{MHz}$, $\left.\mathrm{CDCl}_{3}\right) \delta 7.85-7.68(\mathrm{~m}, 4 \mathrm{H}), 7.13(\mathrm{t}, J=8.7 \mathrm{~Hz}, 2 \mathrm{H}), 6.69(\mathrm{~d}, J=$ $9.0 \mathrm{~Hz}, 2 \mathrm{H}), 3.07$ (s, 6H) ppm; ${ }^{13} \mathrm{C} \mathrm{NMR}\left(126 \mathrm{MHz}, \mathrm{CDCl}_{3}\right) \delta 193.8$, $165.7,163.7,153.3,135.5(\mathrm{~d}, J=3.1 \mathrm{~Hz}), 132.7,132.0(\mathrm{~d}, J=8.7$ $\mathrm{Hz}), 115.2(\mathrm{~d}, J=21.8 \mathrm{~Hz}), 110.8,40.2 \mathrm{ppm} ;{ }^{19} \mathrm{~F}$ NMR $\left(377 \mathrm{MHz}, \mathrm{CDCl}_{3}\right) \delta-108.32$ (s, $\left.1 \mathrm{~F}\right) \mathrm{ppm}$.

Bis(4-methoxyphenyl)methanone (3u) $)^{[9]}$<smiles>COc1ccc(C(=O)c2ccc(OC)cc2)cc1</smiles>

White solid; 74\% yield, $0.074 \mathrm{mmol}, 17.8 \mathrm{mg} ;{ }^{1} \mathrm{H}$ NMR (400 $\left.\mathrm{MHz}, \mathrm{CDCl}_{3}\right) \delta 7.78(\mathrm{~d}, J=8.9 \mathrm{~Hz}, 4 \mathrm{H}), 6.95(\mathrm{~d}, J=8.8 \mathrm{~Hz}, 4 \mathrm{H})$, $3.87(\mathrm{~s}, 6 \mathrm{H}) \mathrm{ppm} ;{ }^{13} \mathrm{C} \mathrm{NMR}\left(126 \mathrm{MHz}, \mathrm{CDCl}_{3}\right) \delta 194.5,162.9$, $132.3,130.8,113.6,55.6 \mathrm{ppm}$.

(4-(Dimethylamino)phenyl)(4-methoxyphenyl)methanone (3v) ${ }^{[9]}$<smiles>COc1ccc(C(=O)c2ccc(N(C)C)cc2)cc1</smiles>

Yellow solid; 60\% yield, $0.060 \mathrm{mmol}, 15.6 \mathrm{mg} ;{ }^{1} \mathrm{H}$ NMR (400 $\left.\mathrm{MHz}, \mathrm{CDCl}_{3}\right) \delta 7.76(\mathrm{dd}, J=9.0,7.1 \mathrm{~Hz}, 4 \mathrm{H}), 6.94(\mathrm{~d}, J=8.8$ $\mathrm{Hz}, 2 \mathrm{H}), 6.70(\mathrm{~d}, J=9.0 \mathrm{~Hz}, 2 \mathrm{H}), 3.87$ (s, 3H), 3.06 (s, 6H) ppm; ${ }^{13} \mathrm{C} \mathrm{NMR}\left(126 \mathrm{MHz}, \mathrm{CDCl}_{3}\right) \delta 194.1,162.3,152.9,132.4,131.9$, $131.7,125.5,113.3,110.7,55.4,40.1 \mathrm{ppm}$.

\section{4-Methoxyacetophenone $(3 w)^{[10]}$}

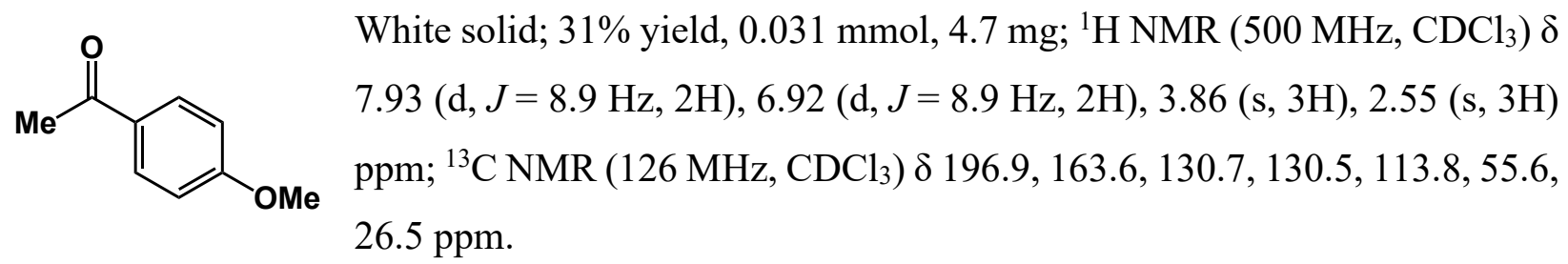

\section{4-Dimethylaminoacetophenone $(3 x)^{[11]}$}<smiles>CC(=O)c1ccc(N(C)C)cc1</smiles>

White solid; 34\% yield, $0.034 \mathrm{mmol}, 5.6 \mathrm{mg}$; ${ }^{1} \mathrm{H}$ NMR (400 MHz, $\mathrm{CDCl}_{3}$ ) $\delta 7.94-7.81(\mathrm{~m}, 2 \mathrm{H}), 6.64(\mathrm{dt}, J=9.2,1.8 \mathrm{~Hz}, 2 \mathrm{H}), 3.04(\mathrm{~d}, J=1.2 \mathrm{~Hz}, 6 \mathrm{H})$, $2.50(\mathrm{~d}, J=1.2 \mathrm{~Hz}, 3 \mathrm{H}) \mathrm{ppm} ;{ }^{13} \mathrm{C} \mathrm{NMR}\left(126 \mathrm{MHz}, \mathrm{CDCl}_{3}\right) \delta$ 196.4, 153.4, $130.5,125.3,110.5,40.0,26.0 \mathrm{ppm}$. 


\section{Cyclohexyl(4-methoxyphenyl)methanone $(3 y)^{[12]}$}

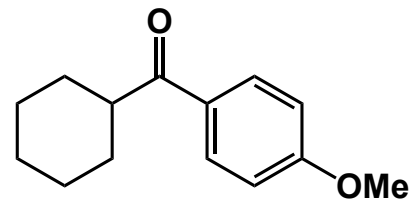

White solid; 31\% yield, $0.031 \mathrm{mmol}, 6.8 \mathrm{mg} ;{ }^{1} \mathrm{H}$ NMR $(400 \mathrm{MHz}$, $\left.\mathrm{CDCl}_{3}\right) \delta 8.03-7.87(\mathrm{~m}, 2 \mathrm{H}), 7.01-6.88(\mathrm{~m}, 2 \mathrm{H}), 3.85(\mathrm{~s}, 3 \mathrm{H}), 3.21$ (tt, $J=11.6,3.2 \mathrm{~Hz}, 1 \mathrm{H}), 1.85$ (dddd, $J=17.6,10.4,4.4,2.4 \mathrm{~Hz}, 4 \mathrm{H})$, $1.72(\mathrm{dtt}, J=13.0,3.4,1.5 \mathrm{~Hz}, 1 \mathrm{H}), 1.54-1.44(\mathrm{~m}, 2 \mathrm{H}), 1.43-1.32(\mathrm{~m}, 2 \mathrm{H}), 1.27$ (tt, $J=12.2$, $3.3 \mathrm{~Hz}, 1 \mathrm{H}) \mathrm{ppm} ;{ }^{13} \mathrm{C} \mathrm{NMR}\left(126 \mathrm{MHz}, \mathrm{CDCl}_{3}\right) \delta 202.4,163.2,130.5,129.2,113.7,55.4,45.3$, 29.5, 26.0, $25.9 \mathrm{ppm}$.

\section{1-(4-Methoxyphenyl)-3-phenylpropan-1-one $(3 z)^{[12]}$}

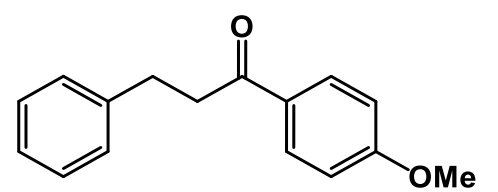

White solid; 41\% yield, $0.041 \mathrm{mmol}, 9.9 \mathrm{mg} ;{ }^{1} \mathrm{H}$ NMR (400 MHz, $\left.\mathrm{CDCl}_{3}\right) \delta 7.95(\mathrm{~d}, J=8.9 \mathrm{~Hz}, 2 \mathrm{H}), 7.34-7.15(\mathrm{~m}, 5 \mathrm{H}), 6.92(\mathrm{~d}, J=$

$8.9 \mathrm{~Hz}, 2 \mathrm{H}), 3.87(\mathrm{~s}, 3 \mathrm{H}), 3.25(\mathrm{dd}, J=8.7,6.8 \mathrm{~Hz}, 2 \mathrm{H}), 3.11-3.00$ $(\mathrm{m}, 2 \mathrm{H}) \mathrm{ppm} ;{ }^{13} \mathrm{C} \mathrm{NMR}\left(126 \mathrm{MHz}, \mathrm{CDCl}_{3}\right) \delta 198.0,163.6,141.6,130.4,130.1,128.6,128.6$, $126.2,113.9,55.6,40.2,30.5 \mathrm{ppm}$.

\section{1-(4-(Dimethylamino)phenyl)-3-phenylpropan-1-one (3aa) ${ }^{[12]}$}

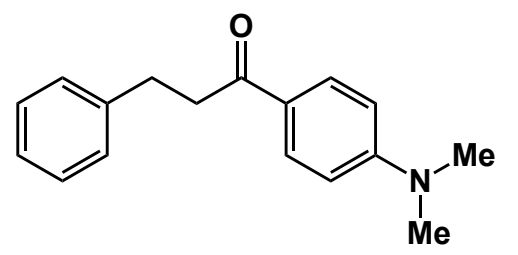

Colorless oil; 17\% yield, $0.017 \mathrm{mmol}, 4.4 \mathrm{mg} ;{ }^{1} \mathrm{H}$ NMR $(400 \mathrm{MHz}$, $\left.\mathrm{CDCl}_{3}\right) \delta 7.97-7.80(\mathrm{~m}, 2 \mathrm{H}), 7.34-7.23(\mathrm{~m}, 4 \mathrm{H}), 7.23-7.16(\mathrm{~m}$,

$1 \mathrm{H}), 6.68-6.60(\mathrm{~m}, 2 \mathrm{H}), 3.25-3.16(\mathrm{~m}, 2 \mathrm{H}), 3.05(\mathrm{~m}, 8 \mathrm{H}) \mathrm{ppm}$;

${ }^{13} \mathrm{C}$ NMR $\left(126 \mathrm{MHz}, \mathrm{CDCl}_{3}\right) \delta 197.6,153.5$ 142.0, 130.4, 128.6,

$128.6,126.1,125.0,110.8,40.2,39.9,30.9$ ppm.

\section{General procedure for control reactions monitored by ${ }^{11} \mathrm{~B}$ NMR of the SMCC reaction}

To an oven-dried 5-mm NMR tube was added acyl MIDA boronate (1a) (0.075 mmol, 1.5 eq.), XPhos Pd G2 (0.005 mmol, $10 \mathrm{~mol} \%)$, and $\mathrm{Cu}(\mathrm{OAc})_{2}(0.075 \mathrm{mmol}, 1.5$ eq. $)$. The tube was transferred to a nitrogen-filled glovebox. $\mathrm{Cs}_{2} \mathrm{CO}_{3}(0.15 \mathrm{mmol}, 3.0$ eq.) and aryl bromide $(0.05$ mmol, 1.0 eq.) were subsequently added in a glove box. DMF (0.1 M) was added. The NMR tube was taken out of the glovebox and was heated to a temperature of $60{ }^{\circ} \mathrm{C}$ for $17 \mathrm{~h} .{ }^{11} \mathrm{~B}$ NMR spectra were obtained in the time intervals indicated. 


\begin{tabular}{ccc|} 
entry & deviation from standard conditions ${ }^{[a]}$ & $\begin{array}{c}\mathbf{1 1}^{11} \mathbf{~ N M R} \text { resonances appeared in the course } \\
\text { of the reaction }\end{array}$ \\
$\mathbf{1}$ & none & $0.47 \mathrm{ppm}$ \\
$\mathbf{2}$ & no XPhos $\mathrm{Pd} \mathrm{G} 2$, no $\mathbf{2 a}$ & $0.47 \mathrm{ppm}$ \\
$\mathbf{3}$ & no $\mathrm{Cu}(\mathrm{OAc})_{2}$ & no conversion \\
$\mathbf{4}$ & only $\mathbf{1 a}$ and $\mathrm{Cu}(\mathrm{OAc})_{2}$ & no conversion \\
$\mathbf{5}$ & only $\mathbf{1 a}$ and $\mathrm{Cs}_{2} \mathrm{CO}_{3}$ & no conversion \\
$\mathbf{6}$ & only $\mathbf{1 a}$ and $\mathrm{CsOAc}$ & no conversion \\
$\mathbf{7}$ & only $\mathbf{1 a}, \mathrm{Cu}(\mathrm{OAc})_{2}$, and $\mathrm{CsOAc}$ & no conversion
\end{tabular}

Table S2. Control reactions monitored by ${ }^{11} \mathrm{~B}$ NMR spectroscopy. ${ }^{[a]}$ Standard conditions: 1a (1.5 eq.), aryl bromide (1.0 eq.), XPhos Pd G2 (10 mol \%), $\mathrm{Cu}(\mathrm{OAc})_{2}$ (1.5 eq.), $\mathrm{Cs}_{2} \mathrm{CO}_{3}$ (3.0 eq.) in DMF (0.1 M), 60 ${ }^{\circ} \mathrm{C}, 16 \mathrm{~h}$.

\section{${ }^{11} B$ NMR spectra of the control reactions of the SMCC reaction}

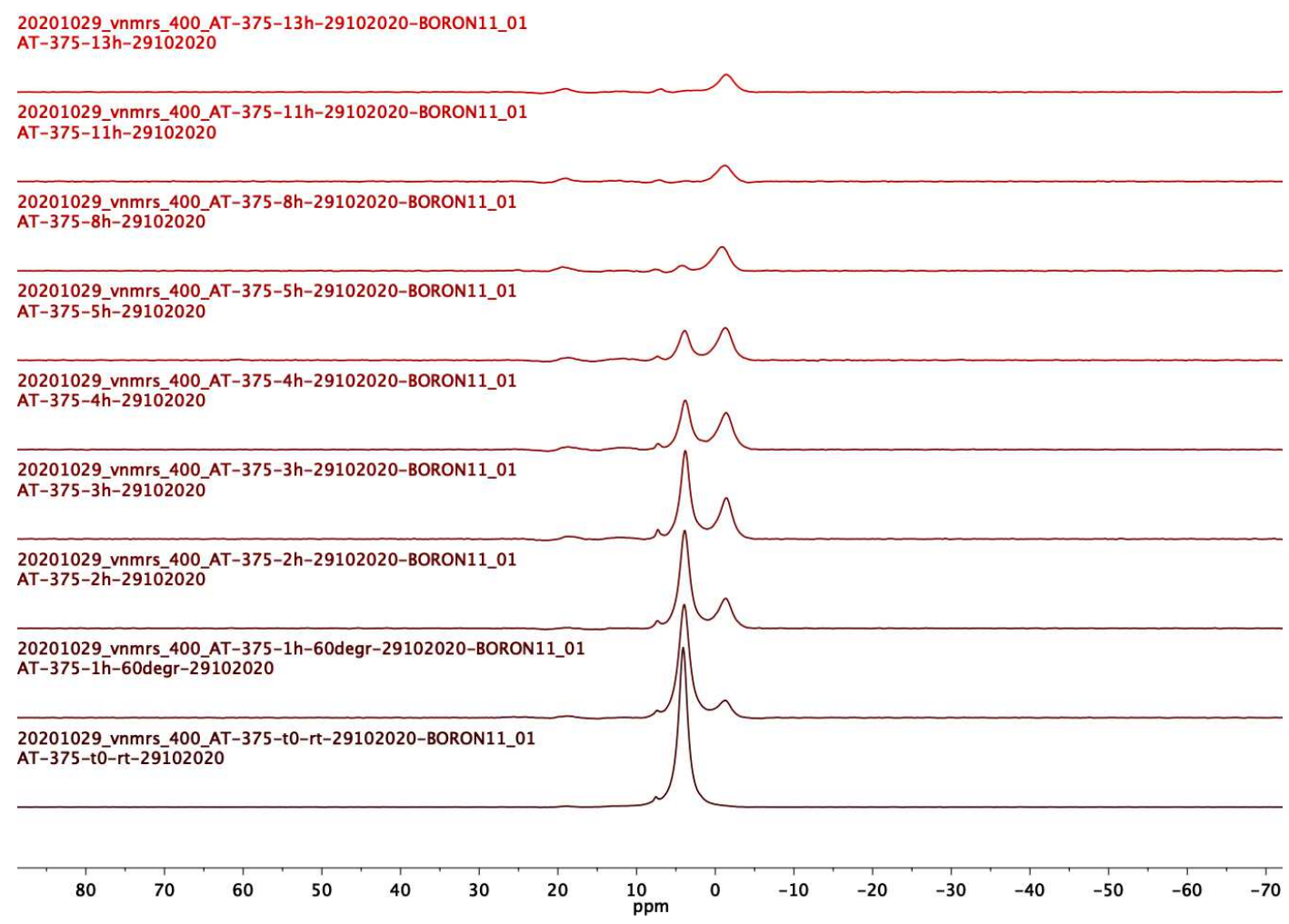

Figure S1. ${ }^{11}$ B NMR spectra of the reaction of MIDA acylboronate 1a under standard conditions. Standard conditions: $1 \mathrm{a}$ (1.5 eq.), 4-bromoanisole (1.0 eq.), XPhos Pd G2 (10 mol \%), $\mathrm{Cu}(\mathrm{OAc})_{2}$ (1.5 eq.), $\mathrm{Cs}_{2} \mathrm{CO}_{3}$ (3.0 eq.) in DMF (0.1 M), $60^{\circ} \mathrm{C}$. 


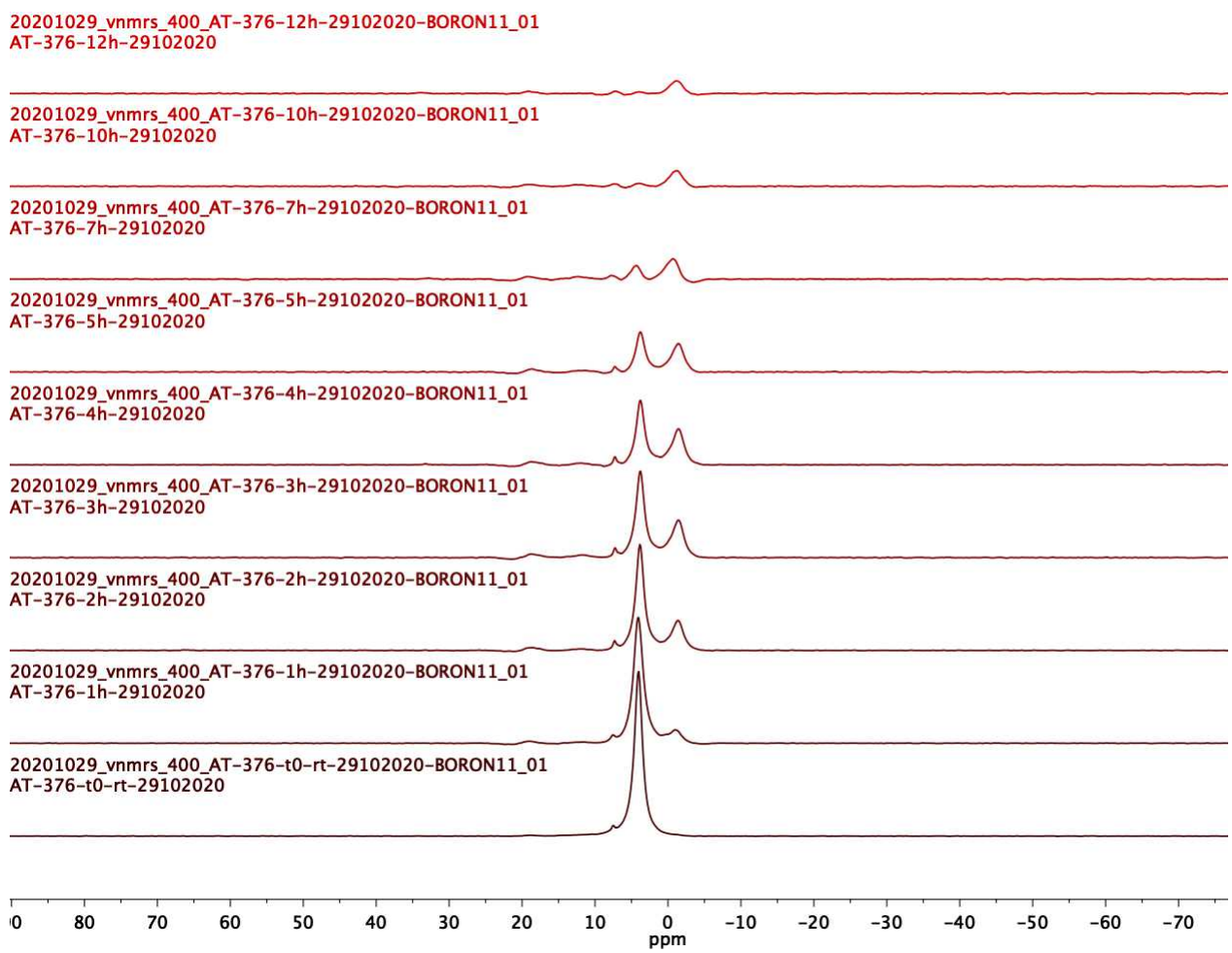

Figure S2. ${ }^{11}$ B NMR spectra of the reaction of MIDA acylboronate 1a without Pd catalyst. Reaction conditions: 1a (1.5 eq.), $\mathrm{Cu}(\mathrm{OAc})_{2}$ (1.5 eq.), $\mathrm{Cs}_{2} \mathrm{CO}_{3}$ (3.0 eq.) in $\mathrm{DMF}(0.1 \mathrm{M}), 60^{\circ} \mathrm{C}$.

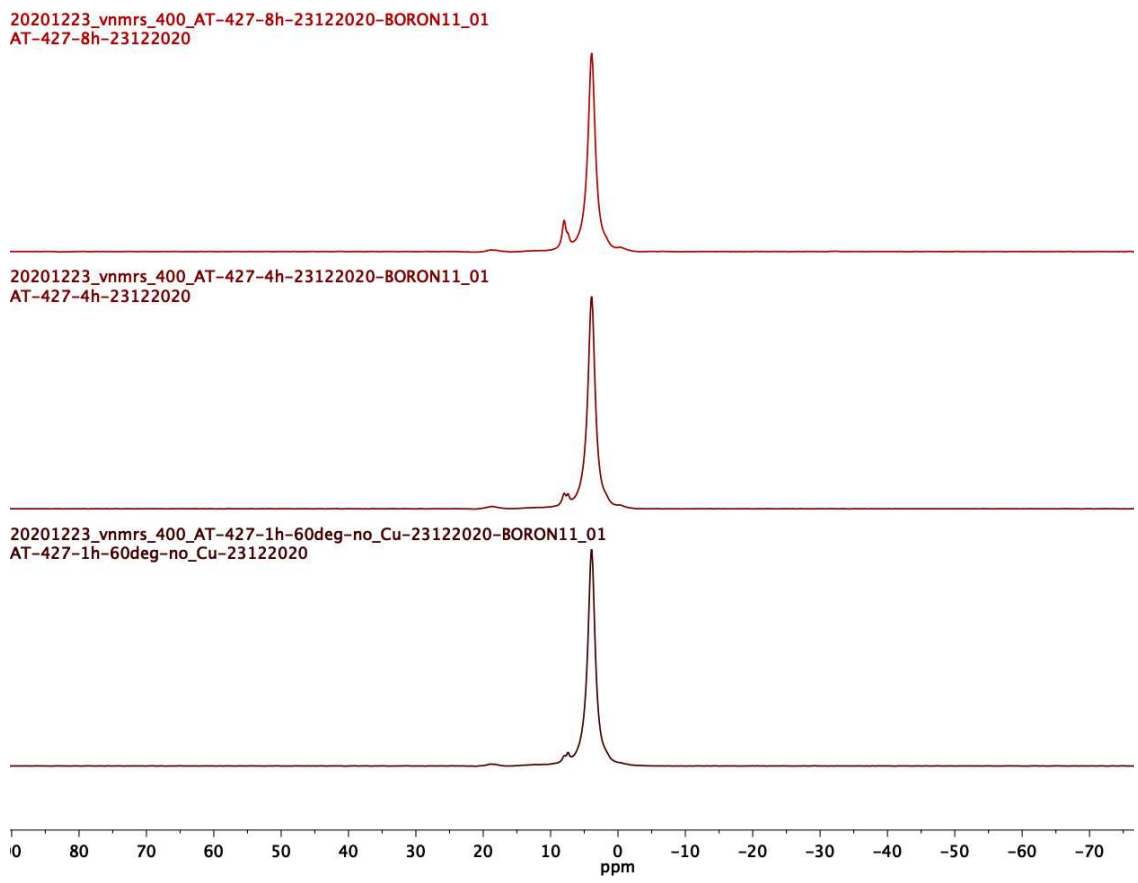

Figure S3. ${ }^{11}$ B NMR spectra of the reaction of MIDA acylboronate 1a with no copper additive. Reaction conditions: $1 \mathrm{a}$ (1.5 eq.), 4-bromoanisole (1.0 eq.), XPhos Pd G2 (10 mol \%), $\mathrm{Cs}_{2} \mathrm{CO}_{3}\left(3.0\right.$ eq.) in DMF $(0.1 \mathrm{M}), 60^{\circ} \mathrm{C}$. 


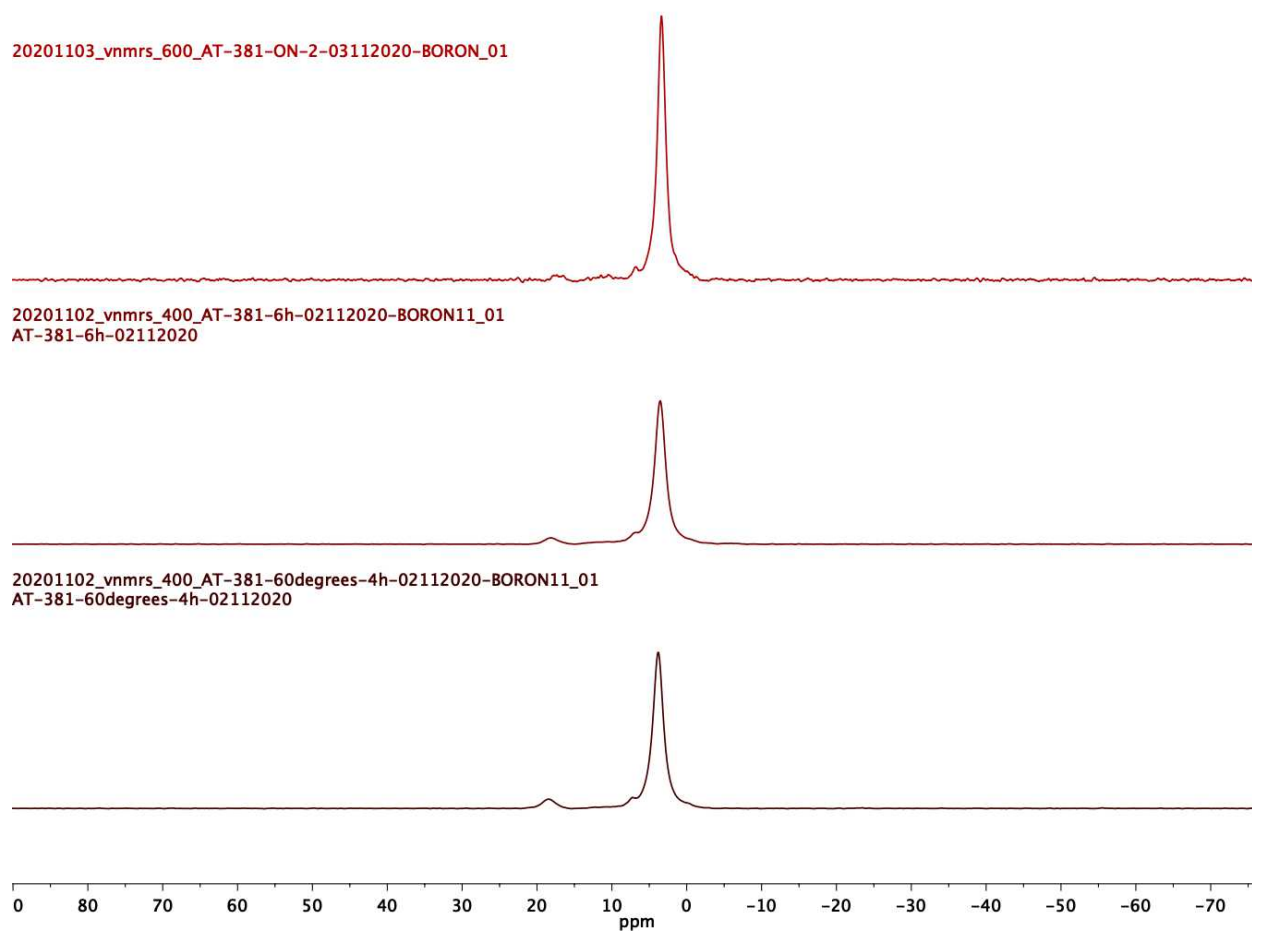

Figure S4. ${ }^{11} \mathrm{~B}$ NMR spectra of the reaction of MIDA acylboronate 1a with $\mathrm{Cu}(\mathrm{OAc})_{2}$ only. Reaction conditions: 1a (1.5 eq.), $\mathrm{Cu}(\mathrm{OAc})_{2}\left(1.5\right.$ eq.) in $\mathrm{DMF}(0.1 \mathrm{M}), 60^{\circ} \mathrm{C}$.

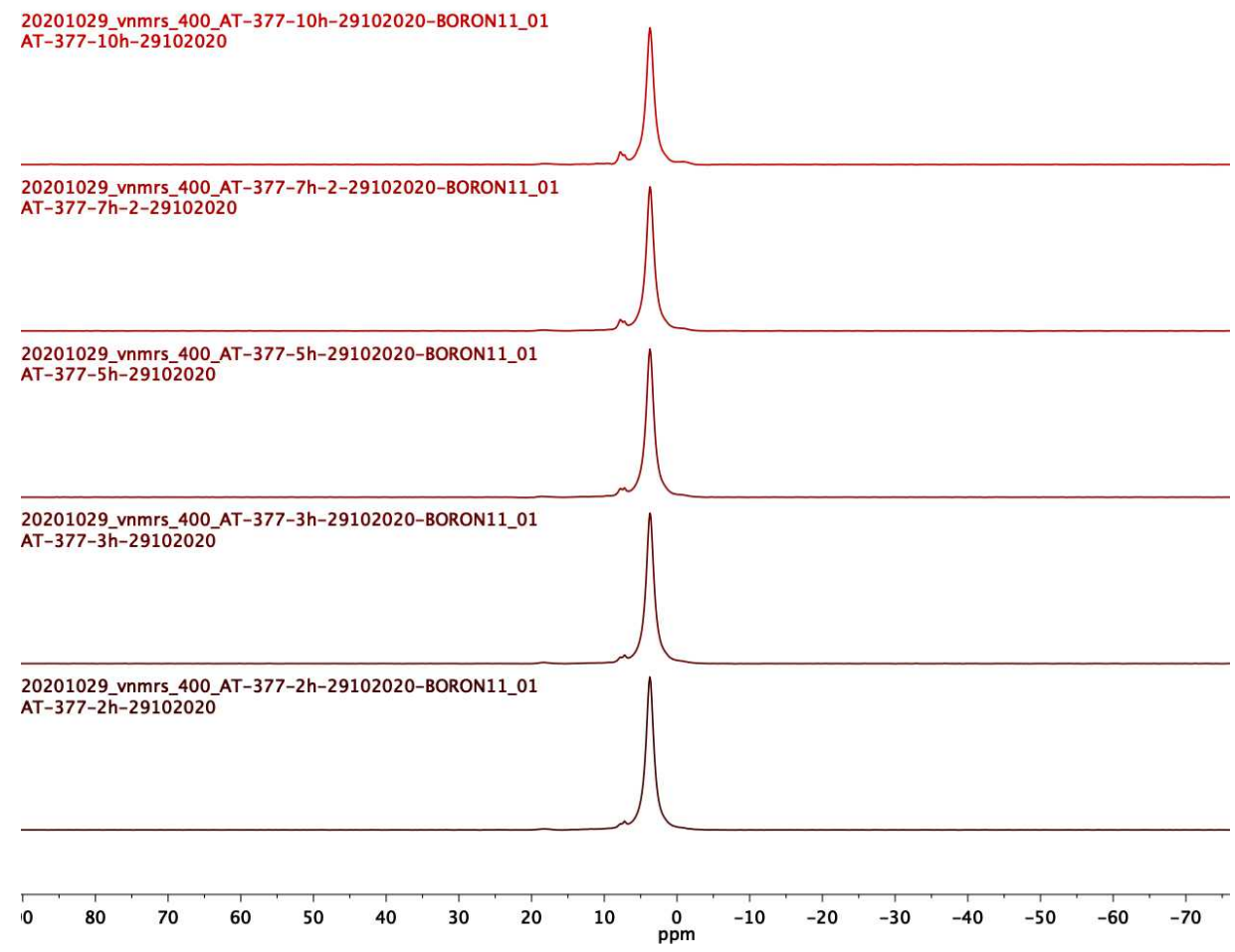

Figure S5. ${ }^{11}$ B NMR spectra of the reaction of MIDA acylboronate 1a with base only. Reaction conditions: 1a (1.5 eq.), $\mathrm{Cs}_{2} \mathrm{CO}_{3}$ (3.0 eq.) in $\mathrm{DMF}(0.1 \mathrm{M}), 60^{\circ} \mathrm{C}$. 
20201106_vnmrs_400_AT-391-ON-evening-06112020-BORON11_01

AT-391-ON-evening-06112020

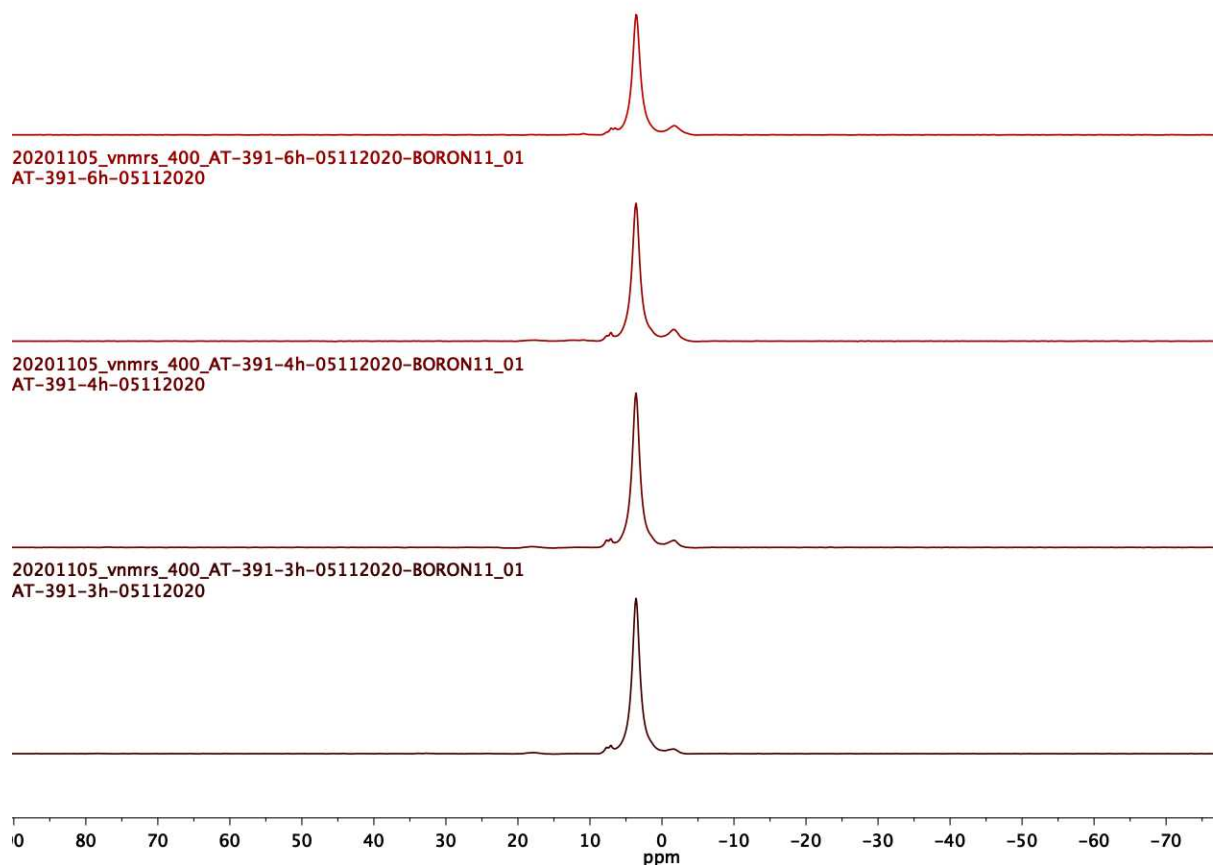

Figure S6. ${ }^{11} \mathrm{~B}$ NMR spectra of the reaction of MIDA acylboronate 1a with only CsOAc. Reaction conditions: 1a (1.5 eq.), $\mathrm{CsOAc}\left(3.0\right.$ eq.) in $\mathrm{DMF}(0.1 \mathrm{M}), 60^{\circ} \mathrm{C}$.

20201120_vnmrs_400_AT-414-ON-2-20112020-BORON11_01 AT $-414-\mathrm{ON}-2-20112020$

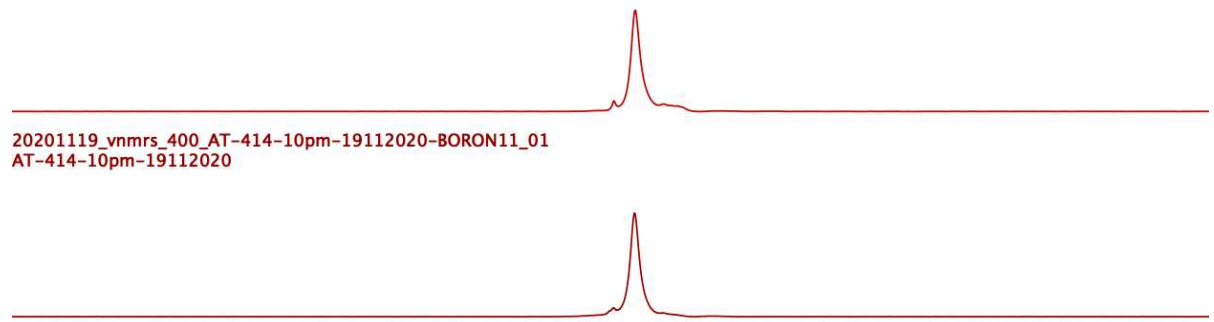

20201119_vnmrs_400_AT-414-8pm-19112020-BORON11_01 AT-414-8pm-1911202̄o

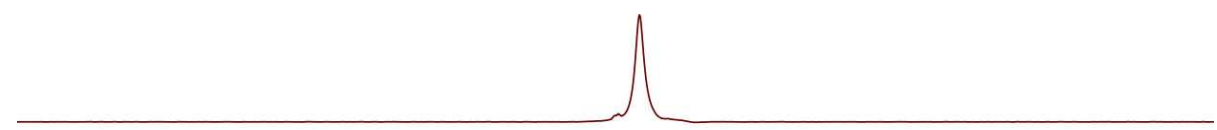

20201119_vnmrs_600_AT-414-6_30pm-19112020-BORON_01

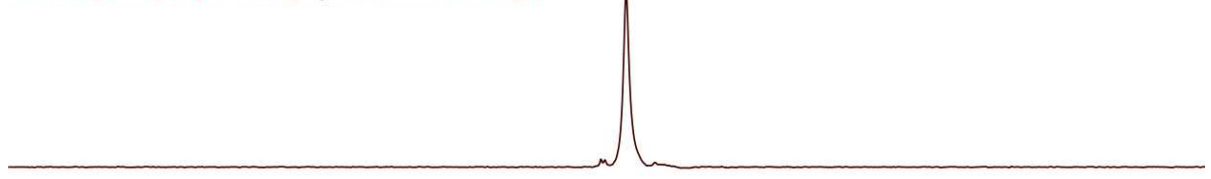

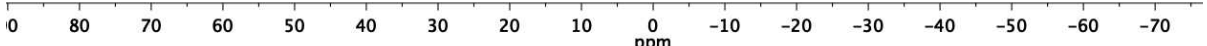

Figure S7. ${ }^{11}$ B NMR spectra of the reaction of MIDA acylboronate 1a with CsOAc as a base. Reaction conditions: $1 \mathrm{a}$ (1.5 eq.), $\mathrm{Cu}(\mathrm{OAc})_{2}$ (1.5 eq.), $\mathrm{CsOAc}\left(3.0\right.$ eq.) in $\mathrm{DMF}(0.1 \mathrm{M}), 60^{\circ} \mathrm{C}$. 


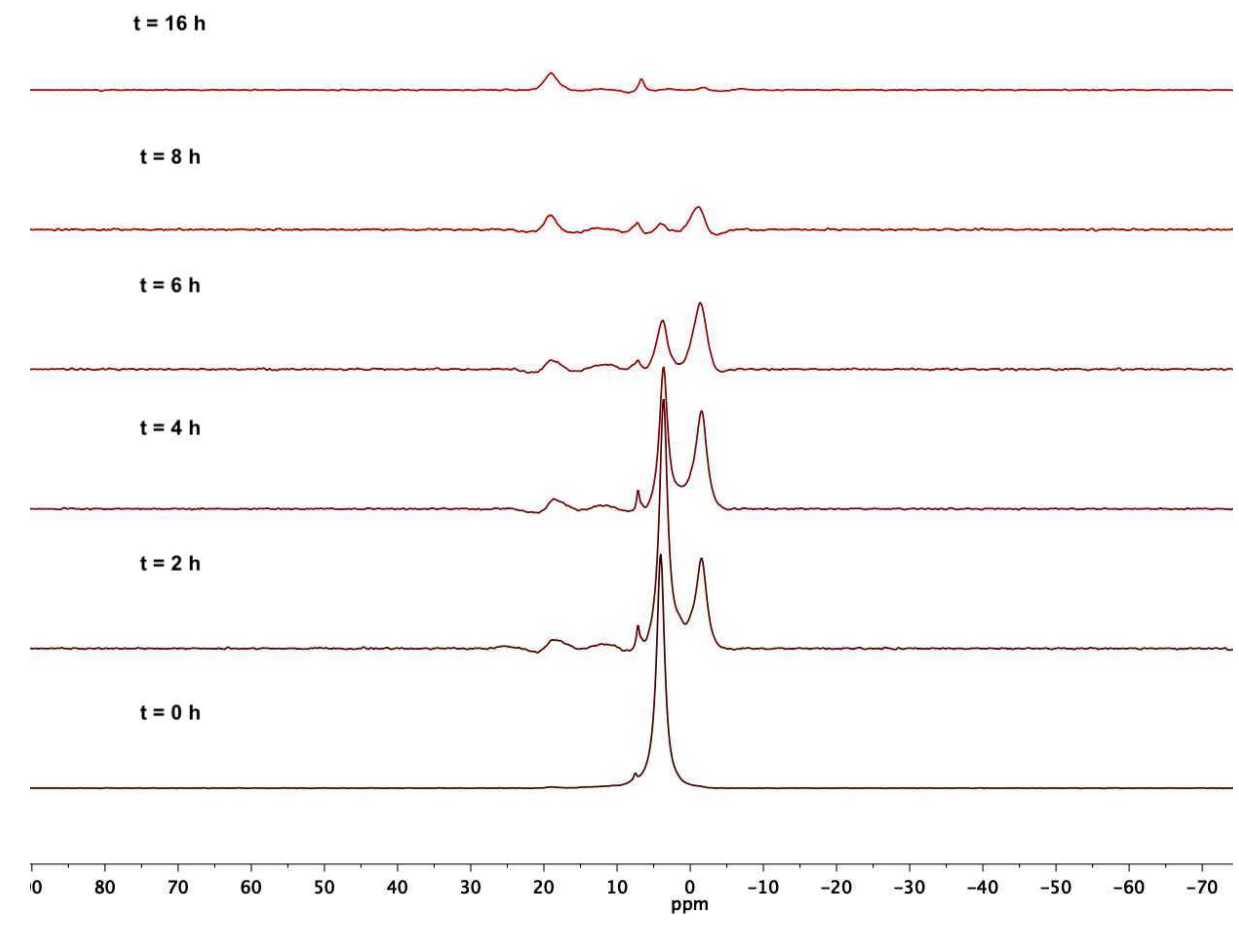

Figure S8. ${ }^{11}$ B NMR spectra of the reaction of MIDA acylboronate 1a (0.95 eq.) under standard conditions. Reaction conditions: 1a (0.95 eq.), 4-bromoanisole (1.0 eq.), XPhos Pd G2 (10 mol \%), $\mathrm{Cu}(\mathrm{OAc})_{2}$ (1.5 eq.), $\mathrm{Cs}_{2} \mathrm{CO}_{3}(3.0$ eq.) in $\operatorname{DMF}(0.1 \mathrm{M}), 60^{\circ} \mathrm{C}$.

General procedure for the stoichiometric reaction monitored by ${ }^{31} \mathrm{P}$ NMR of the SMCC reaction

To an oven-dried 5-mm NMR tube was added acyl MIDA boronate (1a) $(0.075 \mathrm{mmol}, 1.5 \mathrm{eq}$.$) ,$ XPhos Pd G2 (0.05 mmol, 1 eq.), and $\mathrm{Cu}(\mathrm{OAc})_{2}(0.075 \mathrm{mmol}, 1.5$ eq.). The tube was transferred to a nitrogen-filled glovebox. $\mathrm{Cs}_{2} \mathrm{CO}_{3}(0.15 \mathrm{mmol}, 3.0 \mathrm{eq}$.) and aryl bromide (0.05 mmol, $1.0 \mathrm{eq}$.) were subsequently added in a glovebox. DMF $(0.1 \mathrm{M})$ was added. The NMR tube was taken out of the glovebox and was heated to a temperature of $60{ }^{\circ} \mathrm{C}$ for $17 \mathrm{~h} .{ }^{31} \mathrm{P}$ NMR spectra were obtained in the time intervals indicated. 


\section{${ }^{31} \mathrm{P}$ NMR and mass spectrometry spectra of the stoichiometric reactions of the SMCC reaction}

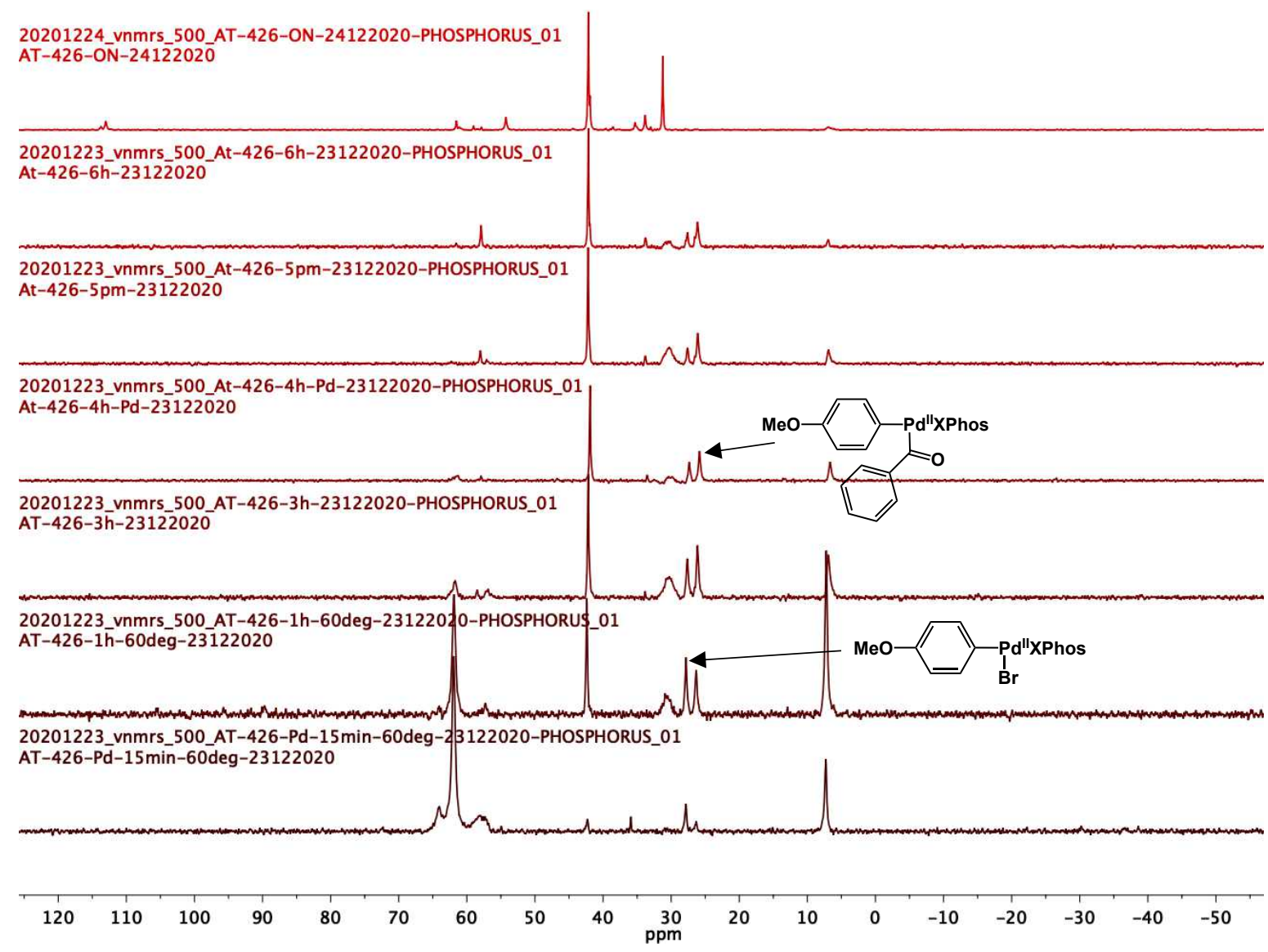

Figure S9. ${ }^{31} \mathrm{P}$ NMR spectra of the stoichiometric reaction of MIDA acylboronate 1a (1.5 eq.), 4-bromoanisole (1.0 eq.), XPhos Pd G2 (1.0 eq.), $\mathrm{Cu}(\mathrm{OAc})_{2}\left(1.5\right.$ eq.), $\mathrm{Cs}_{2} \mathrm{CO}_{3}$ (3.0 eq.) in $\mathrm{DMF}(0.1 \mathrm{M}), 60^{\circ} \mathrm{C}$. 

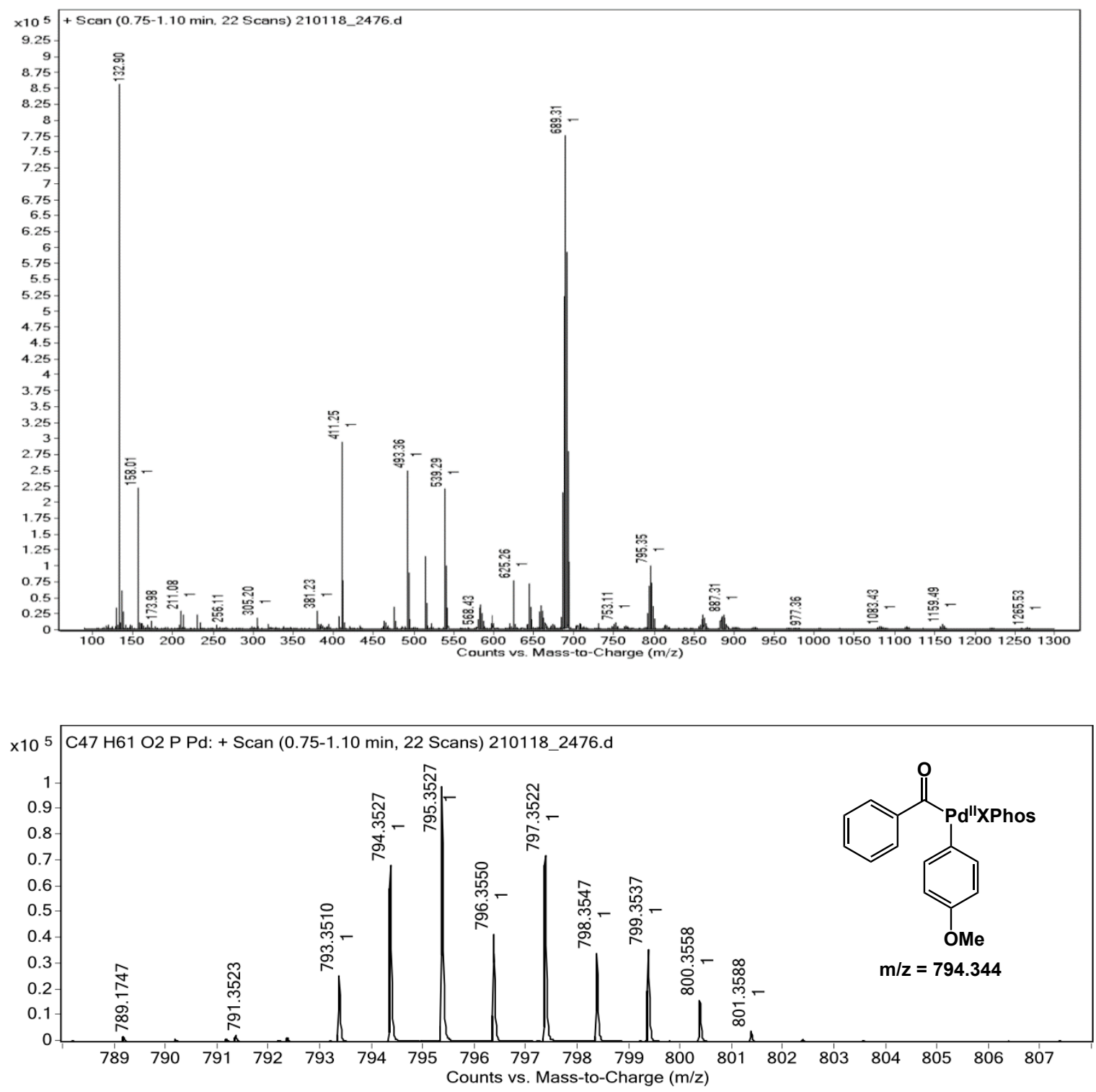

Figure S10. Mass spectrum of the crude reaction of MIDA acylboronate 1a and 4-bromoanisole showing the peak attributable to a transmetalation complex $(\mathrm{m} / \mathrm{z}=794.344)$. 


\section{References:}

1. Taguchi, J.; Ikeda, T.; Takahashi, R.; Sasaki, I.; Ogasawara, Y.; Dairi, T.; Kato, N.; Yamamoto, Y.; Bode, J. W.; Ito, H. Angew. Chem., Int. Ed. 2017, 56, 13847 - 13851.

2. Diaz, D. B.; Scully, C. C.; Liew, S. K.; Adachi, S.; Trinchera, P.; St. Denis, J. D.; Yudin, A. K. Angew. Chem., Int. Ed. 2016, 55, 12659 - 12663.

3. Zhang, Y.; Wang, Z.; Tang, Z.; Luo, Z.; Wu, H.; Liu, T.; Zhu, Y.; Zeng, Z. Eur. J. Org. Chem. 2020, $11,1620-1628$.

4. Chenniappan, V. K.; Silwal, S.; Rahaim, R. J. ACS Catal. 2018, 8, 4539 - 4544.

5. Zhong, Y.; Han, W. Chem. Commun. 2014, 50, 3874 - 3877.

6. Liu, C.; Lalancette, R.; Szostak, R.; Szostak, M. Org. Lett. 2019, 21, 7976 - 7981.

7. Lei, P.; Meng, G.; Ling, Y.; An, J.; Nolan, S. P.; Szostak, M. Org. Lett. 2017, 19, 6510 - 6513.

8. Oh, K. W.; Choi, H.-M.; Kim, J. M.; Park, J. H.; Park, I. S. Textile Research Journal 2014, 84, $808-818$.

9. Li, H.; Xu, Y.; Shi, E.; Wei, W.; Suo, X.; Wan, X. Chem. Commun. 2011, 47, 7880 - 7882.

10. Nguyen, J. D.; Matsuura, B. S.; Stephenson, C. R. J. J. Am. Chem. Soc. 2014, 136, 1218 1221.

11. Pandey, G.; Tiwari, S. K.; Singh, B.; Vanka, K.; Jain, S. Chem. Commun. 2017, 53, 12337 12340.

12. Yu, C. G.; Matsuo, Y. Org. Lett. 2020, 22, $950-955$. 
(4-methoxyphenyl)(phenyl)methanone (3a)

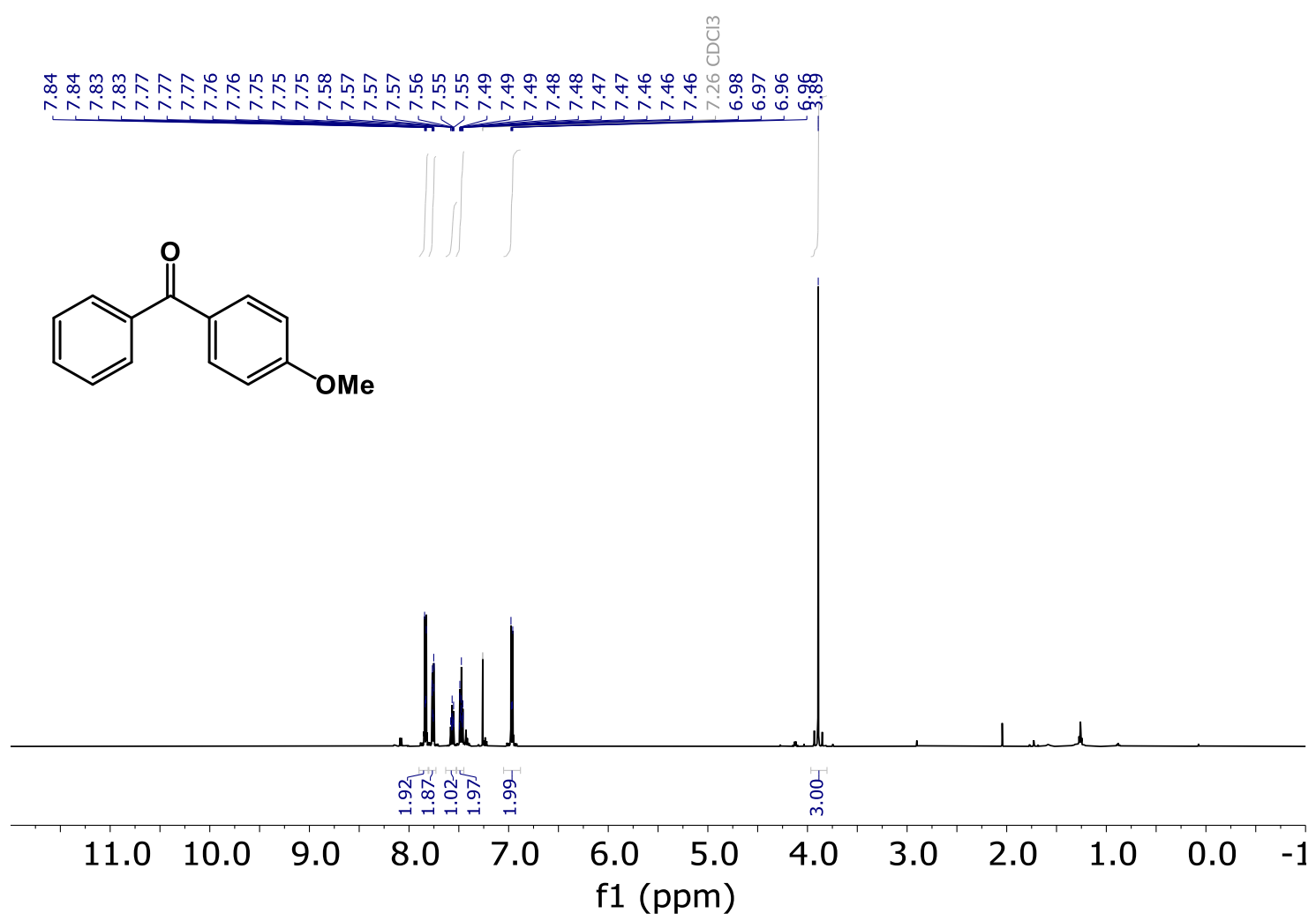

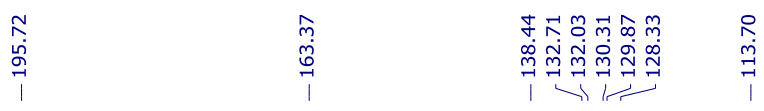<smiles>COc1ccc(C(=O)c2ccccc2)cc1</smiles>

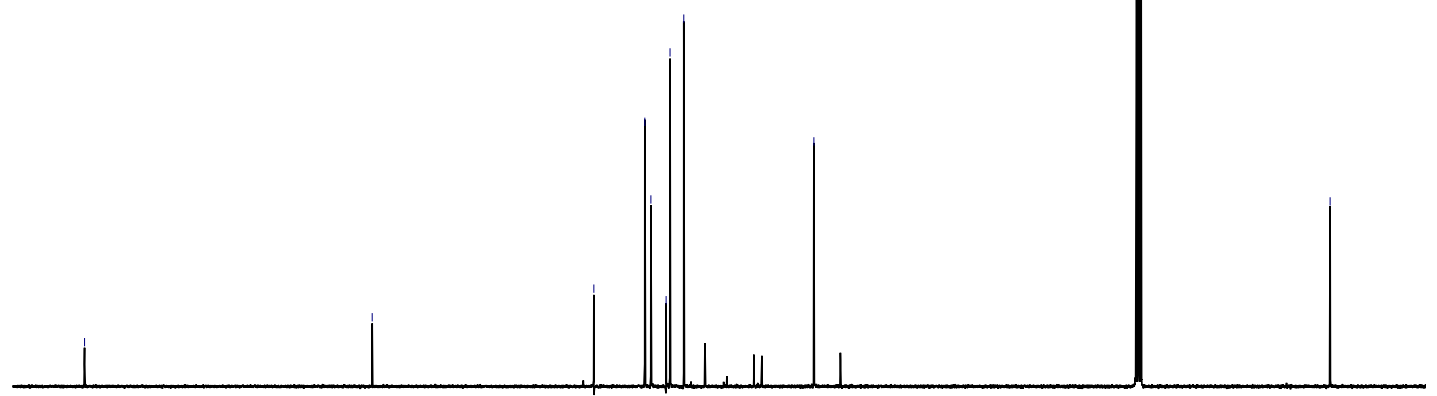

$\begin{array}{lllllllllllllllll}200 & 190 & 180 & 170 & 160 & 150 & 140 & \begin{array}{l}130 \\ \mathrm{f}(\mathrm{ppm})\end{array} & 110 & 100 & 90 & 80 & 70 & 60 & 50\end{array}$ 


\section{(3-methoxyphenyl)(phenyl)methanone (3b)}

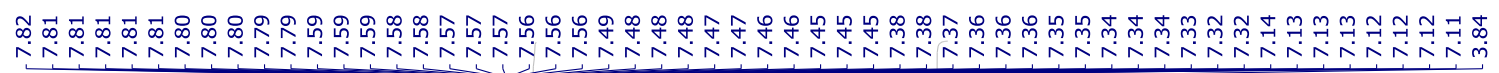<smiles>COc1cccc(C(=O)c2ccccc2)c1</smiles>

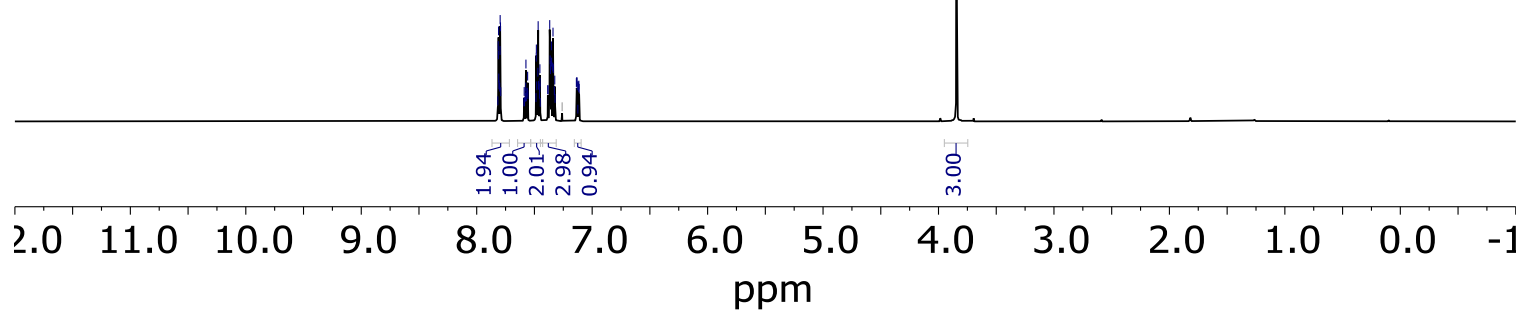<smiles>COc1cccc(C(=O)c2ccccc2)c1</smiles>

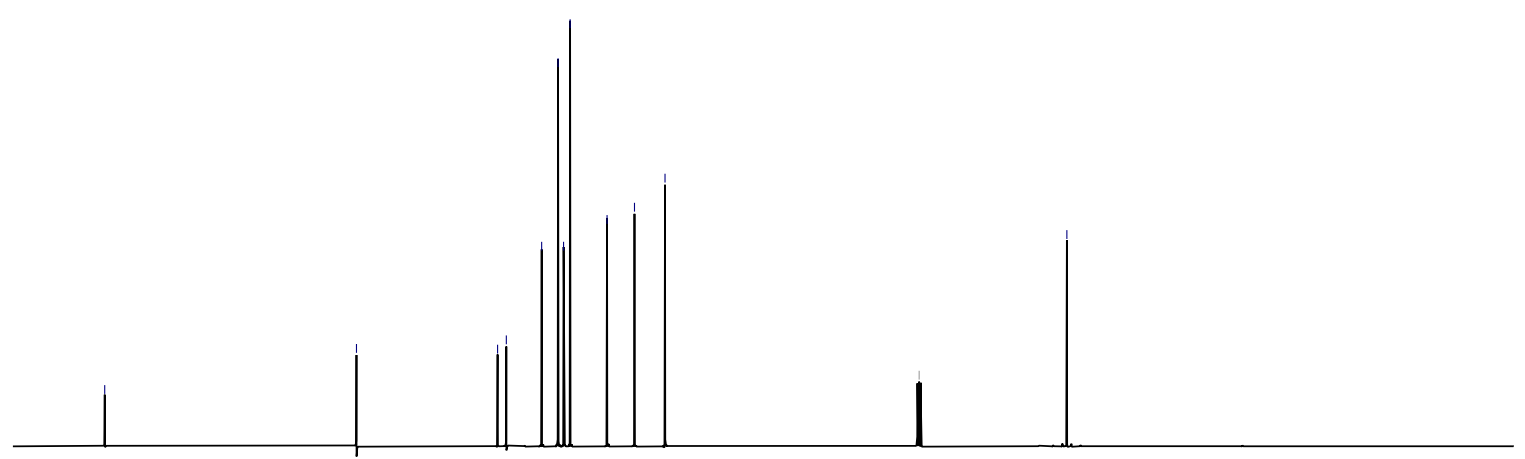

\begin{tabular}{cccccccccccc}
\hline 10 & 190 & 170 & 150 & 130 & 110 & 90 & 70 & 50 & 30 & 10 & $-:$
\end{tabular}




\section{(2-methoxyphenyl)(phenyl)methanone (3c)}
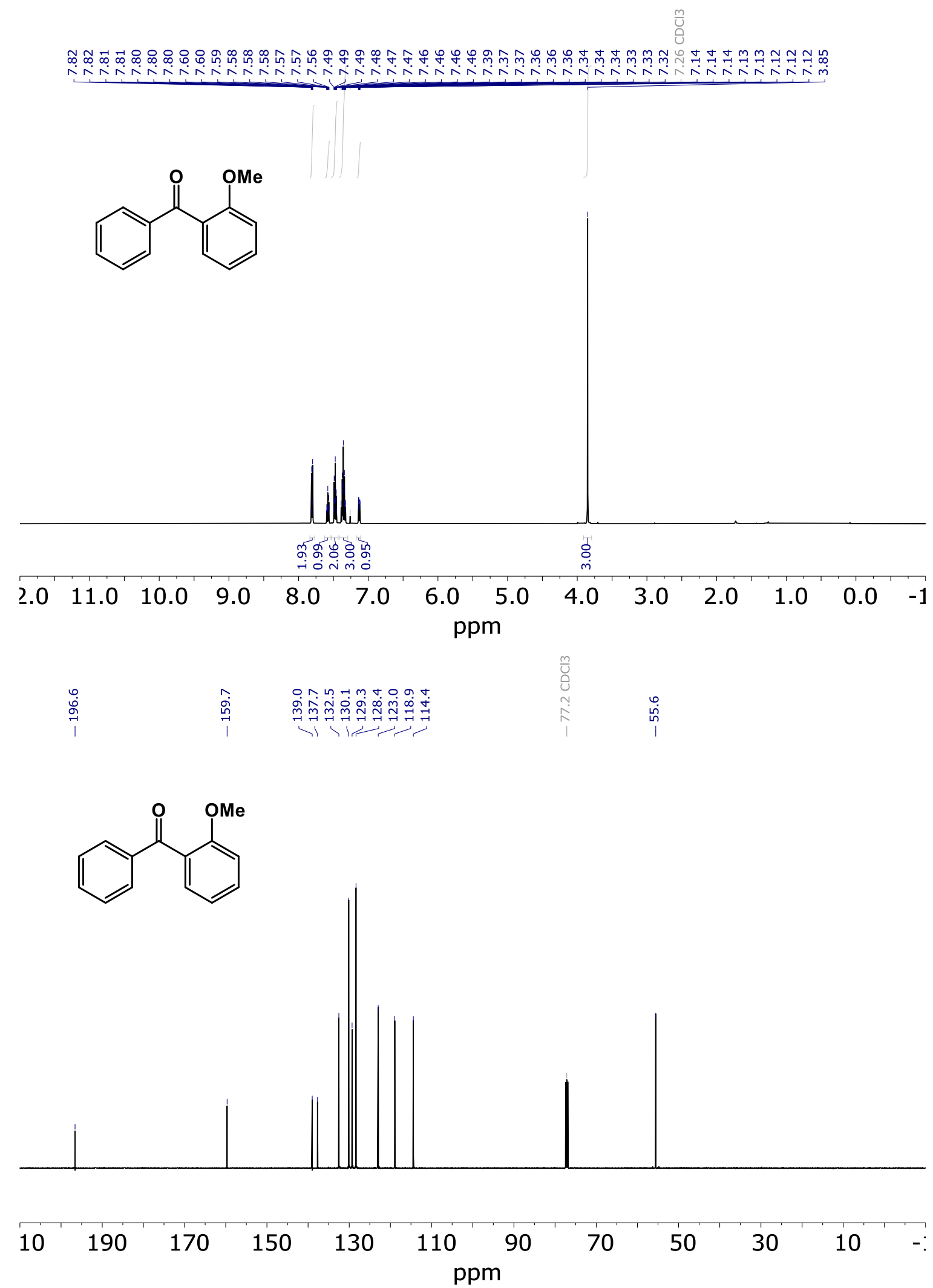

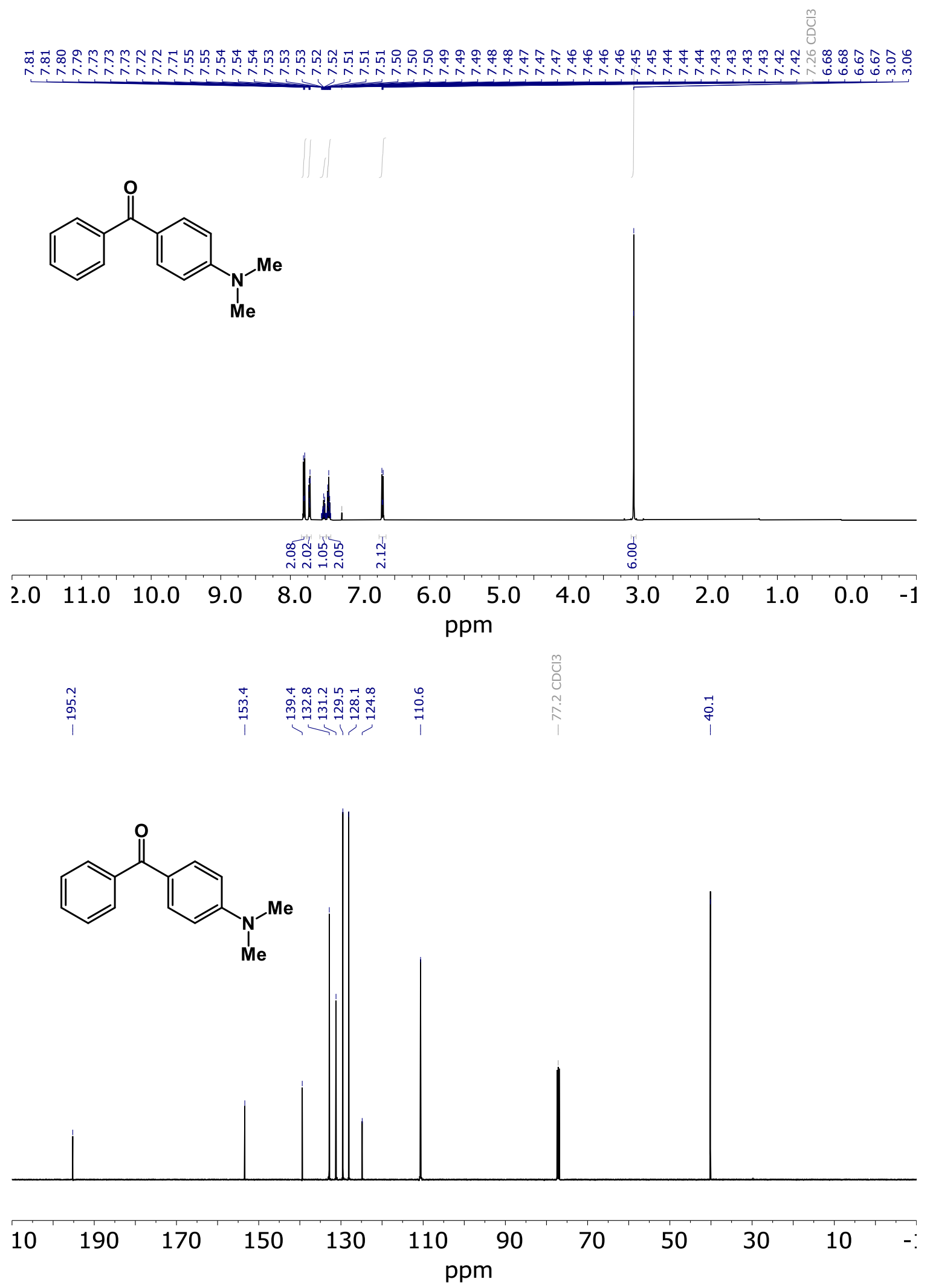


\section{(3,4-dimethoxyphenyl)(phenyl)methanone (3e)}

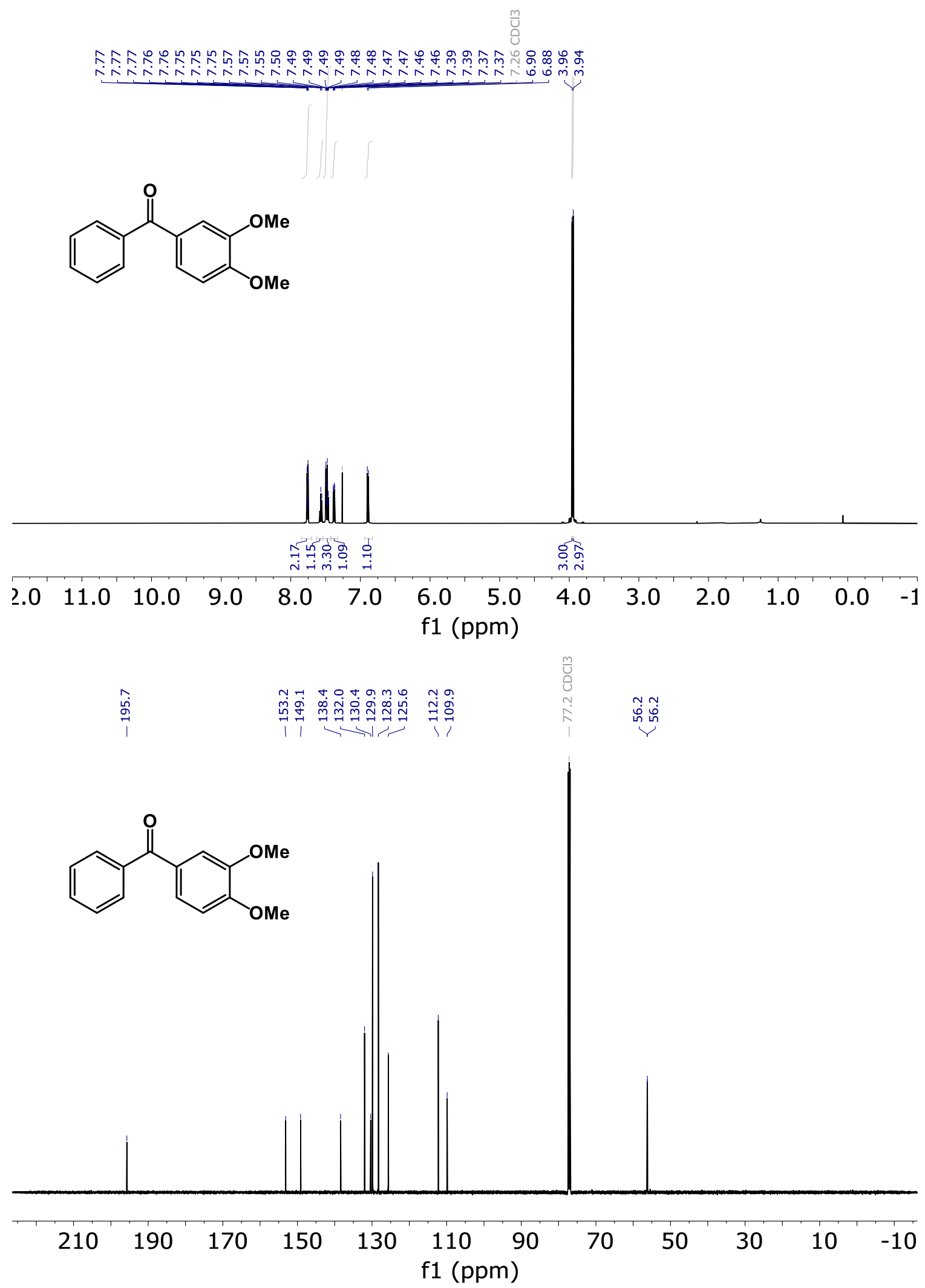


phenyl(p-tolyl)methanone (3f)
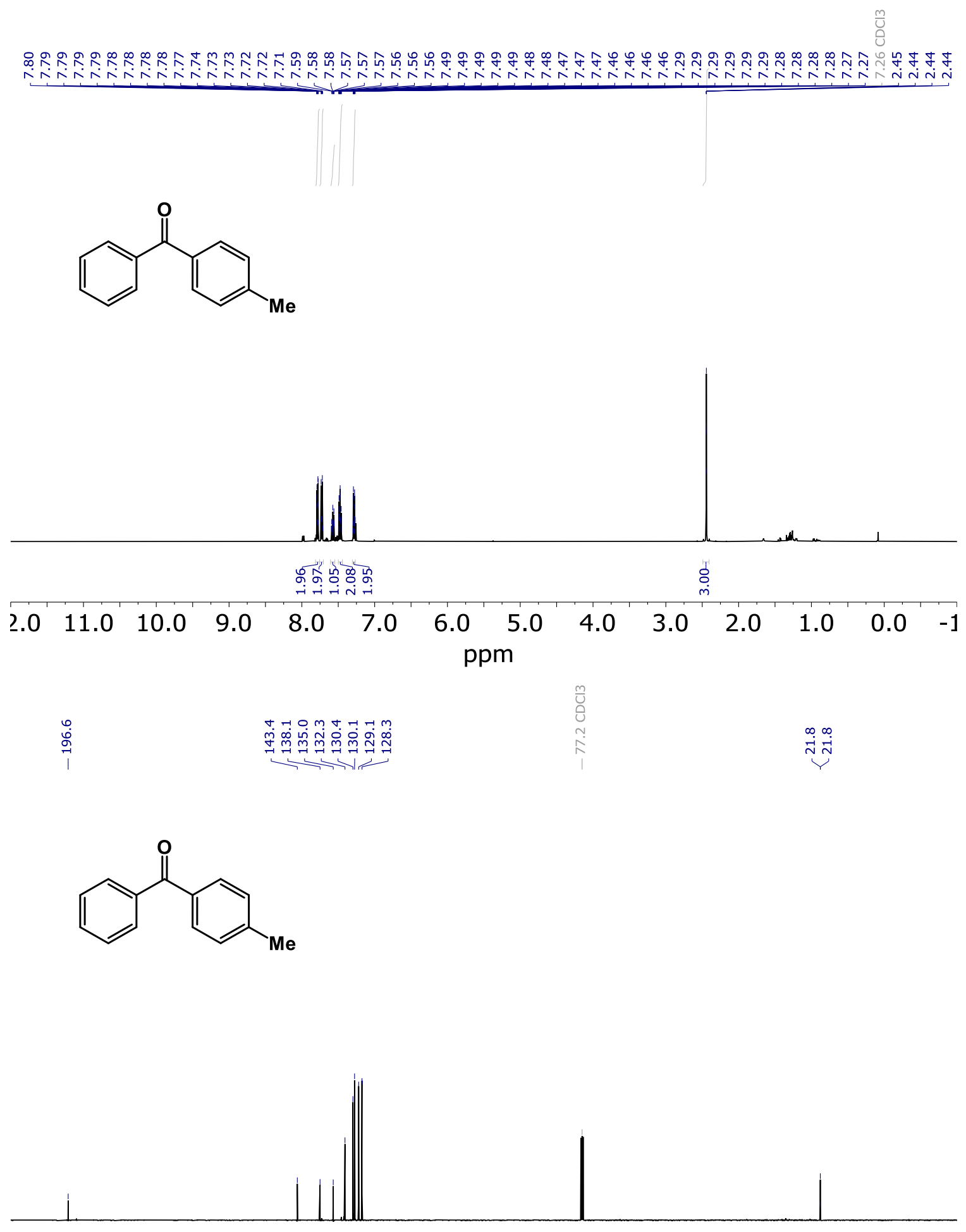

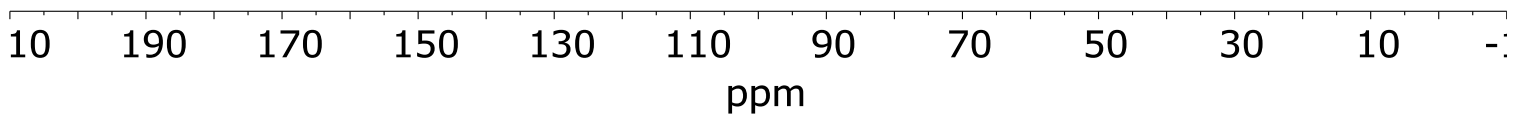




\section{phenyl(o-tolyl)methanone (3g)}
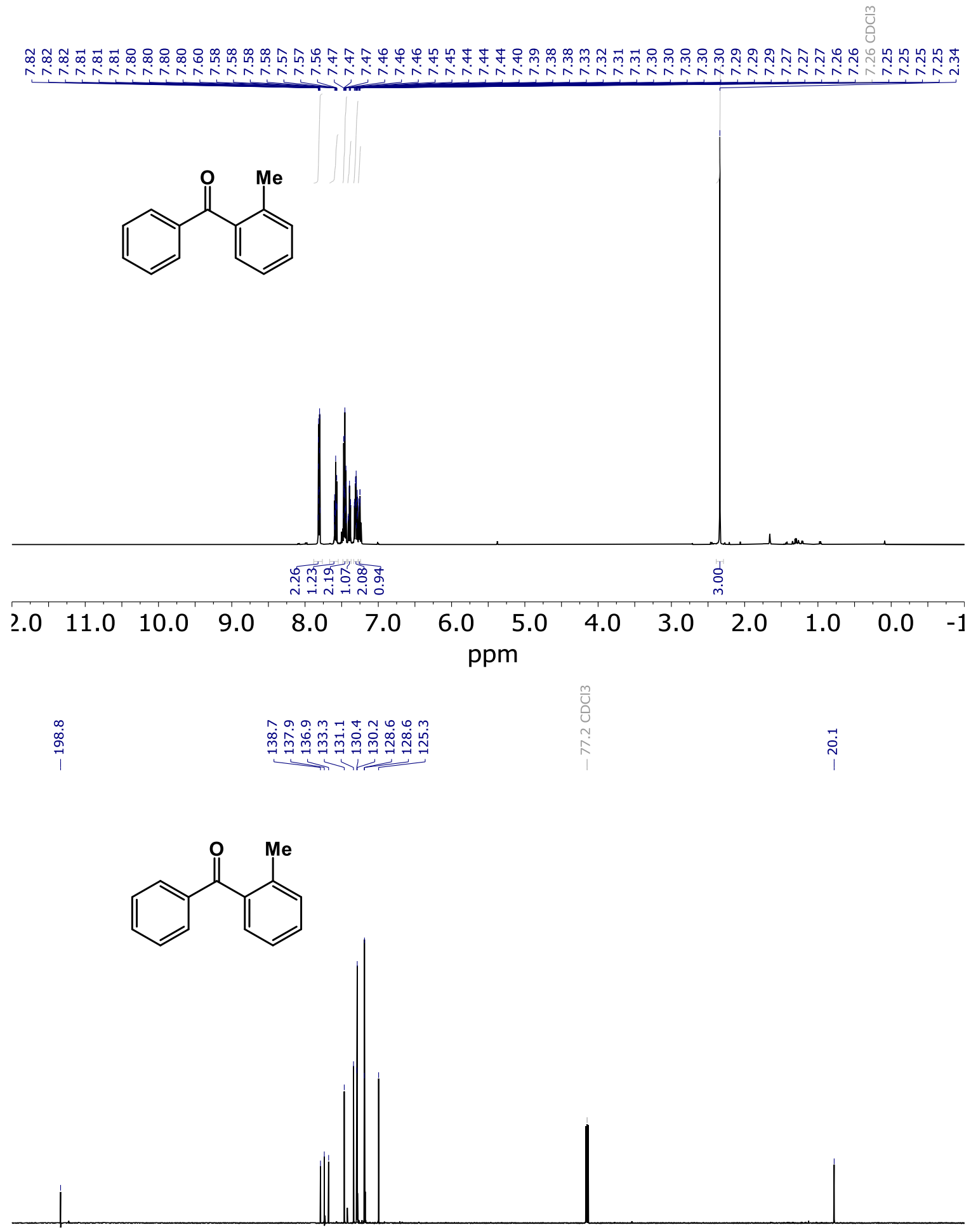

$200 \quad 180 \quad 160 \quad 140 \quad 120 \begin{gathered}100 \\ \mathrm{ppm}\end{gathered}$




\section{(2,6-dimethylphenyl)(phenyl)methanone (3h)}

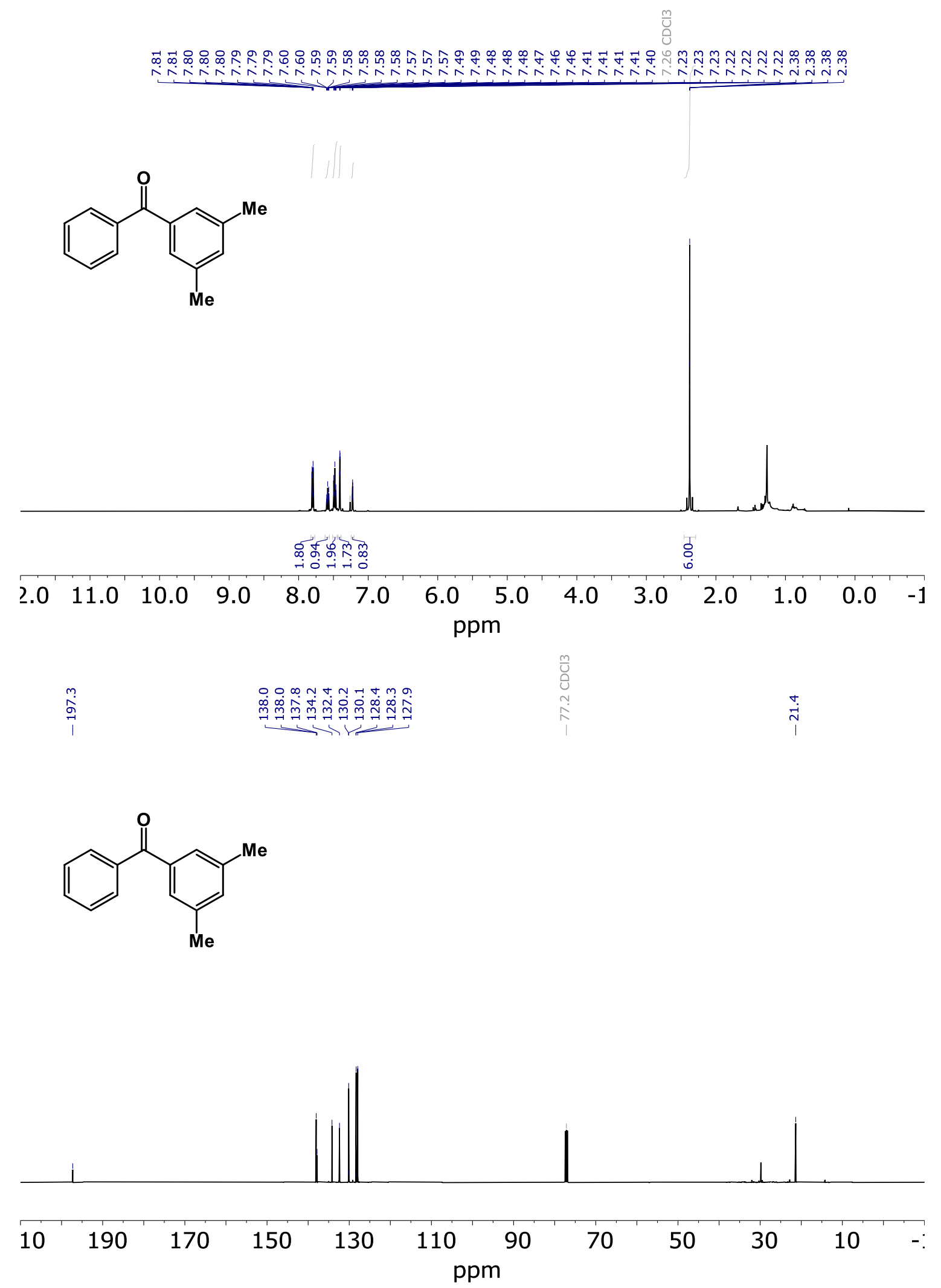


mesityl(phenyl)methanone (3i)

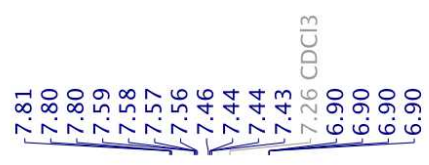<smiles>Cc1cc(C)c(C(=O)c2ccccc2)c(C)c1</smiles>
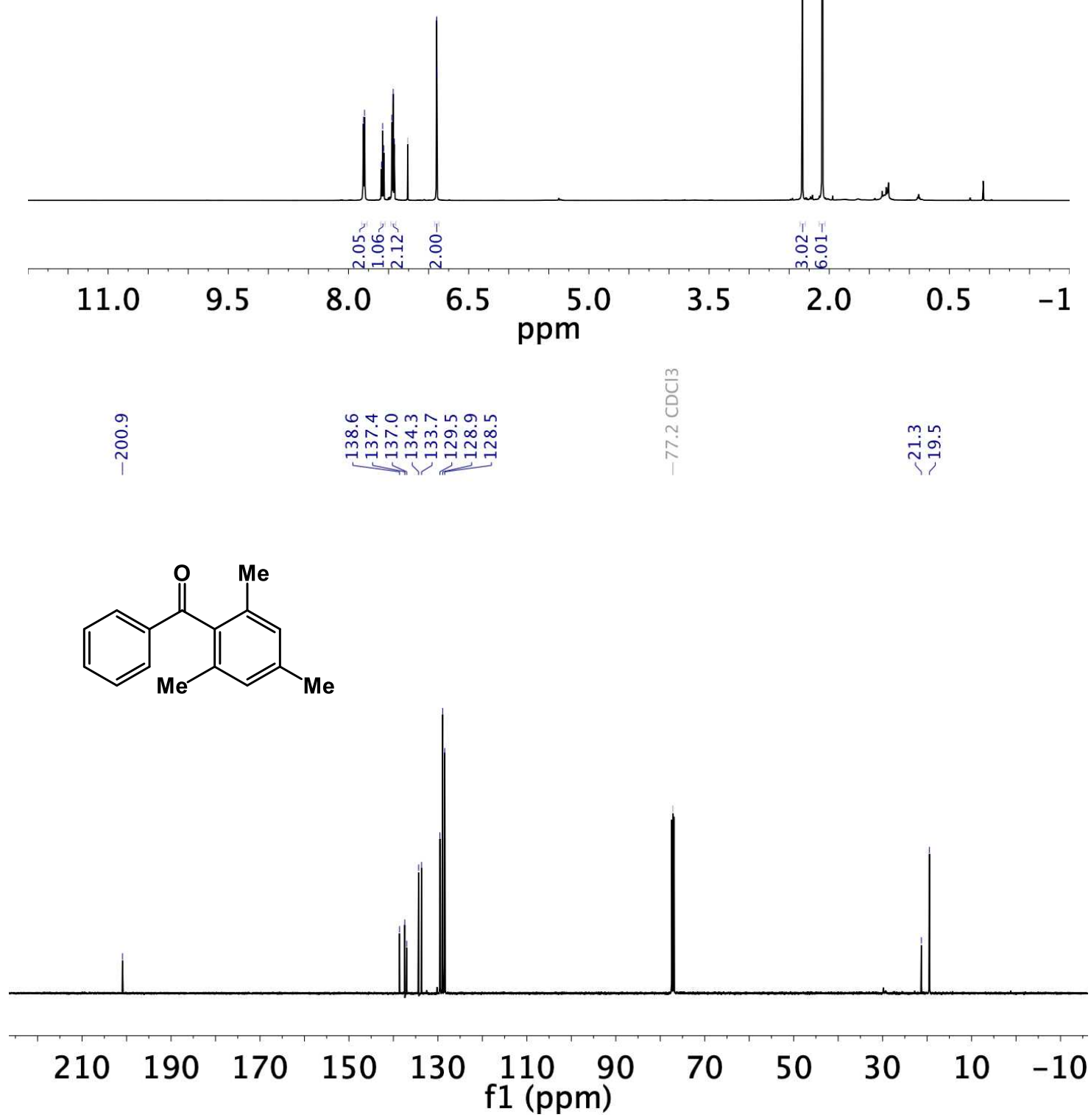
benzophenone (3j)

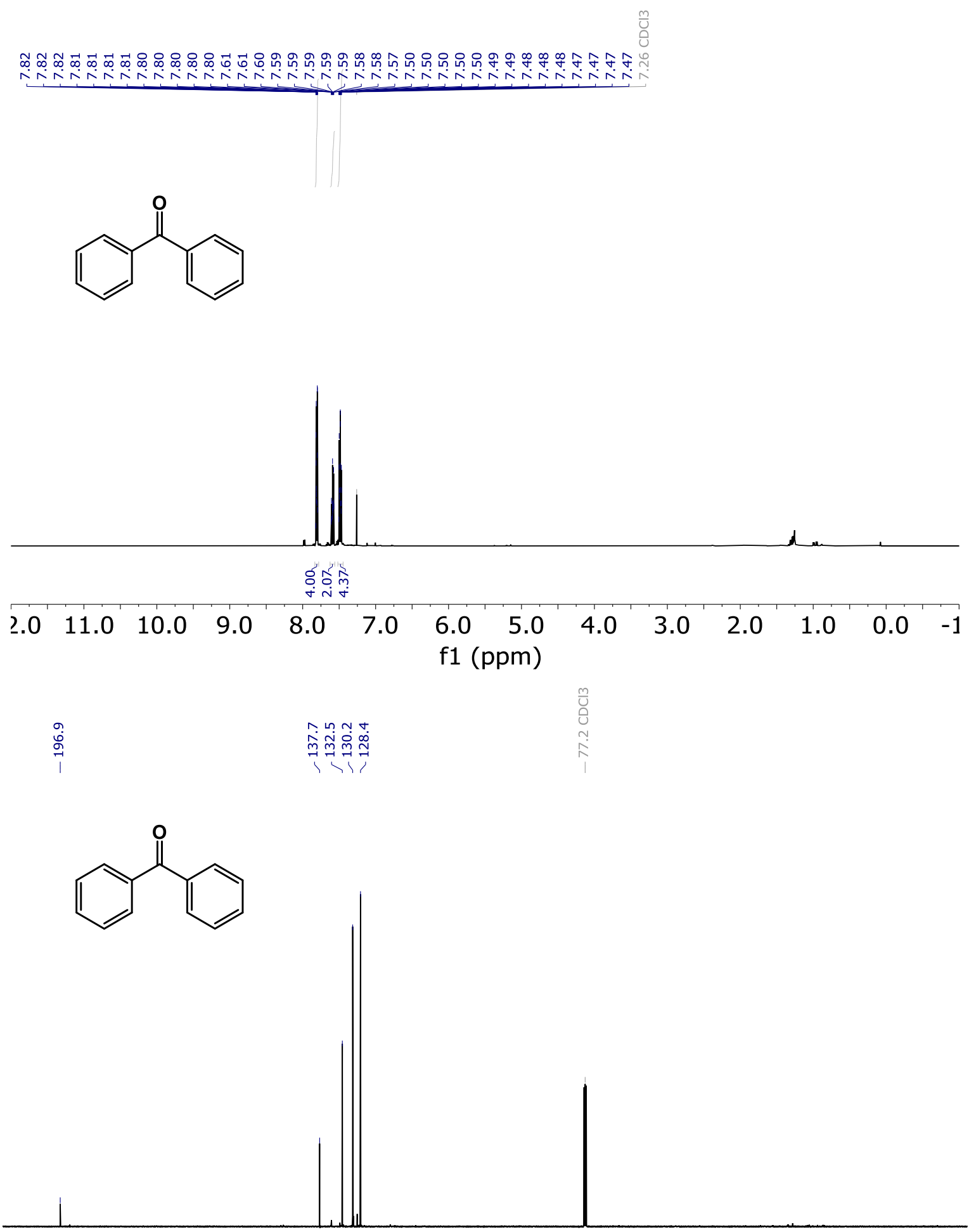

\begin{tabular}{llllllllllll}
\hline 10 & 190 & 170 & 150 & 130 & 110 & 90 & 70 & 50 & 30 & 10 & -:
\end{tabular} f1 (ppm) 
naphthalen-2-yl(phenyl)methanone (3k)

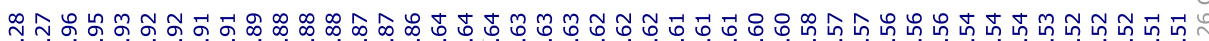

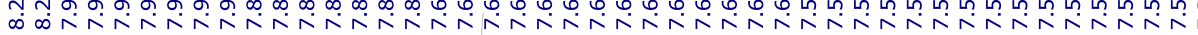<smiles>O=C(c1ccccc1)c1ccc2ccccc2c1</smiles>

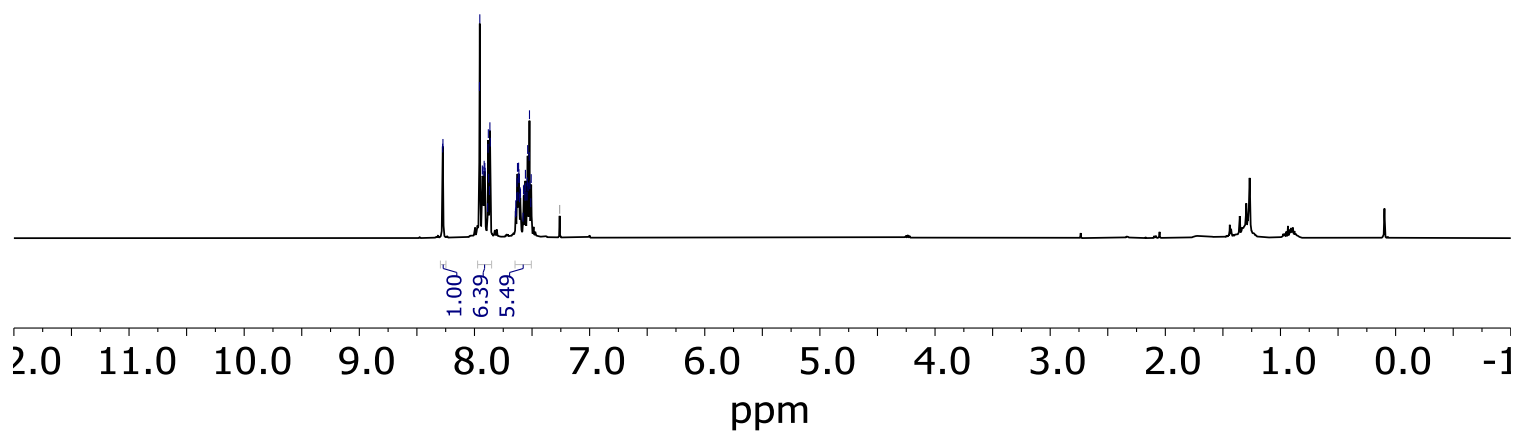

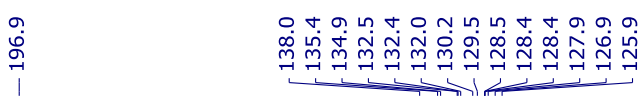<smiles>O=C(c1ccccc1)c1ccc2ccccc2c1</smiles>

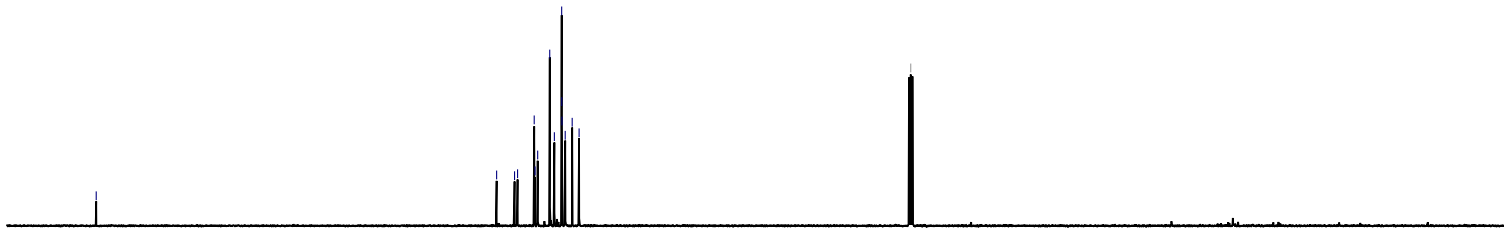

\begin{tabular}{llllllllllll}
\hline 10 & 190 & 170 & 150 & 130 & $\begin{array}{c}110 \\
\mathrm{ppm}\end{array}$ & 90 & 70 & 50 & 30 & 10 & $-:$
\end{tabular}



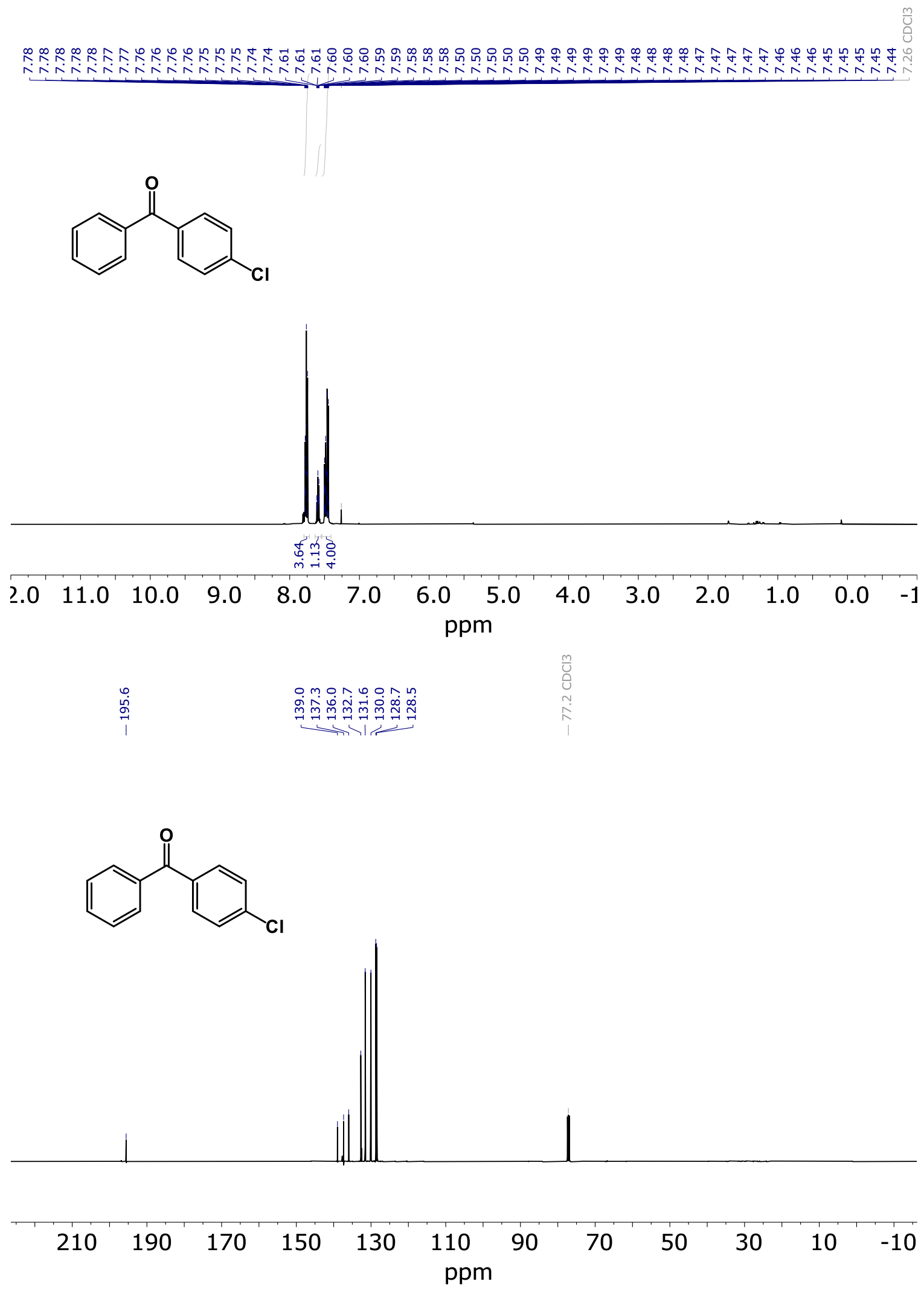
phenyl(4-(trifluoromethyl)phenyl)methanone (3m)

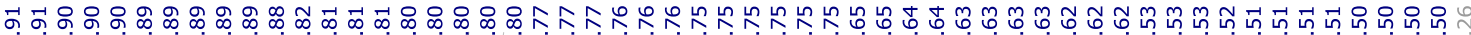

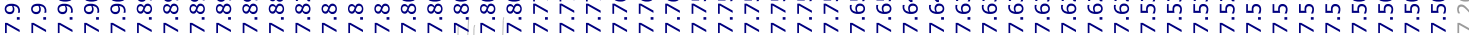<smiles>O=C(c1ccccc1)c1ccc(C(F)(F)F)cc1</smiles>

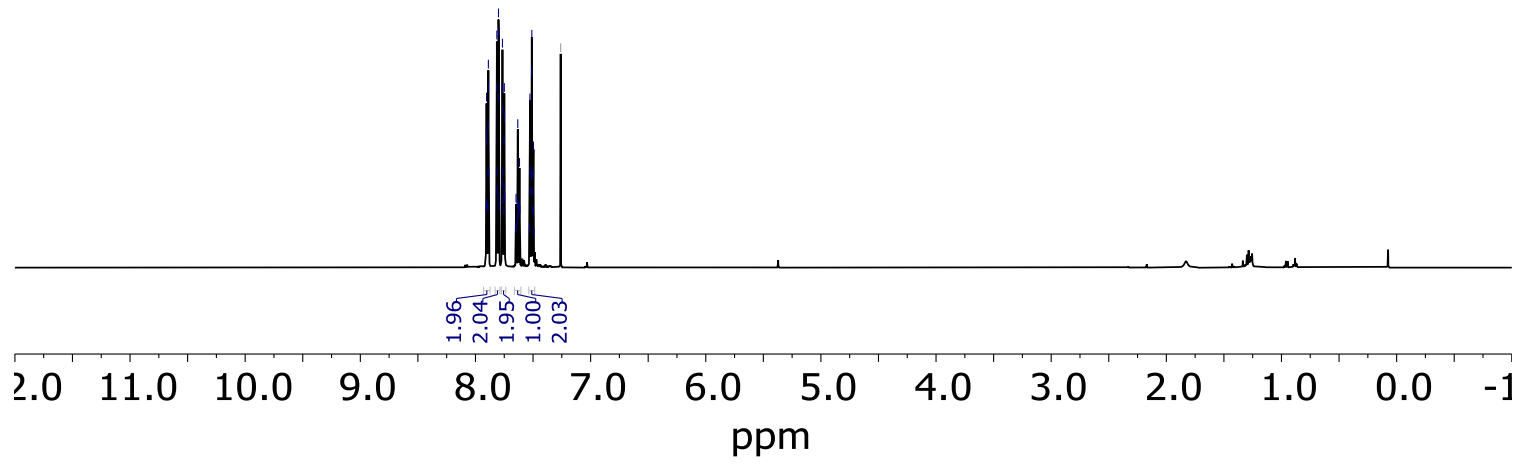

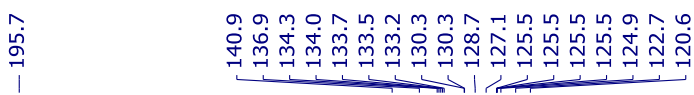<smiles>O=C(c1ccccc1)c1ccc(C(F)(F)F)cc1</smiles>

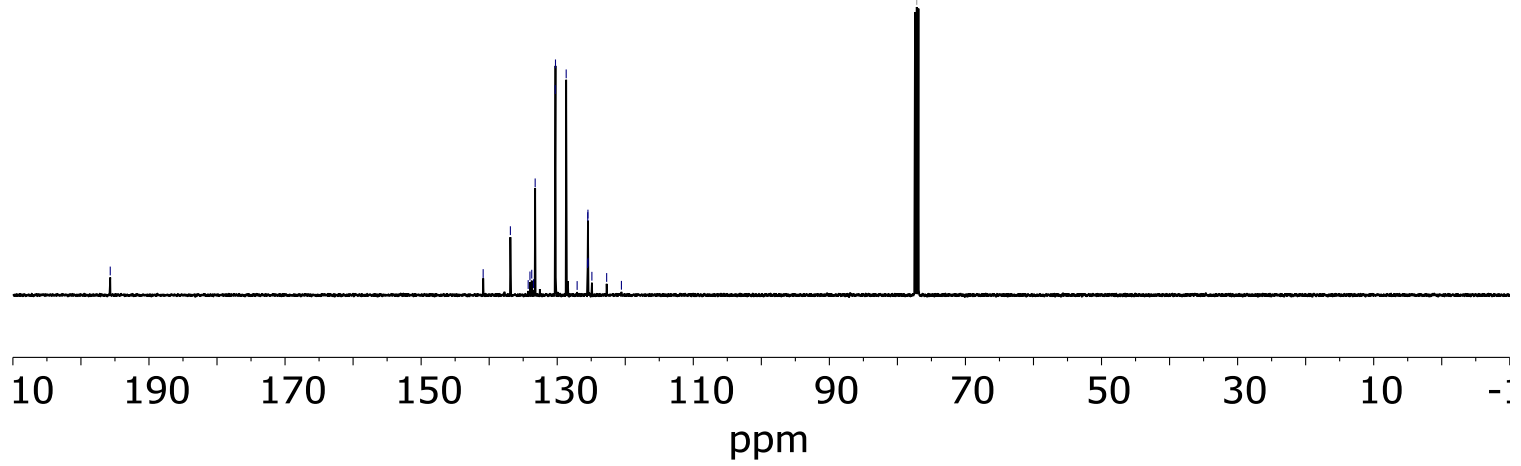




\section{6-benzoyl-2,3-dihydro-1H-inden-1-one (3n)}

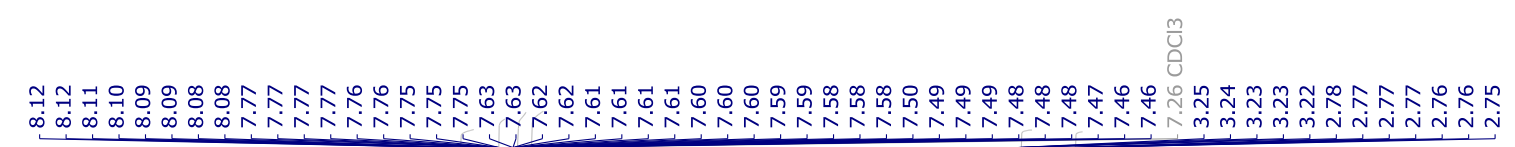<smiles>O=C(c1ccccc1)c1ccc2c(c1)C(=O)CC2</smiles>
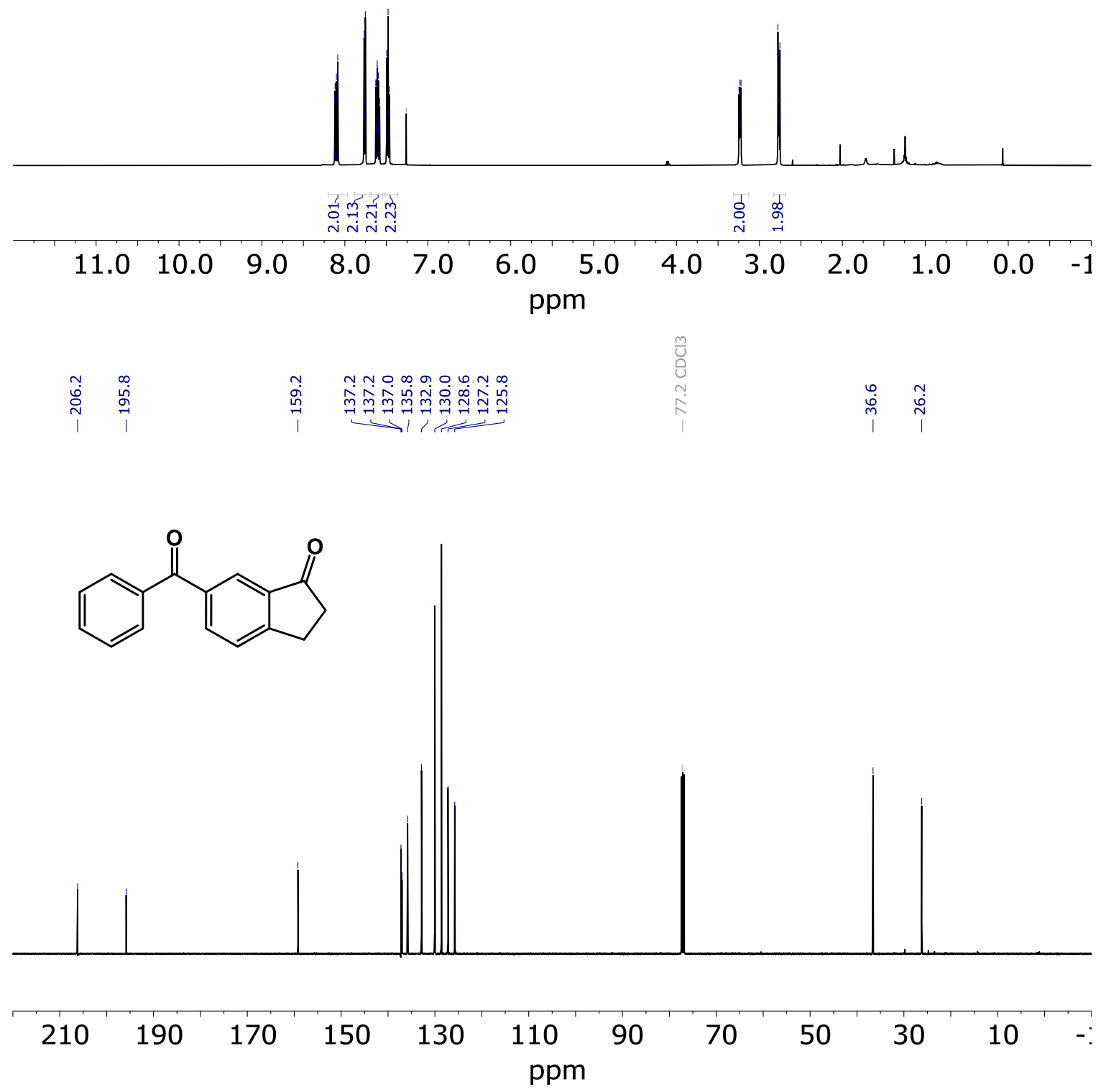
benzo[b]thiophen-5-yl(phenyl)methanone (3o)

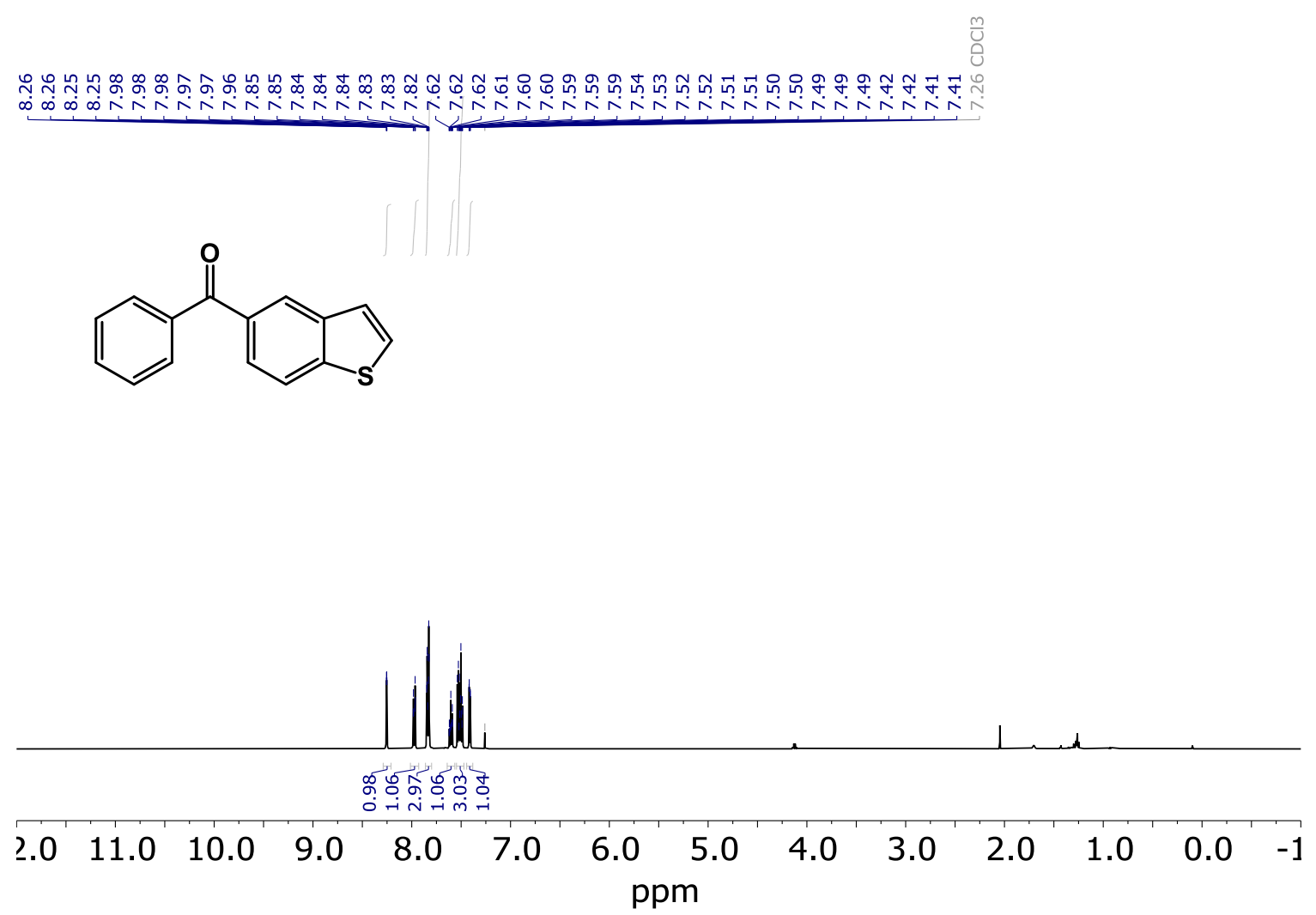

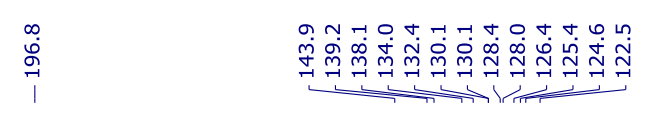

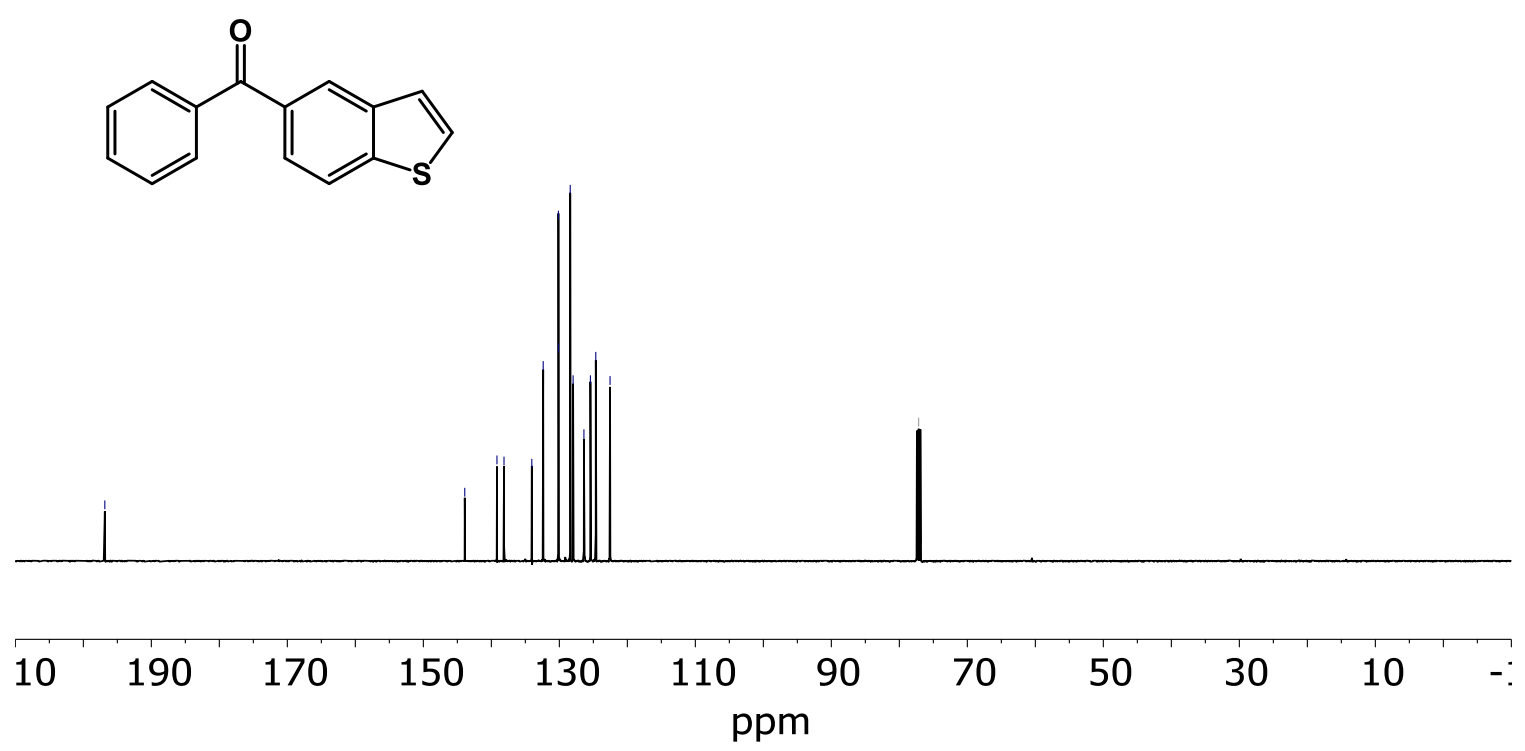




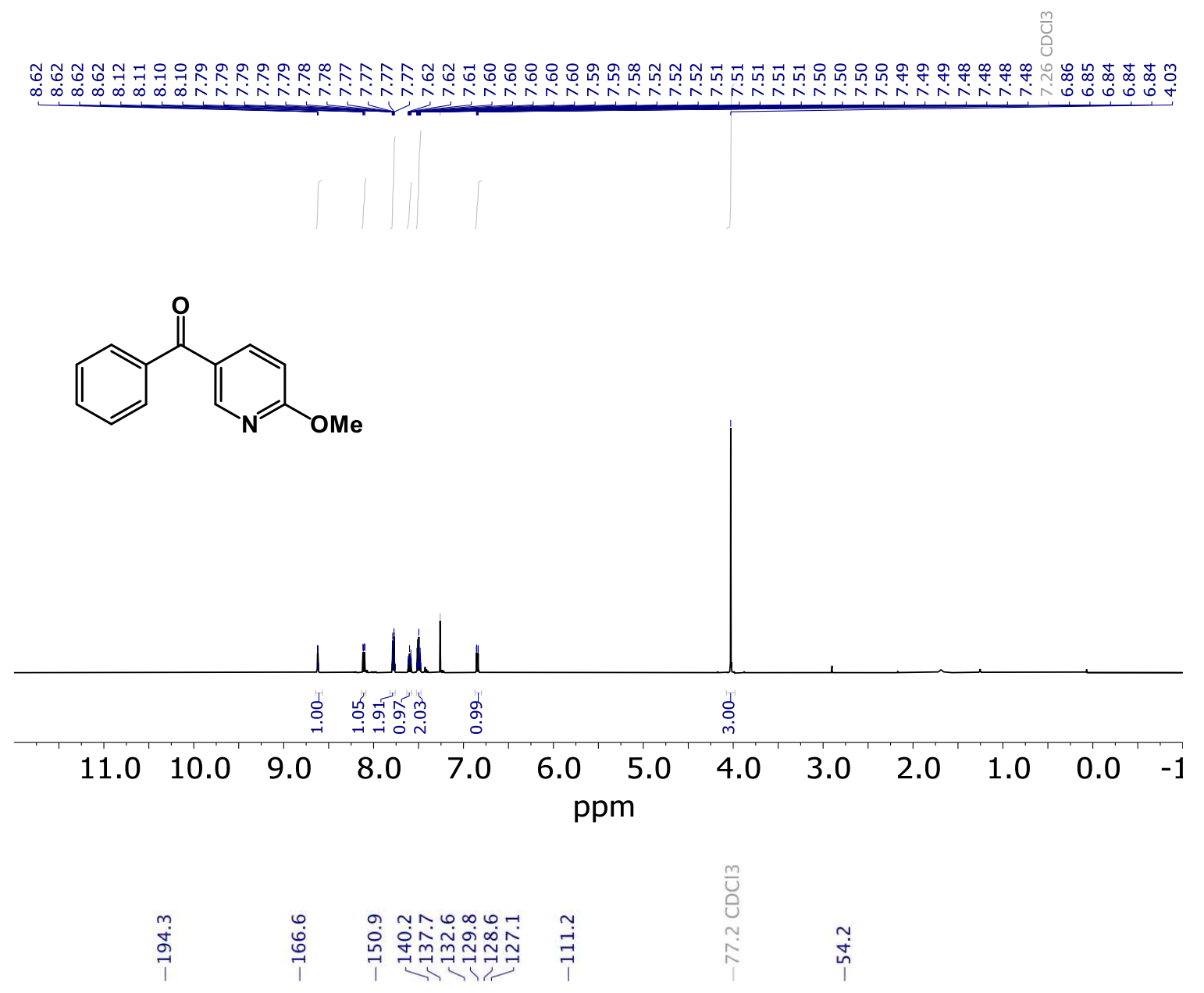<smiles>COc1ccc(C(=O)c2ccccc2)cn1</smiles>

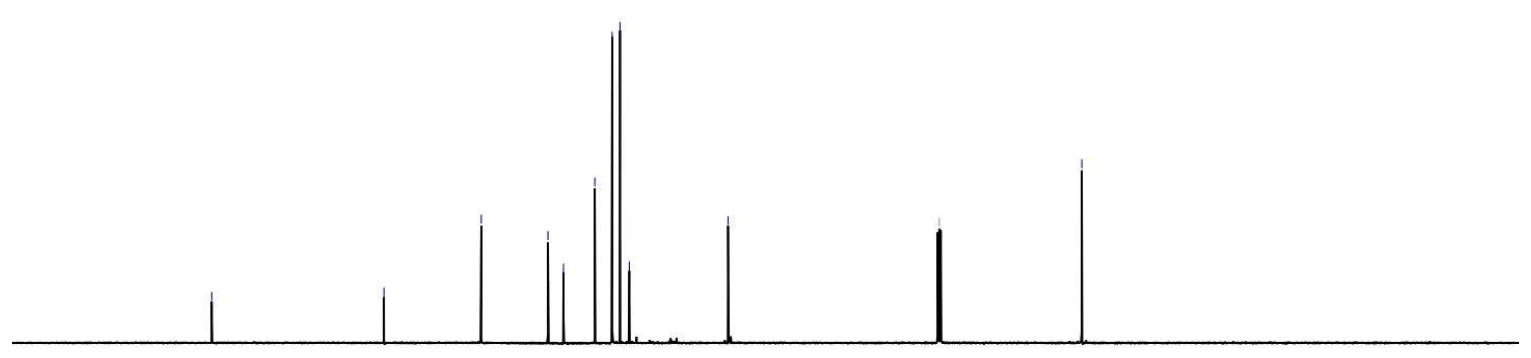

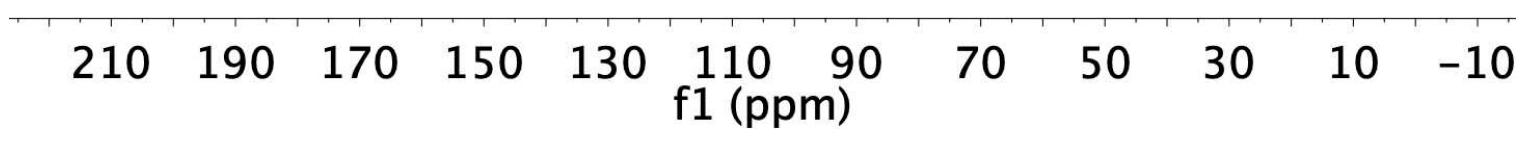


(4-fluorophenyl)(4-methoxyphenyl)methanone (3s)

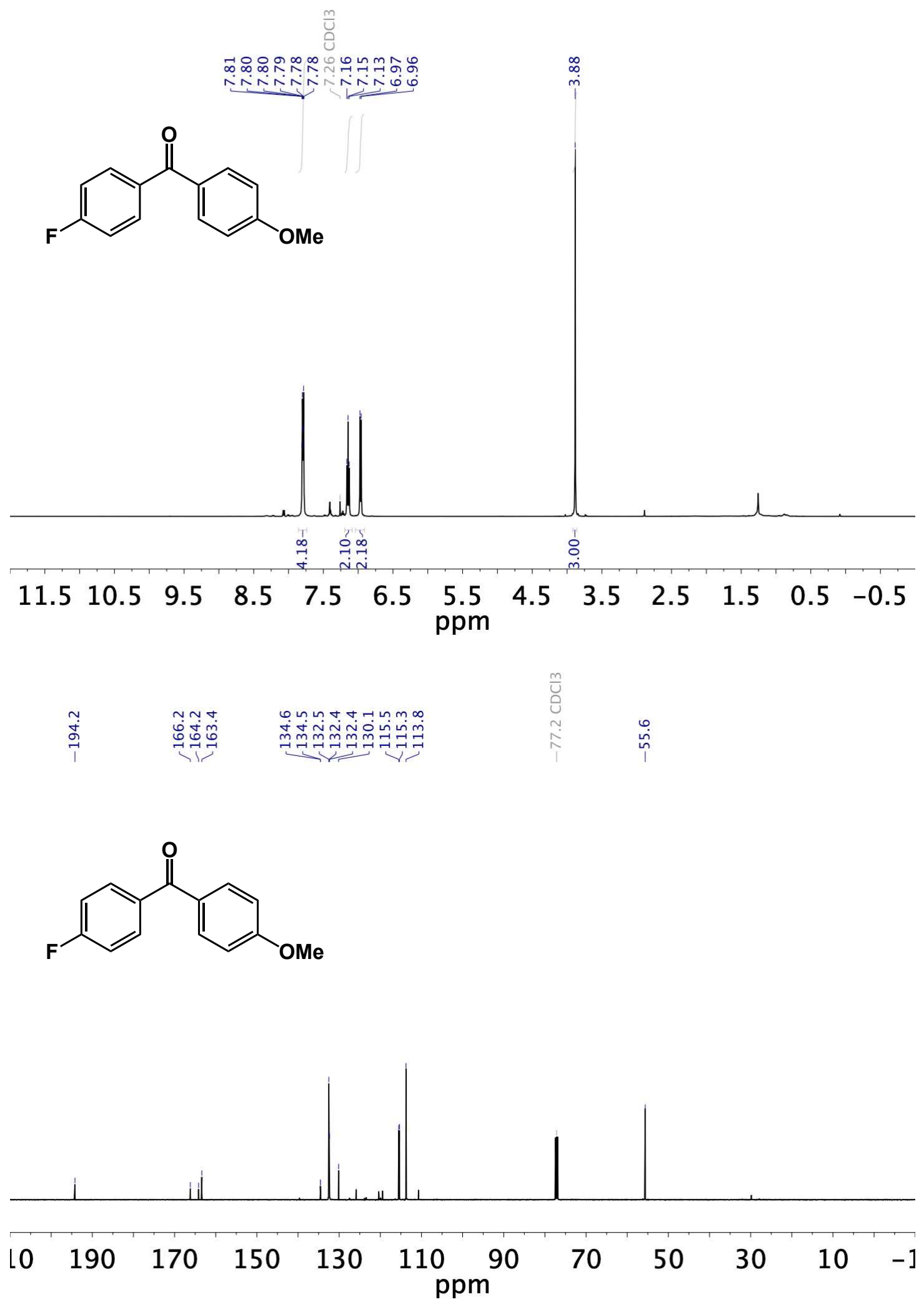




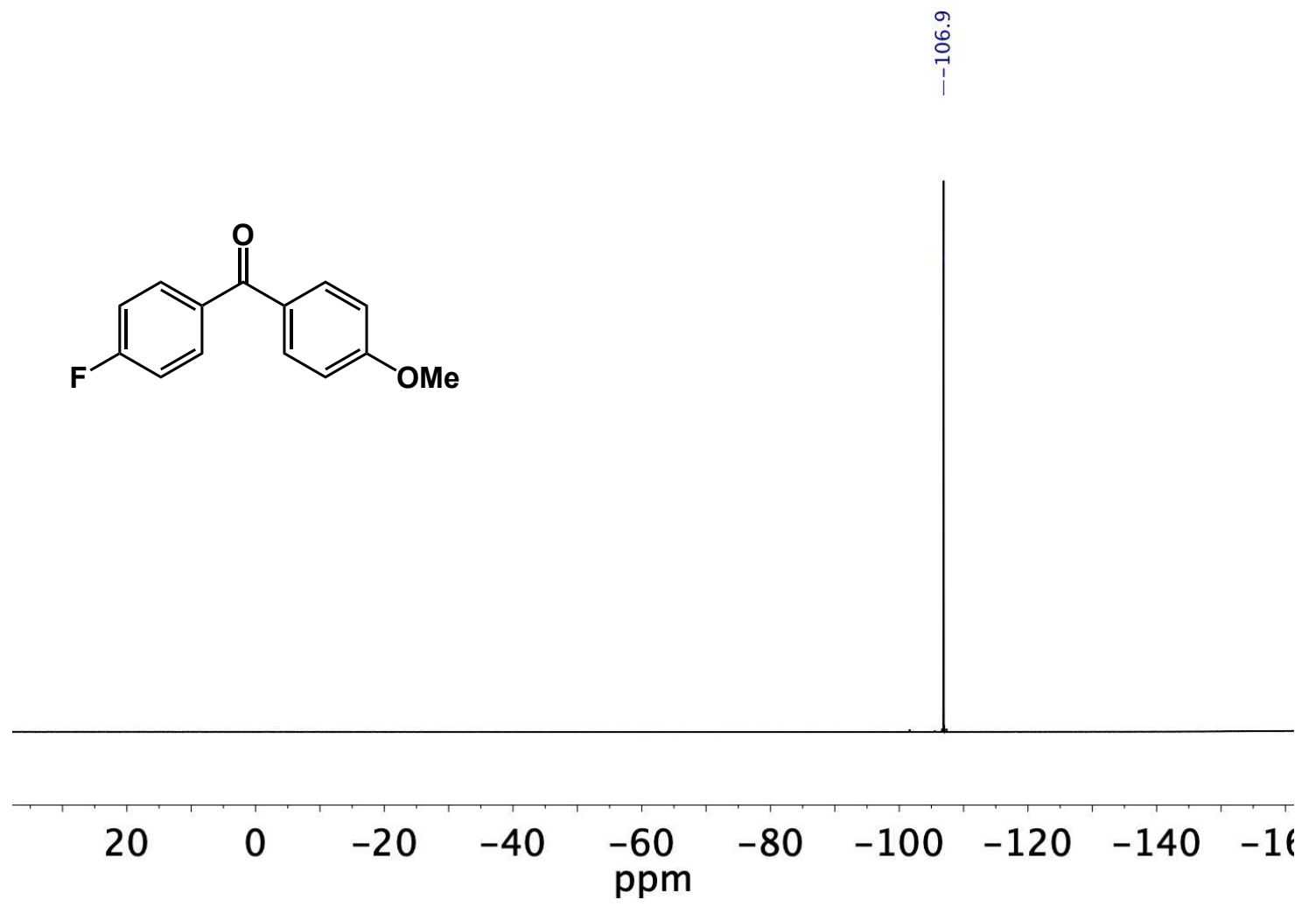


(4-(dimethylamino)phenyl)(4-fluorophenyl)methanone (3t)<smiles>CN(C)c1ccc(C(=O)c2ccc(F)cc2)cc1</smiles>
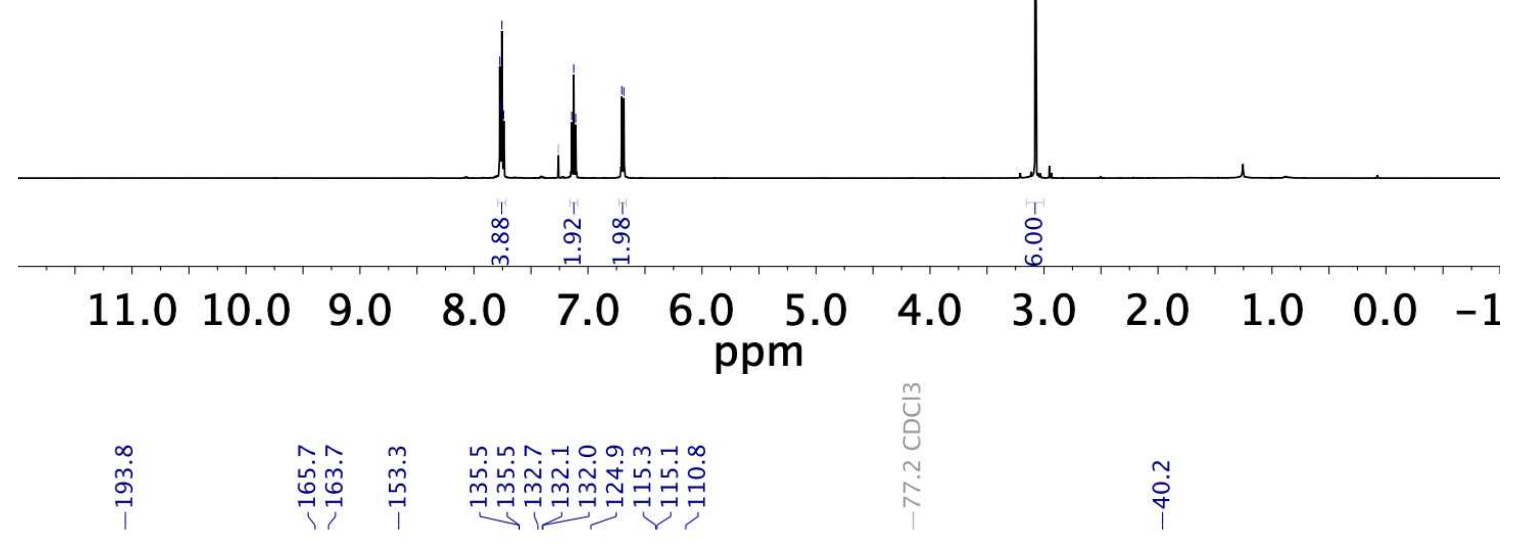<smiles>CN(C)c1ccc(C(=O)c2ccc(F)cc2)cc1</smiles>

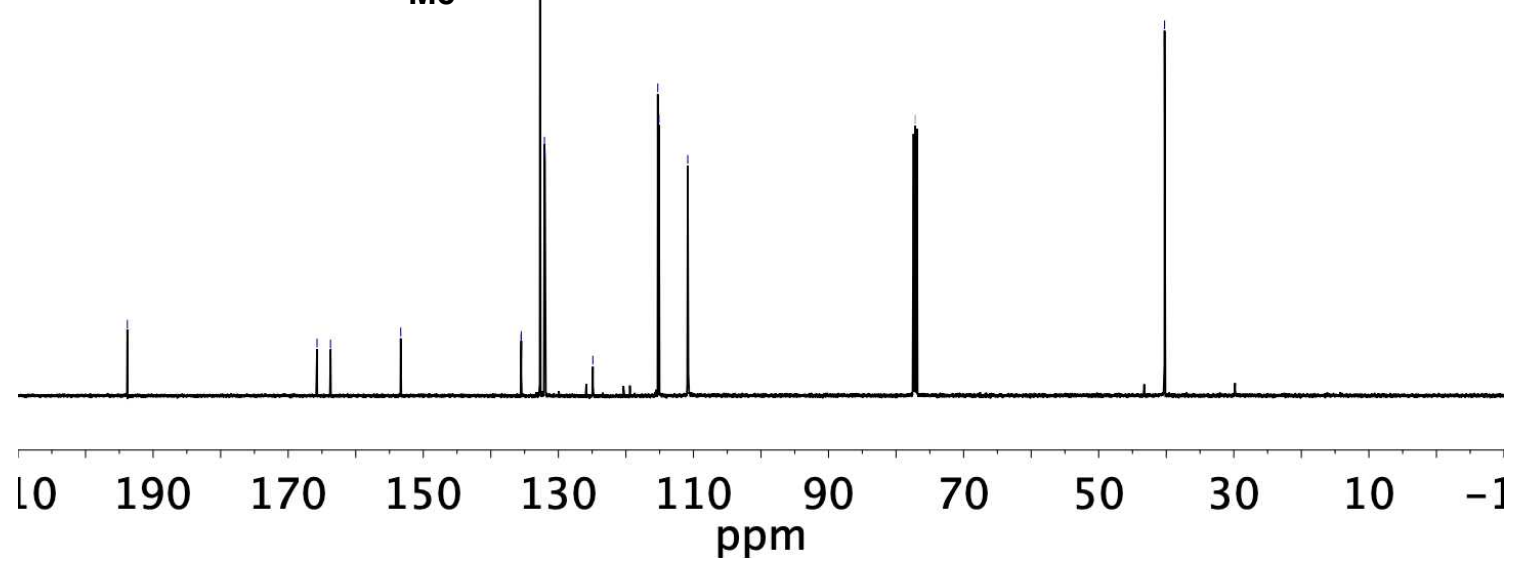


<smiles>CN(C)c1ccc(C(=O)c2ccc(F)cc2)cc1</smiles>

\section{$\begin{array}{llllllllll}150 & 110 & 70 & 30 & -10 & -50 & -90 & -130 & -170 & -21\end{array}$ ppm}


bis(4-methoxyphenyl)methanone (3u)
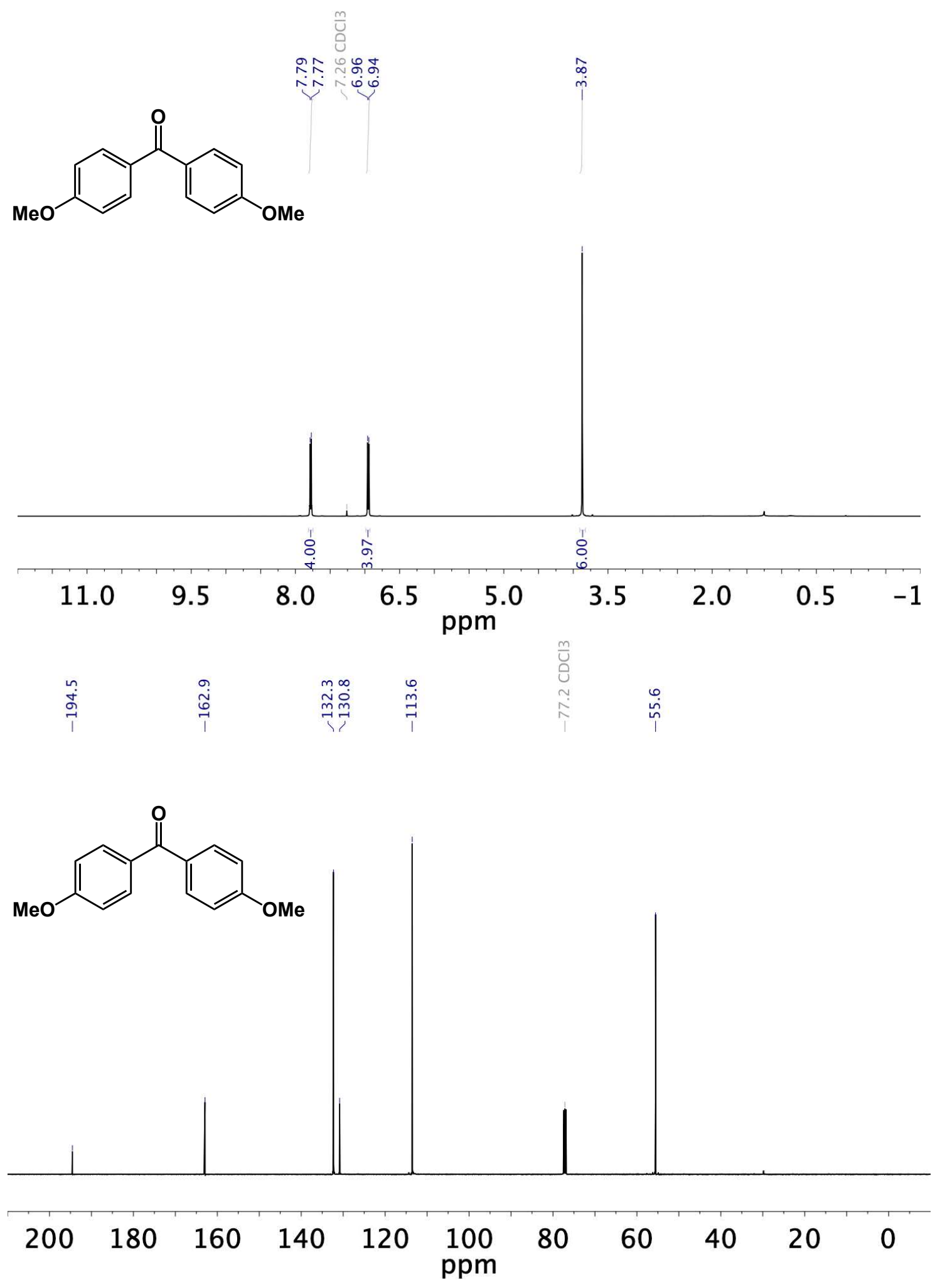
(4-(dimethylamino)phenyl)(4-methoxyphenyl)methanone (3v)
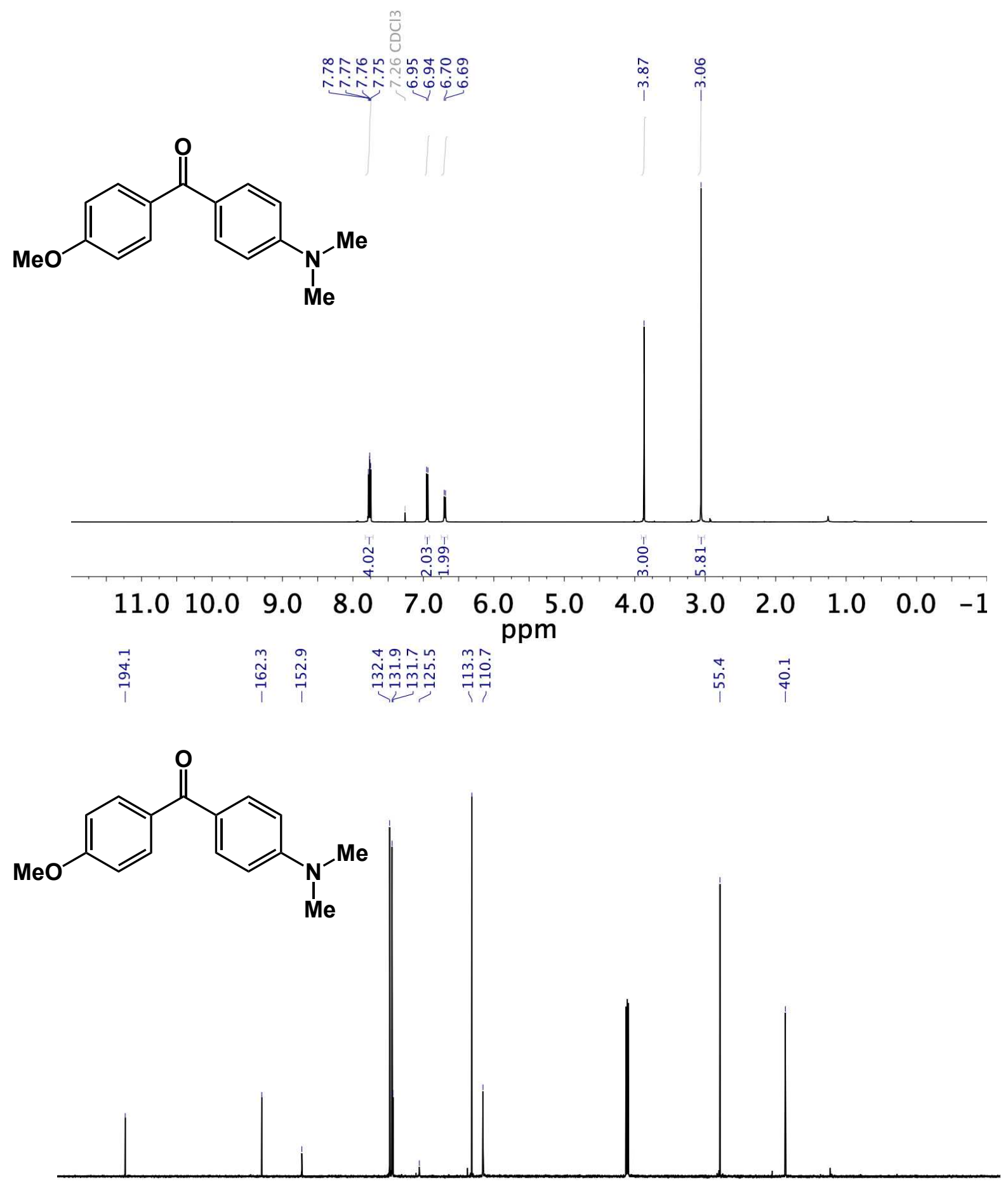

$\begin{array}{lllllllllll}200 & 180 & 160 & 140 & 120 & \begin{array}{l}100 \\ \mathrm{ppm}\end{array} & 80 & 60 & 40 & 20 & 0\end{array}$


4-methoxyacetophenone (3w)
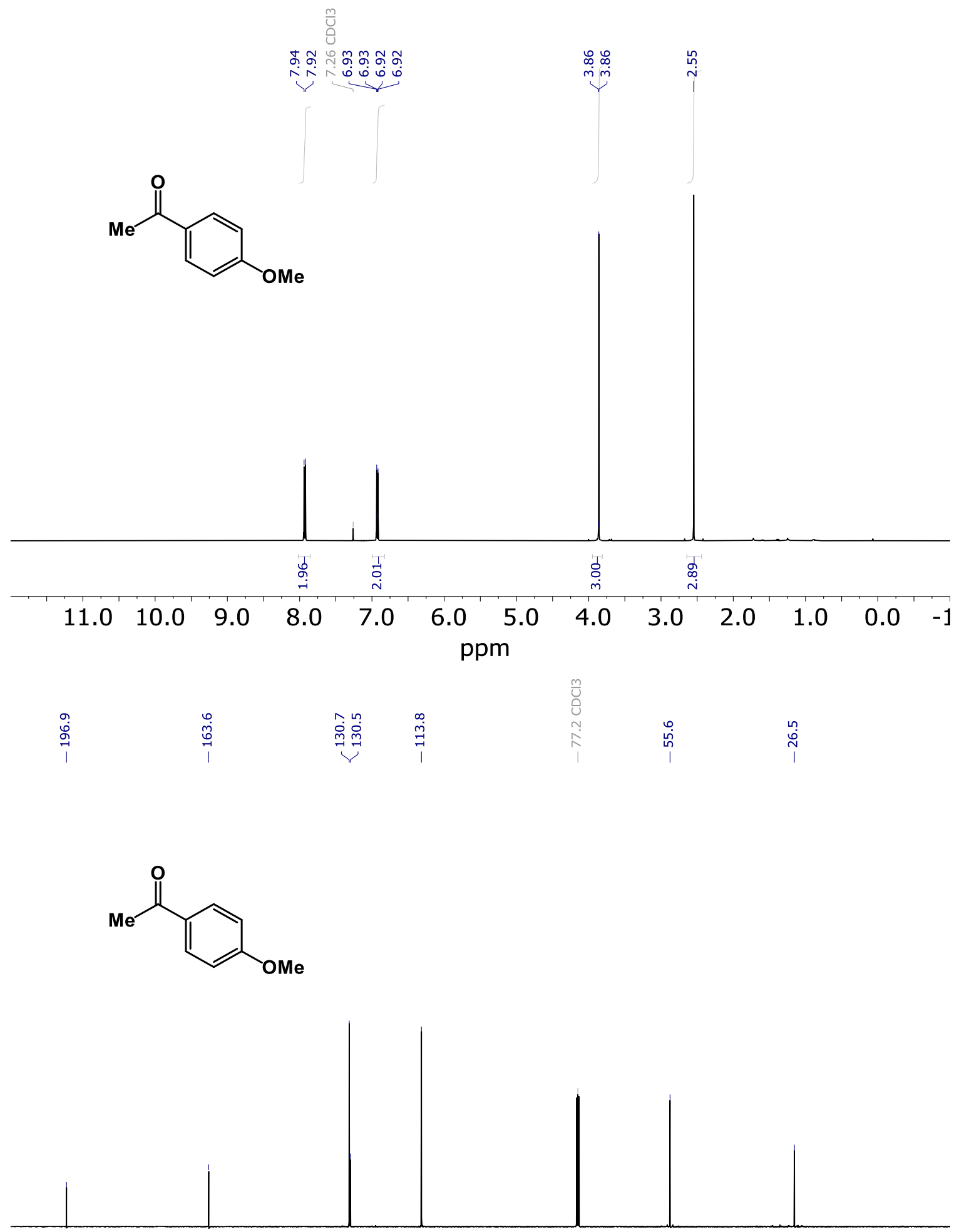

\begin{tabular}{cccccccccccc}
\hline 10 & 190 & 170 & 150 & 130 & 110 & 90 & 70 & 50 & 30 & 10 & $-:$
\end{tabular}




\section{4-dimethylaminoacetophenone (3x)}

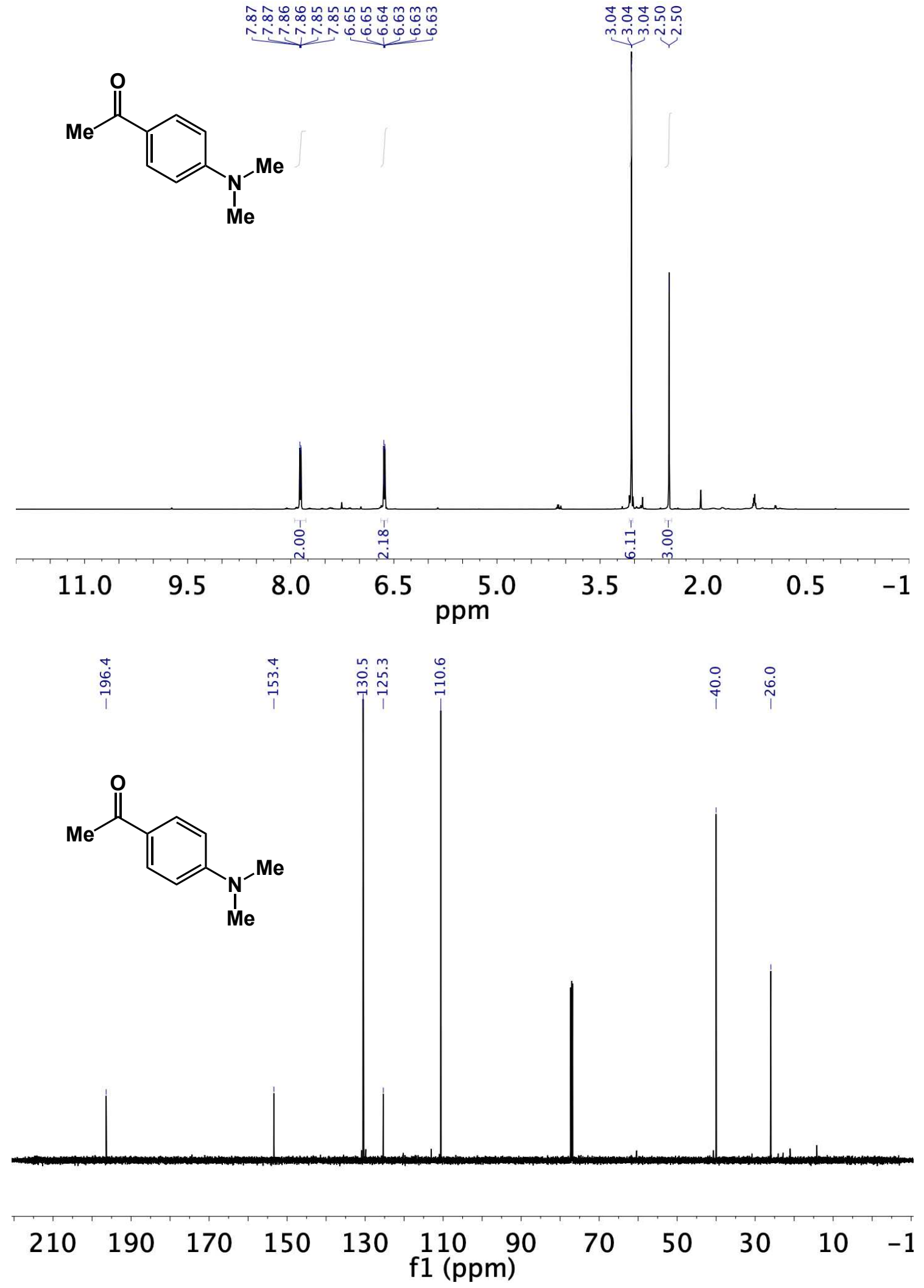


cyclohexyl(4-methoxyphenyl)methanone (3y)

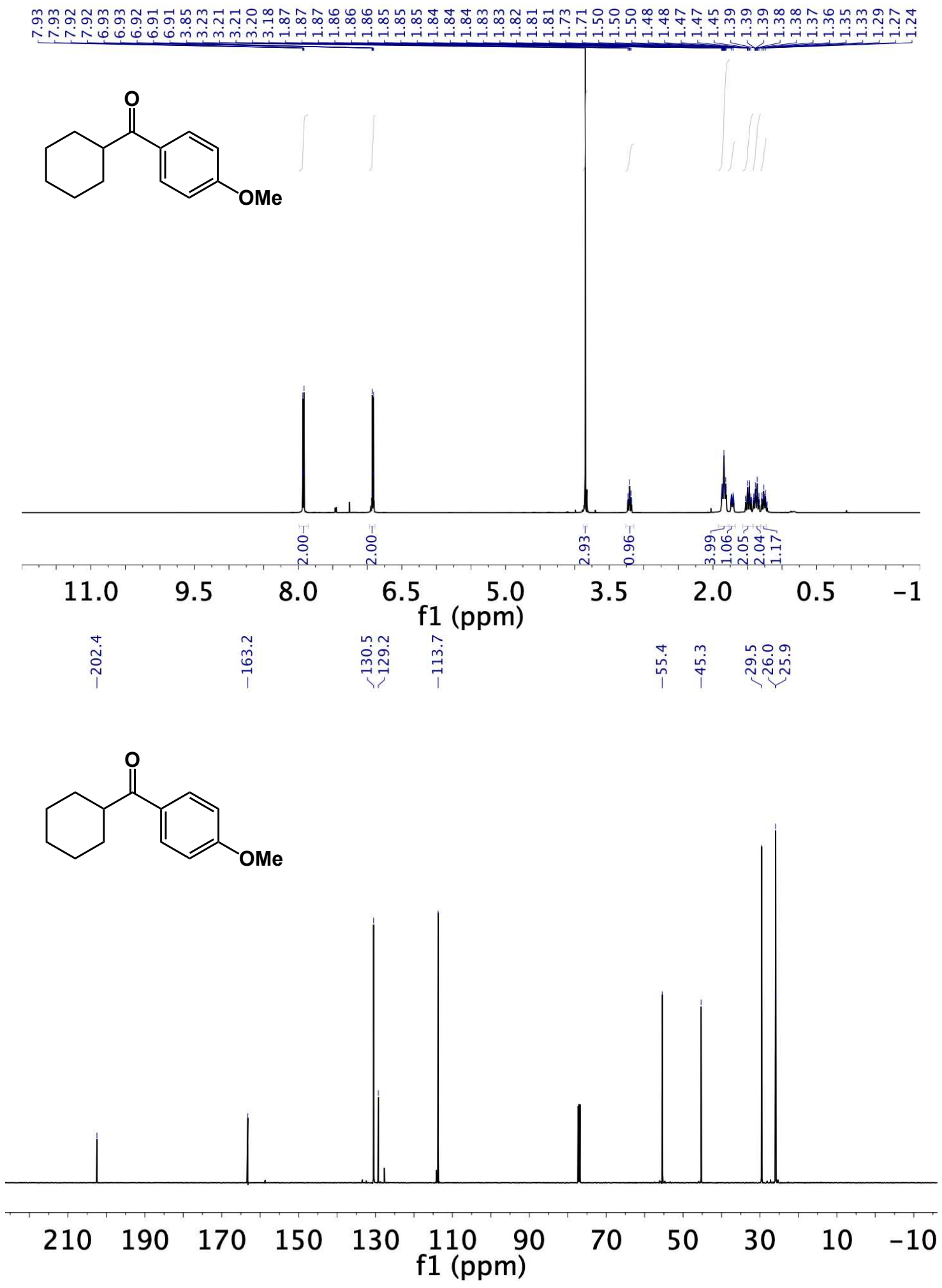


1-(4-methoxyphenyl)-3-phenylpropan-1-one (3z)

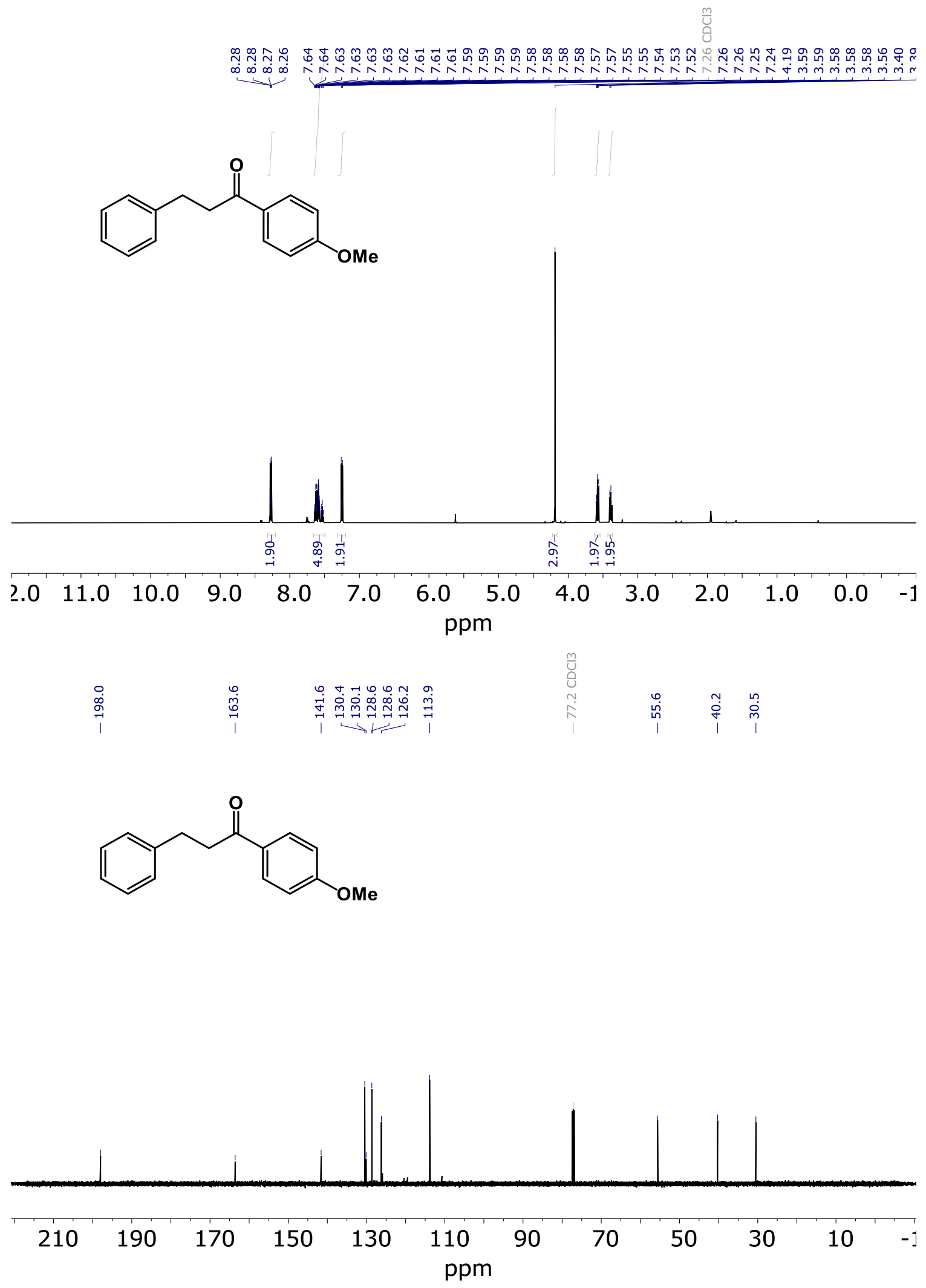


1-(4-(dimethylamino)phenyl)-3-phenylpropan-1-one (3aa)

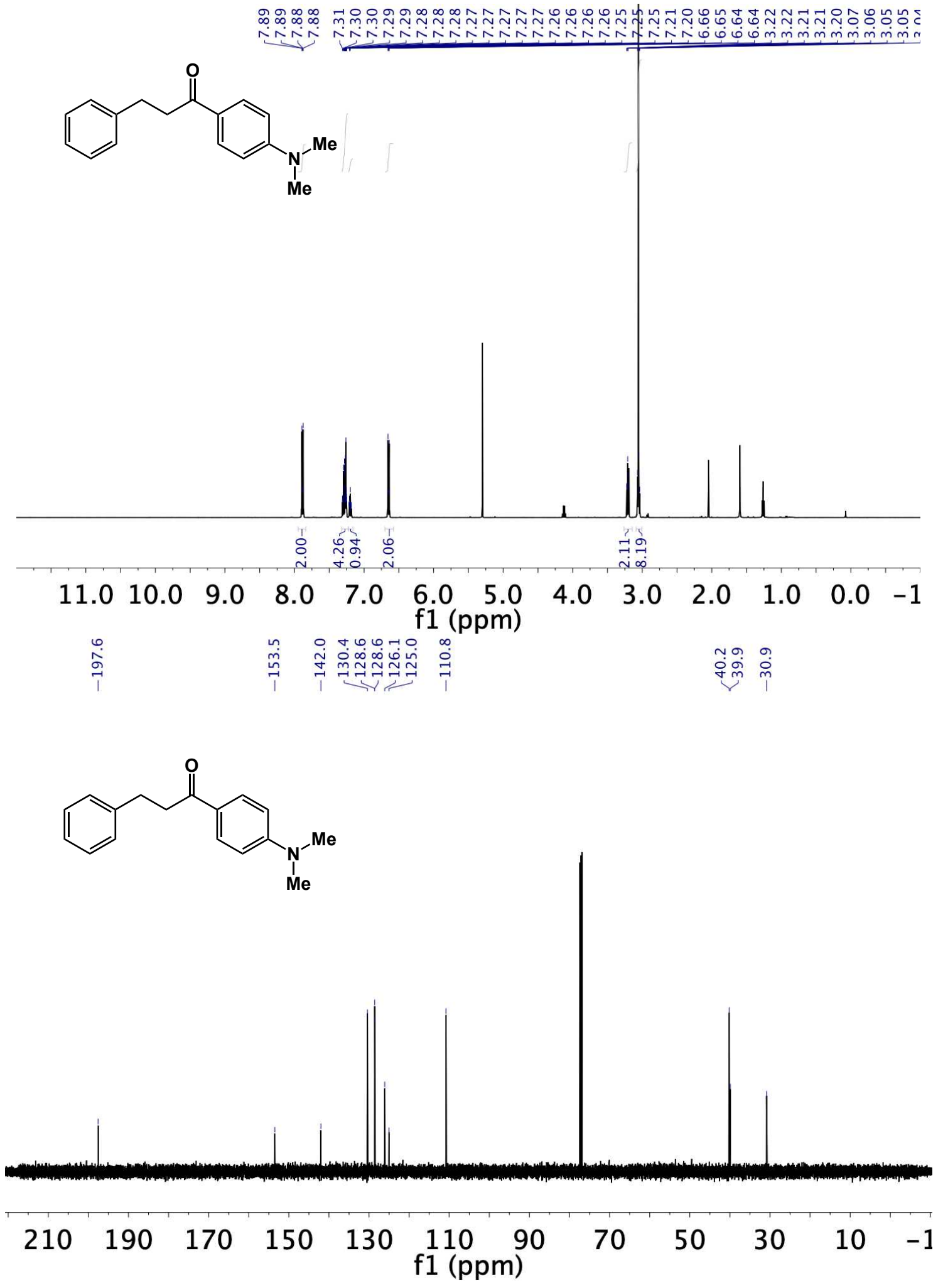

